DOC.20041005.0004

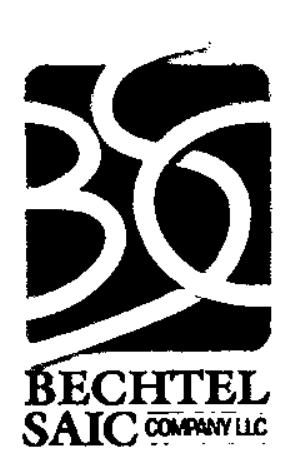

QA: QA

ANL-NBS-HS-000042 REV 00

October 2004

\title{
Analysis of Hydrologic Properties Data
}

Prepared for:

U.S. Department of Energy

Office of Civilian Radioactive Waste Management

Office of Repository Development

1551 Hillshire Drive

Las Vegas, Nevada 89134-6321

Prepared by:

Bechtel SAIC Company, LLC

1180 Town Center Drive

Las Vegas, Nevada 89144

Under Contract Number

DE-AC28-01RW12101 


\section{DISCLAIMER}

This report was prepared as an account of work sponsored by an agency of the United States Government. Neither the United States Government nor any agency thereof, nor any of their employees, nor any of their contractors, subcontractors or their employees, makes any warranty, express or implied, or assumes any legal liability or responsibility for the accuracy, completeness, or any third party's use or the results of such use of any information, apparatus, product, or process disclosed, or represents that its use would not infringe privately owned rights. Reference herein to any specific commercial product, process, or service by trade name, trademark, manufacturer, or otherwise, does not necessarily constitute or imply its endorsement, recommendation, or favoring by the United States Government or any agency thereof or its contractors or subcontractors. The views and opinions of authors expressed herein do not necessarily state or reflect those of the United States Government or any agency thereof. 
QA: QA

Analysis of Hydrologic Properties Data ANL-NBS-HS-000042 REV 00

October 2004 


\section{Scientific Analyzis Thue}

Analysis of Hydrologic Properries Data

\section{Di (nduding Rovision Number) \\ ANL-NBS-HS-000042 REV 00}

\begin{tabular}{|c|c|c|c|}
\hline $\begin{array}{l}\text { 4. Total Appondices } \\
\text { One }\end{array}$ & & $\begin{array}{l}\text { 5. Number of Pages in Each Appendix } \\
\text { A - } 28\end{array}$ & \\
\hline 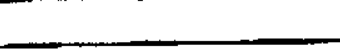 & Printed Name & Signature & Date \\
\hline 6. Originator & L. Pan & & \\
\hline 7. Checker & P. CookdG. La & & \\
\hline 8. QER & P. Buenviaje & & \\
\hline 9. Responsibla Manager/Lead & H.H. LforY-S. Wu & & \\
\hline 10. Responsible Manager & M. Zho & & \\
\hline
\end{tabular}

Block 6. H.H. Lin contributed to Section 6 ,

Change History

\begin{tabular}{|c|c|}
\hline 12. Revision No. & 13. Description of Change \\
\hline REV 00 & 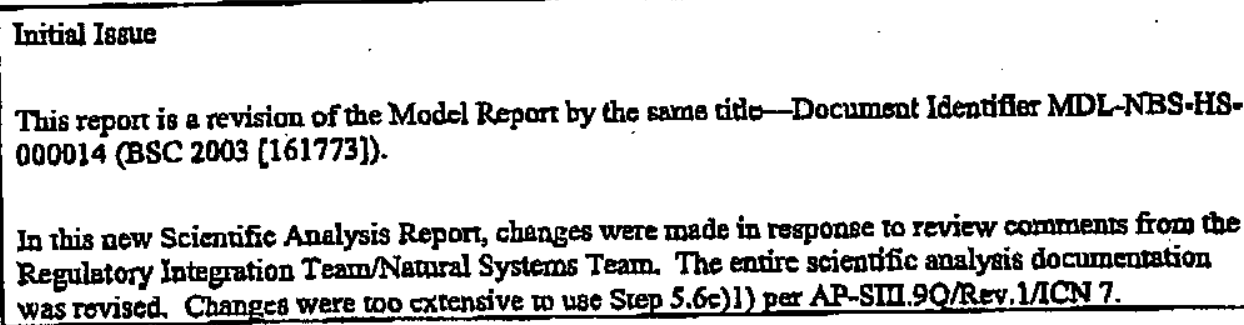 \\
\hline
\end{tabular}




\section{CONTENTS}

Page

ACRONYMS AND ABBREVIATIONS ....................................................................... xi

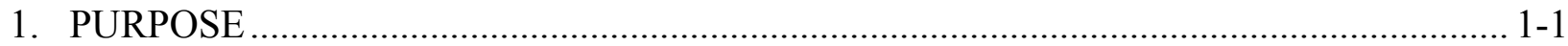

2. QUALITY ASSURANCE ............................................................................... 2-1

3. USE OF SOFTWARE ..................................................................................... $3-1$

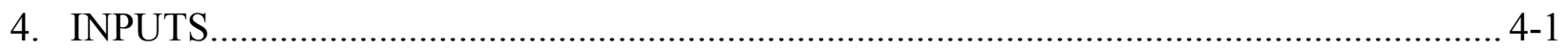

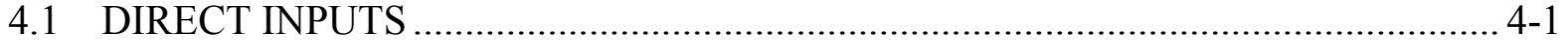

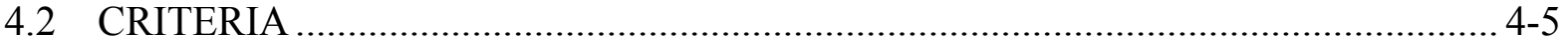

4.3 CODES, STANDARDS, AND REGULATIONS ................................................ 4-6

5. ASSUMPTIONS ......................................................................................................... $5-1$

6. SCIENTIFIC ANALYSIS DISCUSSION .............................................................. $6-1$

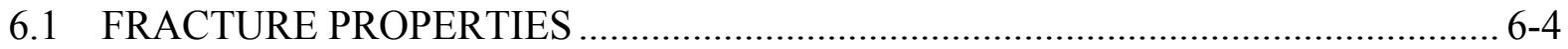

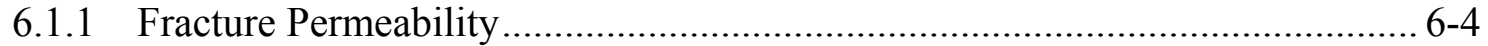

6.1.1.1 Scaling Issues ......................................................................... 6-9

6.1.2 Fracture Frequency, Intensity, Interface Area, Aperture, and van

Genuchten Parameters ............................................................................ 6-10

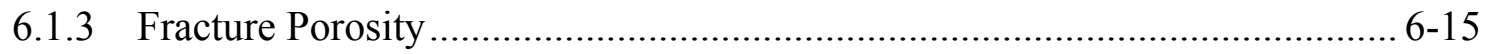

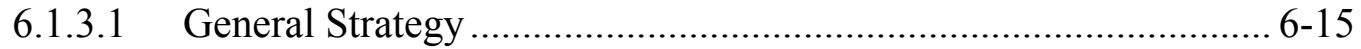

6.1.3.2 Fracture Porosity from Gas Tracer Testing Data ........................ 6-16

6.1.3.3 Effects of Several Factors on Fracture-Porosity Estimation, Based on Gas-Tracer Testing Data............................................ 6-17

6.1.3.4 Comparisons with Fracture Porosities Estimated from Other

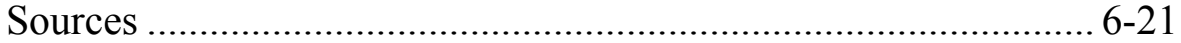



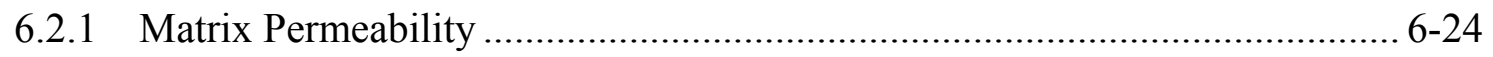

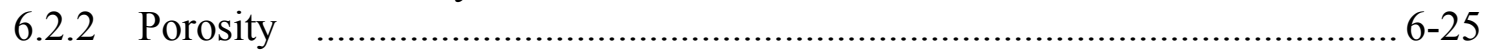

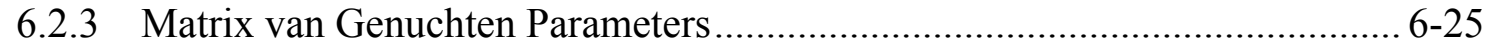

6.2.3.1 Residual Saturation.............................................................. 6-26

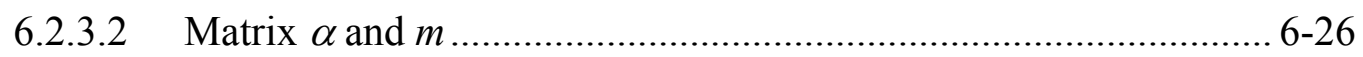

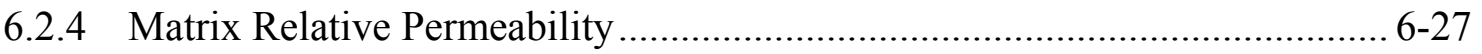

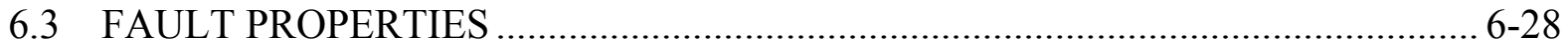

6.4 UNCERTAINTIES, ALTERNATIVE APPROACHES, AND OTHER ISSUES ..... 6-30

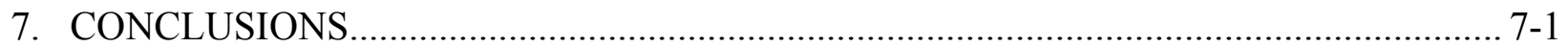

7.1 SUMMARY .............................................................................................. $7-1$

7.2 HOW THE APPLICABLE ACCEPTANCE CRITERIA ARE ADDRESSED .......... 7-1 


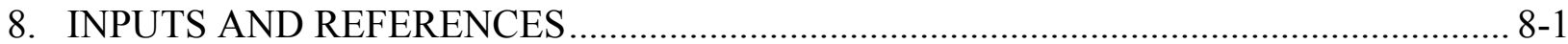

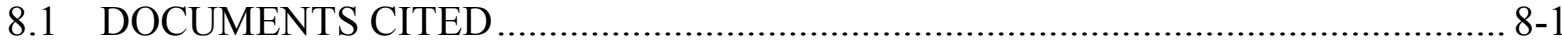

8.2 CODES, STANDARDS, REGULATIONS, AND PROCEDURES ........................ 8-5

8.3 SOURCE DATA, LISTED BY DATA TRACKING NUMBER ............................... 8-6

8.4 OUTPUT DATA, LISTED BY DATA TRACKING NUMBER ........................... 8-11

8.5 SOFTWARE CODES .................................................................................. 8 8 - 11

APPENDIX A - DESCRIPTION OF EXCEL FILES USED ........................................... A-1 


\section{FIGURES}

Page

6-1. Schematic Showing Locations of Selected Boreholes ................................................... 6-6

6-2. Fracture Permeabilities for Topopah Spring Middle Nonlithophysal Unit ..................... 6-10

6-3. A Conceptual Model for Estimating Fracture Porosity Using Gas-Tracer Testing Data...... 


\section{INTENTIONALLY LEFT BLANK}




\section{TABLES}

Page

4-1. Data Tracking Numbers for Input Data Used.......................................................... 4-3

4-2. Acceptance Criteria Applicable to This Analysis Report ............................................... 4-5

6-1. Correlation of GFM2000 Lithostratigraphy, UZ Model Layer, and Hydrogeologic

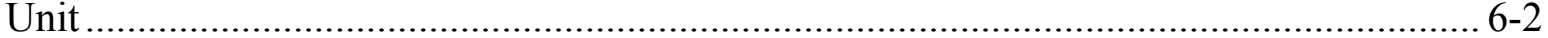

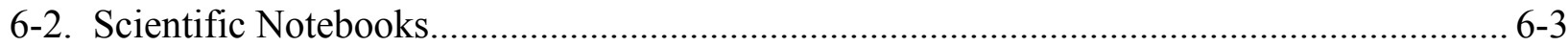

6-3. FEPs Addressed in this Analysis Report ....................................................................... 6-4

6-4. Uncalibrated Fracture Permeabilities for the UZ Model Layers .................................... 6-7

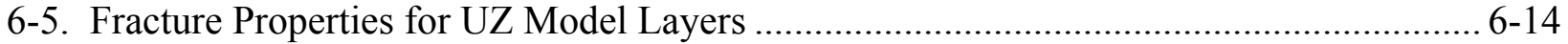

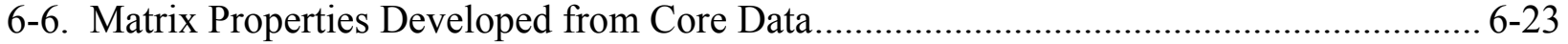

6-7. Calculated Fault Fracture Properties ........................................................................... 6-30 


\section{INTENTIONALLY LEFT BLANK}




\section{ACRONYMS AND ABBREVIATIONS}

\begin{tabular}{|c|c|}
\hline AMR & analysis and modeling report \\
\hline $\mathrm{CFu}$ & Crater Flat undifferentiated hydrogeologic unit \\
\hline $\mathrm{CHn}$ & Calico Hills nonwelded hydrogeologic unit \\
\hline DLS & detailed line survey \\
\hline DST & Drift Scale Test \\
\hline ECRB & Enhanced Characterization of Repository Block \\
\hline ESF & Exploratory Studies Facility \\
\hline FEP & feature, event, and process \\
\hline $\mathrm{HGU}$ & hydrogeologic unit \\
\hline PTn & Paintbrush nonwelded hydrogeologic unit \\
\hline QA & Quality Assurance \\
\hline $\mathrm{RH}$ & relative humidity \\
\hline $\mathrm{TCw}$ & Tiva Canyon welded hydrogeologic unit \\
\hline TDMS & Technical Data Management System \\
\hline TPO & technical product output \\
\hline TSPA & total system performance assessment \\
\hline TSw & Topopah Spring welded hydrogeologic unit \\
\hline TWP & technical work plan \\
\hline $\mathrm{UZ}$ & unsaturated zone \\
\hline YMRP & Yucca Mountain Review Plan \\
\hline
\end{tabular}




\section{INTENTIONALLY LEFT BLANK}




\section{PURPOSE}

This analysis report describes the methods used to determine hydrologic properties based on the available field data from the unsaturated zone (UZ) at Yucca Mountain, Nevada. The technical scope, content, and management of this analysis report are described in the planning document Technical Work Plan for: Unsaturated Zone Flow Analysis and Model Report Integration (BSC 2004 [DIRS 169654], Sections 2, 4, and 8). Fracture and matrix properties are developed by analyzing available survey data from the Exploratory Studies Facility (ESF), the Enhanced Characterization of Repository Block (ECRB) Cross-Drift, and/or boreholes; air-injection testing data from surface boreholes and from boreholes in the ESF; and data from laboratory testing of core samples. In addition, the report Geologic Framework Model (GFM2000) (BSC 2004 [DIRS 170029]) also serves as a source report by providing the geological framework model of the site. This report is a revision of the model report under the same title (BSC 2003 [DIRS 161773]), which in turn superceded the analysis report under the same title (BSC 2001 [DIRS 159725]).

The principal purpose of this work is to provide representative uncalibrated estimates of fracture and matrix properties for use in the model report Calibrated Properties Model. The term "uncalibrated" is used to distingush the properties or parameters estimated in this report from those obtained from the inversion modeling used in Calibrated Properties Model. The present work also provides fracture geometry properties for generating dual-permeability grids as documented in the scientific analyses report, Development of Numerical Grids for UZ Flow and Transport Modeling.

The following reports also use the output (hydrologic properties of tuffs) of this report as direct input:

- Multiscale Thermohydrologic Model

- Drift-Scale THC Seepage Model

- Seepage Calibration Model and Seepage Testing Data

- UZ Flow Models and Submodels

- Mountain-Scale Coupled Processes

- Drift-Scale Radionuclide Transport

- Drift Scale THM Model

- Particle Tracking Model and Abstraction of Transport Process.

The fracture, matrix, and fault properties developed in this report include:

- Fracture properties (frequency, permeability, van Genuchten $\alpha$ and $m$ parameters, aperture, porosity, and interface area) for each UZ Model layer

- Matrix properties (porosity, permeability, and van Genuchten $\alpha$ and $m$ parameters) for each UZ Model layer

- Fault properties for each major hydrogeologic unit (TCw, $\mathrm{PTn}, \mathrm{TSw}$, and $\mathrm{CHn} / \mathrm{CFu}$, as defined in Table 6-1). 
These properties incorporate the available measurement data, as applicable.

A list of relevant features, events, and processes (FEPs) is presented in Section 6.

Constraints and limitations are as follows: the fracture permeability, van Genuchten fracture $\alpha$ and $m$, matrix permeability, and van Genuchten matrix $\alpha$ and $m$ reported here are not calibrated to the real system, the UZ. The parameters developed in this report are subject to additional uncertainty because of a lack of measured data for certain rock layers. Therefore, they should be used only after careful evaluation. At least some degree of calibration of the numerical model against measured data of a given system is required. In many cases, the values obtained from this report serve as good initial estimates in the Calibrated Properties Model of the UZ. 


\section{QUALITY ASSURANCE}

Development of this analysis report has been determined to be subject to the Yucca Mountain Project's quality assurance (QA) program as indicated in Technical Work Plan for: Unsaturated Zone Flow Analysis and Model Report Integration (BSC 2004 [DIRS 169654], Section 8.1). Approved QA procedures identified in the technical work plan (BSC 2004 [DIRS 169654], Section 4) have been used to conduct and document the activities described in this analysis report. The TWP also identifies the methods used to control the electronic management of data (BSC 2004 [DIRS 169654], Section 8.4) during the modeling and documentation activities.

This analysis report provides uncalibrated values for hydrologic properties of identified natural barriers that are classified in the Q-List (BSC 2004 [DIRS 168361]) as "Safety Category", because they are important to waste isolation, as defined in AP-2.22Q, Classification Analyses and Maintenance of the Q-List. The report contributes to the analysis and modeling data used to support the Total System Performance Assessment (TSPA). The conclusions of this analysis report do not affect the repository design or engineered features important to safety, as defined in AP-2.22Q. 


\section{INTENTIONALLY LEFT BLANK}




\section{USE OF SOFTWARE}

No software is used in this study except for standard Excel spreadsheets and visual display graphics programs (Excel 97 SR-1 and Tecplot V7.0), which are not subject to software quality assurance requirements. All information needed to reproduce the work using these standard software programs is included in this report, with references specified (See Appendix A). Names of files based on these programs are given in Section 6. (Excel files involving computations are specified in Sections 6.1 and 6.2.) A detailed description of these files is presented in Appendix A. 


\section{INTENTIONALLY LEFT BLANK}




\section{INPUTS}

Fracture properties are developed based on available fracture survey data from the ESF, ECRB Cross-Drift, and boreholes and air-injection testing data from vertical boreholes and ESF alcoves. Matrix properties are determined by combining core and small-scale matrix property data. Properties are determined by computing means, standard deviations, and standard errors for each UZ Model layer (BSC 2004 [DIRS 169855]) for each property. Fracture porosities are determined based on the analyses of gas tracer data from the ESF. When no data for a specific layer are available, analogs are identified and used to assign properties. The data used in this report are appropriate for this study because they are site-specific data from the UZ at Yucca Mountain. The appropriateness of the data is also discussed in Section 6 when they are used for developing UZ properties.

\subsection{DIRECT INPUTS}

The input data used in property-set development include the following:

- Previously developed fracture properties (i.e., Fracture frequency, interface area, and the van Genuchten $\mathrm{m}$ ) based on the fracture data (including spatially varying frequency, length, dips, and strikes) from the detailed line survey (DLS) along drifts and the fracture frequency data from boreholes (DTN: LB990501233129.001 [DIRS 106787]). This data set is the technical product output (TPO) of a superseded document [historical TPO, Analysis of Hydrologic Properties Data (BSC 2001 [DIRS 159725])]. The use of these fracture property data can be justified as follows (according to the criteria stated in AP-SIII.9Q):

- The source is reliable because (1) the data set was qualified previously; (2) the approaches used to generate these data are defensible and well documented (see Section 6.1.2); and (3) the Input sources to the historical TPO are also qualified. The DTNs of the related input sources to this historical TPO are as follows:

GS960708314224.008 [DIRS 105617]

GS960708314224.010 [DIRS 106031]

GS960808314224.011 [DIRS 106029]

GS960908314224.014 [DIRS 106033]

GS960908314224.018 [DIRS 106067]

GS960908314224.020 [DIRS 106059]

GS970308314222.001 [DIRS 106075]

GS970808314224.008 [DIRS 106049]

GS970808314224.010 [DIRS 106050]

GS970808314224.012 [DIRS 106057]

GS970808314224.014 [DIRS 106069]

GS971108314224.020 [DIRS 105561]

GS971108314224.021 [DIRS 106007]

GS971108314224.022 [DIRS 106009]

GS971108314224.023 [DIRS 106010]

GS971108314224.024 [DIRS 106023] 
GS971108314224.025 [DIRS 106025]

GS971108314224.026 [DIRS 106032]

GS971108314224.028 [DIRS 106047]

GS981108314224.005 [DIRS 109070]

GS990408314224.001 [DIRS 108396]

GS990408314224.002 [DIRS 105625]

TM000000SD12RS.012 [DIRS 105627]

- These data were generated by a highly qualified organization, Lawrence Berkeley National Laboratory.

- These data were used in previous site recommendation documents (e.g., BSC 2004 [DIRS 169855]) and peer-reviewed journal papers (e.g., $\mathrm{Wu}$ et al. 2002 [DIRS 160195]).

- The sole reason for superseding the report is to include new technical content (i.e., the validation activities of the Active Fracture Model).

- Air-injection testing data (from vertical boreholes) used for fracture permeability estimates (DTNs: GS960908312232.013 [DIRS 105574] through LB980120123142.005 [DIRS 114134] in Table 4-1).

- Air-injection and/or gas tracer data from the Upper Tiva Canyon, Bow Ridge fault, and Upper Paintbrush contact alcoves, the Single Heater Test (SHT) area, and the Drift Scale Test (DST) area used for fracture permeability and porosity estimates (DTNs: LB980912332245.002 [DIRS 105593] and GS990883122410.002 [DIRS 135230]).

- Measured properties (including effective porosity, bulk density, porosity, particle density, hydraulic conductivity, matrix van Genuchten $\alpha$ and $m$ values, and residual saturation) and field variables (including volumetric water content, saturation, and water potential) from core samples, as well as stratigraphic descriptions for samples from boreholes used for developing matrix properties for UZ model layers (DTNs: MO0109HYMXPROP.001 [DIRS 155989] through GS940208314211.008 [DIRS 145581] in Table 4-1).

Specific input data sets and the associated Data Tracking Numbers (DTNs) are provided in Table 4-1. Equations that are "direct input" are discussed in the context of model development in Section 6 with appropriate citations to their sources. 
Table 4-1. Data Tracking Numbers for Input Data Used

\begin{tabular}{|c|c|c|}
\hline Data Description & DTN & Data Use ${ }^{a}$ \\
\hline $\begin{array}{l}\text { Matrix saturation, water potential, and } \\
\text { hydrologic property data }\end{array}$ & MO0109HYMXPROP.001 [DIRS 155989] & $\begin{array}{l}\text { 6.1.3.3 } \\
\text { App. A }\end{array}$ \\
\hline $\begin{array}{l}\text { Physical properties and water potential } \\
\text { for borehole samples from USW WT-24 }\end{array}$ & GS980708312242.010 [DIRS 106752] & App. A \\
\hline $\begin{array}{l}\text { Physical properties and water potential } \\
\text { for borehole samples from USW SD-6 }\end{array}$ & GS980808312242.014 [DIRS 106748] & App. A \\
\hline $\begin{array}{l}\text { Physical properties and hydraulic- } \\
\text { conductivity measurements from USW } \\
\text { WT-24 }\end{array}$ & GS980708312242.011 [DIRS 107150] & App. A \\
\hline $\begin{array}{l}\text { Physical properties and saturated- } \\
\text { hydraulic-conductivity measurements } \\
\text { from USW SD-6 }\end{array}$ & GS980908312242.038 [DIRS 107154] & App. A \\
\hline $\begin{array}{l}\text { Physical properties and saturated- } \\
\text { hydraulic-conductivity measurements } \\
\text { from boreholes USW SD-7, USW SD-9, } \\
\text { USW SD-12, USW UZ-14 and UE-25 } \\
\text { UZ\#16 }\end{array}$ & GS980908312242.041 [DIRS 107158] & App. A \\
\hline $\begin{array}{l}\text { Measured physical and hydraulic } \\
\text { properties of core samples from Busted } \\
\text { Butte boreholes }\end{array}$ & $\begin{array}{l}\text { GS990308312242.007 [DIRS 107185] } \\
\text { GS990708312242.008 [DIRS 109822] }\end{array}$ & App. A \\
\hline $\begin{array}{l}\text { Physical properties and saturated } \\
\text { hydraulic conductivity of cores from } \\
\text { surface samples from the ESF main drift } \\
29+00 \mathrm{~m} \text { to } 57+00 \mathrm{~m}\end{array}$ & GS971008312231.006 [DIRS 107184] & App. A \\
\hline $\begin{array}{l}\text { Water-retention data of borehole samples } \\
\text { and surface samples from ESF north } \\
\text { ramp }\end{array}$ & GS980908312242.037 [DIRS 107180] & App. A \\
\hline $\begin{array}{l}\text { Unsaturated hydraulic properties of } \\
\text { borehole samples from the PTn exposure } \\
\text { in the ESF north ramp }\end{array}$ & GS980408312242.008 [DIRS 107161] & App. A \\
\hline $\begin{array}{l}\text { Physical properties and saturated } \\
\text { hydraulic conductivity measurements of } \\
\text { core samples from boreholes in the ESF } \\
\text { north ramp }\end{array}$ & GS980908312242.040 [DIRS 107169] & App. A \\
\hline $\begin{array}{l}\text { Physical properties of borehole samples } \\
\text { from the PTn exposure in the ESF north } \\
\text { ramp }\end{array}$ & GS980308312242.005 [DIRS 107165] & App. A \\
\hline $\begin{array}{l}\text { Unsaturated water-retention data for } \\
\text { samples from USW SD-6 }\end{array}$ & GS980908312242.039 [DIRS 145272] & App. A \\
\hline $\begin{array}{l}\text { Moisture-retention data for samples from } \\
\text { boreholes USW SD-7, USW SD-9, USW } \\
\text { SD-12 and UE-25 UZ\#16 }\end{array}$ & GS960808312231.003 [DIRS 147590] & App. A \\
\hline $\begin{array}{l}\text { Unsaturated hydraulic properties from } \\
\text { USW WT-24 }\end{array}$ & GS980808312242.012 [DIRS 149375] & App. A \\
\hline $\begin{array}{l}\text { Moisture-retention data from boreholes } \\
\text { USW UZ-N27 and UE-25 UZ\#16. }\end{array}$ & GS950608312231.008 [DIRS 144662] & App. A \\
\hline $\begin{array}{l}\text { Unsaturated hydraulic conductivity and } \\
\text { water potential in Busted Butte volcanic } \\
\text { tuff cores }\end{array}$ & GS010608312242.001 [DIRS 160822] & App. A \\
\hline $\begin{array}{l}\text { Lithostratigraphic classification of core } \\
\text { samples for the Busted Butte Phase } 2 \\
\text { test block }\end{array}$ & LA0207SL831372.001 [DIRS 160824] & App. A \\
\hline
\end{tabular}


Table 4-1. Data Tracking Numbers for Input Data Used (Continued)

\begin{tabular}{|c|c|c|}
\hline Data Description & DTN & Data Use ${ }^{a}$ \\
\hline $\begin{array}{l}\text { Lithostratigraphic information and } \\
\text { chemical analyses from drill cores } \\
\text { collected in ESF }\end{array}$ & LAJF831222AQ98.014 [DIRS 160825] & App. A \\
\hline $\begin{array}{l}\text { Stratigraphic description and data for the } \\
\text { Yucca Mountain tuff in boreholes } \\
\text { NRG\#2B, NRG-7/7A, SD-9, UZ-14, } \\
\text { UZ\#16, UZ-N11, UZ-N33, UZ-N34, } \\
\text { UZ-N53, UZ-N54, UZ-N55 }\end{array}$ & GS950108314211.009 [DIRS 152556] & App. A \\
\hline $\begin{array}{l}\text { USW UZ-7a shift drilling summaries, } \\
\text { lithologic logs, structural logs, weight logs, } \\
\text { and composite borehole log from 0.0' to } \\
770.0^{\prime}\end{array}$ & TM000000UZ7ARS.001 [DIRS 160826] & App. A \\
\hline $\begin{array}{l}\text { Table of contacts in borehole USW } \\
\text { UZ-N35 }\end{array}$ & GS940208314211.007 [DIRS 155533] & App. A \\
\hline $\begin{array}{l}\text { Table of contacts for the Tiva Canyon tuff } \\
\text { in borehole USW UZ-N36 }\end{array}$ & GS940308314211.018 [DIRS 145589] & App. A \\
\hline $\begin{array}{l}\text { Lithostratigraphic data for Paintbrush } \\
\text { Group bedded tuff units in boreholes } \\
\text { USW UZ-N11, USW UZ-14, USW NRG- } \\
\text { 7/7A, USW SD-9, USW UZ-N37, USW } \\
\text { NRG-6, UE-25 NRG\#2B, USW UZ-N31, } \\
\text { USW UZ-N32, USW SD-12, UE-25 } \\
\text { UZ\#16, USW UZ-N54, USW UZ-N53 }\end{array}$ & GS950108314211.008 [DIRS 152558] & App. A \\
\hline $\begin{array}{l}\text { Stratigraphic descriptions of the Pah } \\
\text { Canyon tuff in boreholes UE-25 NRG\#2B, } \\
\text { UE-25 NRG\#4, USW NRG-6, } \\
\text { USW NRG-7/7A, USW SD-9, USW SD- } \\
\text { 12, USW UZ-14, USW UZ-N31, USW } \\
\text { UZ-N32, and USW UZ-N37 }\end{array}$ & GS950708314211.028 [DIRS 160827] & App. A \\
\hline $\begin{array}{l}\text { Tables of contacts in boreholes USW } \\
\text { UZ-N57, UZ-N58, UZ-N59, and UZ-N61 }\end{array}$ & GS940208314211.008 [DIRS 145581] & App. A \\
\hline $\begin{array}{l}\text { Developed fracture hydrologic properties } \\
\text { for UZ model layers (FY99) }\end{array}$ & LB990501233129.001 [DIRS 106787] & \begin{tabular}{|l|}
6.1 .2 \\
6.1 .3 .1 \\
6.1 .3 .3 \\
\end{tabular} \\
\hline $\begin{array}{l}\text { Air permeability data from vertical } \\
\text { boreholes }\end{array}$ & GS960908312232.013 [DIRS 105574] & $\begin{array}{l}\text { Section } 6.1 .1 \\
\text { Figure 6-2 } \\
\text { Table 6-4 } \\
\text { App. A }\end{array}$ \\
\hline Air permeability data from Alcoves $1,2,3$ & GS970183122410.001 [DIRS 105580] & $\begin{array}{l}\text { Table 6-4 } \\
\text { App. A }\end{array}$ \\
\hline $\begin{array}{l}\text { Air-injection and permeability data-SHT } \\
\text { area }\end{array}$ & LB960500834244.001 [DIRS 105587] & $\begin{array}{l}\text { Figure 6-2 } \\
\text { Table 6-4 } \\
\text { App. A }\end{array}$ \\
\hline $\begin{array}{l}\text { Air-injection and permeability data-DST } \\
\text { area }\end{array}$ & $\begin{array}{l}\text { LB970600123142.001 [DIRS 105589] } \\
\text { LB980120123142.004 [DIRS 105590] } \\
\text { LB980120123142.005 [DIRS 114134] } \\
\end{array}$ & $\begin{array}{l}\text { Figure 6-2 } \\
\text { Table 6-4 } \\
\text { App. A }\end{array}$ \\
\hline $\begin{array}{l}\text { Air-injection, tracer test, and fracture } \\
\text { porosity data }\end{array}$ & LB980912332245.002 [DIRS 105593] & \begin{tabular}{|l|}
6.1 .3 .1 \\
6.1 .3 .2 \\
6.1 .3 .3 \\
\end{tabular} \\
\hline $\begin{array}{l}\text { Detailed Line Survey and Full-Periphery } \\
\text { Geotechnical Map, and Comparative } \\
\text { Geological Cross Section }\end{array}$ & GS960908314224.020 [DIRS 106059] & App. A \\
\hline
\end{tabular}


Table 4-1. Data Tracking Numbers for Input Data Used (Continued)

\begin{tabular}{|c|c|c|}
\hline Data Description & DTN & Data Use ${ }^{a}$ \\
\hline Ghost Dance fault permeability & GS990883122410.002 [DIRS 135230] & 6.3 \\
\hline Geologic Framework Model (GFM2000) & MO0012MWDGFM02.002 [DIRS 153777] & $\begin{array}{l}6.3 \\
\text { App. A }\end{array}$ \\
\hline
\end{tabular}

a Sections where the data used are described in detail.

DST=Drift Scale Test; ESF = Exploratory Studies Facility; FY=Fiscal Year;

$\mathrm{PTn}=$ Upper Paintbrush non-welded vitric; SHT=Single Heater Test

\subsection{CRITERIA}

The general requirements to be satisfied by Total System Performance Assessment (TSPA) are stated in 10 CFR 63.114 [DIRS 156605] (Requirements for Performance Assessment). Technical requirements to be satisfied by TSPA are identified in the Yucca Mountain Project Requirements Document (Canori and Leitner 2003 [DIRS 166275]). The acceptance criteria that will be used by the Nuclear Regulatory Commission (NRC) to determine whether the technical requirements have been met are identified in Yucca Mountain Review Plan, Final Report (YMRP) (NRC 2003 [DIRS 163274]). The pertinent criteria and subcriteria for this analysis report are, from Criteria 1 through 3, contained in Section 2.2.1.3.6.3 Acceptance Criteria (for Section 2.2.1.3.6, Flow Paths in the Unsaturated Zone), which are based on meeting the requirements of 10 CFR 63.114 (a)-(c) and (e)-(g) [DIRS 156605], relating to flow paths in the unsaturated zone model abstraction (Table 4-2).

Table 4-2. Acceptance Criteria Applicable to This Analysis Report

\begin{tabular}{|c|l|l|l|}
\hline $\begin{array}{c}\text { Requirement } \\
\text { Number }^{\mathbf{a}}\end{array}$ & \multicolumn{1}{|c|}{ Requirement Title $^{\mathbf{a}}$} & \multicolumn{1}{c|}{ 10 CFR 63 Link } & \multicolumn{1}{c|}{$\begin{array}{c}\text { YMRP Acceptance } \\
\text { Criteria }^{\mathbf{b}}\end{array}$} \\
\hline PRD -002/T-015 & $\begin{array}{l}\text { Requirements for } \\
\text { Performance Assessment }\end{array}$ & $\begin{array}{l}\text { 10 CFR 63.114 (a)-(c) and } \\
(\mathrm{e}) \text {-(g) }\end{array}$ & 2.2.1.3.6.3, Criteria 1 to 3 \\
\hline
\end{tabular}

a from Canori and Leitner (2003 [DIRS 166275])

${ }^{\mathrm{b}}$ from NRC (2003 [DIRS 163274])

YMRP=Yucca Mountain Review Plan

The pertinent acceptance criteria from Section 2.2.1.3.6.3 of the YMRP (NRC 2003 [DIRS 163274]) are included below. In cases where subsidiary criteria are listed in the YMRP for a given criterion, only the subsidiary criteria addressed by this scientific analysis are listed below. Where a subcriterion includes several components, only some of those components may be addressed. How these components are addressed is summarized in Section 7.2 of this report.

\section{Acceptance Criteria from Section 2.2.1.3.6.3, Flow Paths in the Unsaturated Zone}

\section{Acceptance Criterion 1: System Description and Model Integration Are Adequate.}

(1) The total system performance assessment adequately incorporates, or bounds, important design features, physical phenomena, and couplings, and uses consistent and appropriate assumptions throughout the flow paths in the unsaturated zone abstraction process. Couplings include thermal-hydrologic-mechanical-chemical effects, as appropriate; 
(2) The aspects of geology, hydrology, geochemistry, physical phenomena, and couplings that may affect flow paths in the unsaturated zone are adequately considered. Conditions and assumptions in the abstraction of flow paths in the unsaturated zone are readily identified and consistent with the body of data presented in the description;

(3) The abstraction of flow paths in the unsaturated zone uses assumptions, technical bases, data, and models that are appropriate and consistent with other related U.S. Department of Energy abstractions. For example, the assumptions used for flow paths in the unsaturated zone are consistent with the abstractions of quantity and chemistry of water contacting waste packages and waste forms, climate and infiltration, and flow paths in the saturated zone (Sections 2.2.1.3.3, 2.2.1.3.5, and 2.2.1.3.8 of the Yucca Mountain Review Plan [DIRS 163274], respectively). The descriptions and technical bases are transparent and traceable to site and design data;

(7) Average parameter estimates used in process-level models are representative of the temporal and spatial discretizations considered in the model;

(9) Guidance in NUREG-1297 (Altman et al. 1988 [DIRS 103597]) and NUREG-1298 (Altman et al. 1988 [DIRS 103750]), or other acceptable approaches for peer review and data qualification is followed.

\section{Acceptance Criterion 2: Data Are Sufficient for Model Justification.}

(1) Hydrological and thermal-hydrological-mechanical-chemical values used in the license application are adequately justified. Adequate descriptions of how the data were used, interpreted, and appropriately synthesized into the parameters are provided;

(2) The data on the geology, hydrology, and geochemistry of the unsaturated zone, are collected using acceptable techniques;

\section{Acceptance Criterion 3: Data Uncertainty is Characterized and Propagated Through the Model Abstraction.}

(6) Uncertainties in the characteristics of the natural system and engineered materials are considered.

\subsection{CODES, STANDARDS, AND REGULATIONS}

No codes, standards, or regulations other than those identified in the Project Requirements Document (Canori and Leitner 2003 [DIRS 166275], Table 2-3) and determined to be applicable in Table 4-2, were used in this report. 


\section{ASSUMPTIONS}

The assumptions made to determine hydrologic properties, in the absence of direct confirmation data or evidence, are as follows:

1. No air-injection data are available for calculating the fracture permeability values for the Prow Pass (pp), Bullfrog (bf), and Tram (tr) units. Therefore, analogues, based on the similarity of matrix properties, the degree of zeolitic alteration, and degree of welding, are assumed to be appropriate for calculating the fracture permeability values for those units. This can be justified based on the following two considerations. First, this report only provides the initial guesses of the fracture permeability for the calibrated properties model, and the UZ flow simulations use the calibrated permeability values from the calibrated properties model. Therefore, using assumptions in calculating the initial guesses of the permeability shall not significantly affect the final UZ flow simulations that feed results to TSPA. Second, the geological similarity is a reasonable basis for the analogue approach described above.

2. An upper limit of 1.5 orders-of-magnitude upscaling is assumed to be appropriate for calculating upscaled matrix permeability. This is based mainly on the following considerations. First, the upscaling law (Equation 6-28) was developed for a porous medium (single continuum) and can only be considered as an approximation for a dual-continuum system. For example, the existence of fractures, which may act as a capillary barrier, can increase tortuosity of liquid water flow in the matrix and therefore reduce the effective permeability compared to the case without fractures. Second, this report only provides the initial guesses of the matrix permeability for the calibrated properties model and the UZ flow simulations use the calibrated permeability values from the calibrated properties model. Therefore, using assumptions in calculating the initial guesses of the permeability shall not significantly affect the final UZ flow simulations that feed results to TSPA. Third, the use of the upper limit for upscaling is practically necessary given the uncertainty resulting from both the approximation nature of the upscaling law (developed for porous media) and the sparseness of data available for calculating the permeability variance that is used for determining the upscaled permeability.

Other scientific analysis assumptions are described in Section 6 of this analysis report where they are used. 


\section{INTENTIONALLY LEFT BLANK}




\section{SCIENTIFIC ANALYSIS DISCUSSION}

In this section, the methodologies and data used to determine representative estimates of the fracture and matrix properties for the UZ Model layers are discussed. Table 6-1 shows the relationships between the lithostratigraphy of the Geologic Framework Model (GFM2000) (BSC 2004 [DIRS 170029]) and the UZ Model layers, as documented in a scientific analysis report describing development of numerical grids for UZ flow and transport modeling (BSC 2004 [DIRS 169855], Table 6-5). Note that the relationship between major units and hydrogeologic units in Table 6-1 is slightly different from Table 1 of Characterization of Hydrogeologic Units Using Matrix Properties, Yucca Mountain, Nevada (Flint 1998 [DIRS 100033]). A detailed discussion of these differences is documented in Sections 6.3 and 6.4 as well as Table 6-5 of Development of Numerical Grids for UZ Flow and Transport Modeling (BSC 2004 [DIRS 169855]). Most fracture and matrix properties or parameters estimated in this report are used as inputs in the inversion modeling studies documented in the model report Calibrated Properties Model (BSC 2004 [DIRS 169857]). The key scientific notebooks (with relevant page numbers) used for this study are listed in Table 6-2. Two assumptions are used in this section, as presented in Section 5. The intended use of the output data, developed using approaches documented in this section, is given in Section 1.

In this report, the heterogeneity of the Yucca Mountain UZ is modeled by a number of layers, each of which has homogeneous and isotropic hydrologic properties, based on the following considerations: First, the overall behavior of flow and transport processes in the Yucca Mountain UZ is mainly determined by relatively large-scale heterogeneities introduced by stratification of the tuffs (Zhou et al. 2003 [DIRS 162133]). Second, the complexity of models for heterogeneity and anisotropicity needs to be consistent with the available data while the available data are too sparse to characterize the detailed heterogeneity and anisotropicity within each UZ model layer. Third, this layered approach is supported by field observations, such as matrix water saturation distributions. For a given geologic unit, measured matrix saturation distributions can be very similar in different boreholes (Flint 1998 [DIRS 100033], pp. 24 to 30, Figures 5 to 9), indicating that matrix flow behavior and effective hydraulic properties should be

similar within the unit. Further discussion of this issue is provided in a model report, Conceptual Model and Numerical Approaches for Unsaturated Zone Flow and Transport (BSC 2004 [DIRS 170035], Section 6.3.4). 
Table 6-1. Correlation of GFM2000 Lithostratigraphy, UZ Model Layer, and Hydrogeologic Unit

\begin{tabular}{|c|c|c|c|}
\hline $\begin{array}{c}\text { Major Unit } \\
\text { (Modified from } \\
\text { Montazer and Wilson } \\
\text { 1984 [DIRS 100161]) }\end{array}$ & $\begin{array}{c}\text { GFM2000 } \\
\text { Lithostratigraphic } \\
\text { Nomenclature }\end{array}$ & $\begin{array}{c}\text { UZ Model Layer } \\
\text { (BSC 2004 } \\
\text { [DIRS 169855], } \\
\text { Table 6-5) } \\
\end{array}$ & $\begin{array}{c}\text { Hydrogeologic Unit } \\
\text { (Flint 1998 } \\
\text { [DIRS 100033], Table 1) }\end{array}$ \\
\hline \multirow{5}{*}{$\begin{array}{l}\text { Tiva Canyon Welded } \\
\text { (TCW) }\end{array}$} & Tpcr & tcw11 & CCR, CUC \\
\hline & Tрср & \multirow[t]{2}{*}{ tcw12 } & \multirow[t]{2}{*}{ CUL, CW } \\
\hline & TpcLD & & \\
\hline & Tpcpv3 & \multirow[t]{2}{*}{ tcw13 } & \multirow[t]{2}{*}{ CMW } \\
\hline & Tpcpv2 & & \\
\hline \multirow{10}{*}{$\begin{array}{l}\text { Paintbrush nonwelded } \\
\text { (PTn) }\end{array}$} & Tpcpv1 & ptn21 & CNW \\
\hline & Tpbt4 & \multirow[t]{2}{*}{ ptn22 } & \multirow[t]{2}{*}{ BT4 } \\
\hline & \multirow[t]{3}{*}{ Tpy (Yucca) } & & \\
\hline & & ptn23 & TPY \\
\hline & & \multirow[t]{2}{*}{ ptn24 } & \multirow[t]{2}{*}{ BT3 } \\
\hline & Tpbt3 & & \\
\hline & Tpp (Pah) & ptn25 & TPP \\
\hline & Tpbt2 & \multirow[t]{3}{*}{ ptn26 } & \multirow[t]{3}{*}{ BT2 } \\
\hline & Tptrv3 & & \\
\hline & Tptrv2 & & \\
\hline \multirow{11}{*}{$\begin{array}{l}\text { Topopah Spring welded } \\
\text { (TSw) }\end{array}$} & Tptrv1 & \multirow[t]{2}{*}{ tsw31 } & \multirow[t]{2}{*}{ TC } \\
\hline & \multirow[t]{2}{*}{ Tptrn } & & \\
\hline & & tsw32 & TR \\
\hline & Tptrl, Tptf & \multirow[t]{2}{*}{ tsw33 } & \multirow[t]{2}{*}{ TUL } \\
\hline & Tptpul, RHHtop & & \\
\hline & Tptpmn & tsw34 & TMN \\
\hline & Tptpll & tsw35 & TLL \\
\hline & \multirow[t]{2}{*}{ Tptpln } & tsw36 & $\begin{array}{l}\text { TM2 (upper 2/3 of } \\
\text { Tptpln) }\end{array}$ \\
\hline & & tsw37 & $\begin{array}{l}\text { TM1 (lower } 1 / 3 \text { of } \\
\text { Tptpln) }\end{array}$ \\
\hline & Tptpv3 & tsw38 & PV3 \\
\hline & Tptpv2 & tsw39 (vit, zeo) & PV2 \\
\hline
\end{tabular}


Table 6-1. Correlation of GFM2000 Lithostratigraphy, UZ Model Layer, and Hydrogeologic Unit (Continued)

\begin{tabular}{|c|c|c|c|}
\hline $\begin{array}{c}\text { Major Unit } \\
\text { (Modified from } \\
\text { Montazer and Wilson } \\
1984 \text { [DIRS 100161]) }\end{array}$ & $\begin{array}{l}\text { GFM2000 } \\
\text { Lithostratigraphic } \\
\text { Nomenclature }\end{array}$ & $\begin{array}{l}\text { UZ Model Layer } \\
\text { (BSC 2004 } \\
\text { [DIRS 169855], } \\
\text { Table 6-5) } \\
\end{array}$ & $\begin{array}{c}\text { Hydrogeologic Unit } \\
\text { (Flint 1998 } \\
\text { [DIRS 100033], Table 1) }\end{array}$ \\
\hline \multirow{14}{*}{$\begin{array}{l}\text { Calico Hills nonwelded } \\
(\mathrm{CHn})\end{array}$} & Tptpv1 & \multirow[t]{2}{*}{ ch1 (vit, zeo) } & \multirow[t]{2}{*}{ BT1 or BT1a (altered) } \\
\hline & Tpbt1 & & \\
\hline & \multirow[t]{4}{*}{ Tac (Calico) } & ch2 (vit, zeo) & \multirow{4}{*}{$\begin{array}{l}\mathrm{CHV} \text { (vitric) or } \mathrm{CHZ} \\
\text { (zeolitic) }\end{array}$} \\
\hline & & ch3 (vit, zeo) & \\
\hline & & ch4 (vit, zeo0 & \\
\hline & & ch5 (vit, zeo) & \\
\hline & Tacbt (Calicobt) & ch6 (vit, zeo) & BT \\
\hline & Tcpuv (Prowuv) & $\mathrm{pp} 4$ & PP4 (zeolitic) \\
\hline & Tcpuc (Prowuc) & pp3 & PP3 (devitrified) \\
\hline & Tcpmd (Prowmd) & \multirow[t]{2}{*}{ pp2 } & \multirow[t]{2}{*}{ PP2 (devitrified) } \\
\hline & Tcplc (Prowlc) & & \\
\hline & Tcplv (Prowlv) & \multirow[t]{3}{*}{ pp1 } & \multirow[t]{3}{*}{ PP1 (zeolitic) } \\
\hline & Tcpbt (Prowbt) & & \\
\hline & Tcbuv (Bullfroguv) & & \\
\hline \multirow{11}{*}{$\begin{array}{l}\text { Crater Flat } \\
\text { undifferentiated (CFu) }\end{array}$} & Tcbuc (Bullfroguc) & \multirow[t]{3}{*}{ bf3 } & \multirow[t]{3}{*}{ BF3 (welded) } \\
\hline & Tcbmd (Bullfrogmd) & & \\
\hline & Tcblc (Bullfroglc) & & \\
\hline & Tcblv (Bullfroglv) & \multirow[t]{3}{*}{ bf2 } & \multirow[t]{3}{*}{ BF2 (nonwelded) } \\
\hline & Tcbbt (Bullfrogbt) & & \\
\hline & Tctuv (Tramuv) & & \\
\hline & Tctuc (Tramuc) & \multirow[t]{3}{*}{ tr3 } & \multirow[t]{3}{*}{ Not Available } \\
\hline & Tctmd (Trammd) & & \\
\hline & Tctlc (Tramlc) & & \\
\hline & Tctlv (Tramlv) & \multirow[t]{2}{*}{ tr2 } & \multirow[t]{2}{*}{ Not Available } \\
\hline & $\begin{array}{l}\text { Tctbt (Trambt) and } \\
\text { below }\end{array}$ & & \\
\hline
\end{tabular}

Source: BSC (2004 [DIRS 169855], Table 6-5)

Table 6-2. Scientific Notebooks

\begin{tabular}{|l|l|l|l|}
\hline $\begin{array}{c}\text { Lawrence Berkeley } \\
\text { National Laboratory } \\
\text { Scientific Notebook ID }\end{array}$ & $\begin{array}{c}\text { Management and } \\
\text { Operations Contractor } \\
\text { Scientific Notebook ID }\end{array}$ & \multicolumn{1}{|c|}{ Relevant Pages } & \multicolumn{1}{c|}{ Citation } \\
\hline YMP-LBNL-GSB-1.1.2 & SN-LBNL-SCI-003-V1 & $93-94,117-127,145-146$ & Ahlers 2000 [DIRS 155853] \\
\hline YMP-LBNL-GSB-LHH-3 & SN-LBNL-SCI-215-V1 & $35-53,101$ & Wang 2003 [DIRS 161654] \\
\hline YMP-LBNL-UZ-CFA-1 & SN-LBNL-SCI-003-V2 & $57-83$ & Wang 2003 [DIRS 161654] \\
\hline
\end{tabular}

The selected FEPs for this report (Table 6-3) are those taken from the license application (LA) FEP list (DTN: MO0407SEPFEPLA.000 [DIRS 170760]) and are associated with the subject matter of this report. Consideration of the license application FEP list is in accordance with the activities represented in the TWP (BSC 2004 [DIRS 169654], Table 2.1.5-1). The discussion in 
this and other model and analysis reports form the technical basis for evaluation of the listed FEPs. The cross reference for each FEP to the relevant section of this report is given below.

Table 6-3. FEPs Addressed in this Analysis Report

\begin{tabular}{|l|l|l|}
\hline \multicolumn{1}{|c|}{ FEP No. } & \multicolumn{1}{|c|}{ FEP Name } & \multicolumn{1}{c|}{ Relevant Section and Tables } \\
\hline $1.2 .02 .01 .0 \mathrm{~A}$ & Fractures & 6.1 \\
\hline $1.2 .02 .02 .0 \mathrm{~A}$ & Faults & 6.3 \\
\hline $2.2 .03 .01 .0 \mathrm{~A}$ & Stratigraphy & 6, Tables 6-1, 6-4, 6-5, and 6-6 \\
\hline $2.2 .03 .02 .0 \mathrm{~A}$ & Rock properties of host rock and other units & $6.1,6.2$, and 6.3 \\
\hline $2.2 .07 .02 .0 \mathrm{~A}$ & Unsaturated groundwater flow in geosphere & $6.1,6.2$, and 6.3 \\
\hline $2.2 .07 .08 .0 \mathrm{~A}$ & Fracture flow in the UZ & 6.1 \\
\hline
\end{tabular}

FEP=Feature, Event, and Process

The following subsections present the methods used to determine fracture properties, matrix properties, and fault properties.

\subsection{FRACTURE PROPERTIES}

Fracture properties determined in this report include fracture frequency, fracture aperture, fracture porosity, fracture interface area, uncalibrated van Genuchten fracture $\alpha$ and $m$, and uncalibrated fracture permeability. The development of fracture properties is documented in a Scientific Notebook (Wang 2003 [DIRS 161654], SN-LBNL-SCI-215-V1, pp. 35 to 53). Excel files used for calculating fracture properties are listed and described in Appendix A. Excel files lecan97.xls, UTCA_BRFA.xls, drift.xls, and airk.xls are used for calculating fracture permeability values, and Fpor.x $\bar{l} s$ is used for determining fracture porosity values.

\subsubsection{Fracture Permeability}

The fracture permeabilities calculated here for the UZ Model layers are based on air permeabilities inferred from air-injection tests performed in vertical boreholes and in ESF alcoves. Permeabilities inferred from air-injection tests in boreholes are representative of fracture absolute permeabilities because the fractures were dry during the tests. These permeabilities were determined based on pneumatic-pressure data and are calculated using a modified version of Hvorslev's (Hvorslev 1951 [DIRS 101868], p. 30, Case 8) solution for steady-state ellipsoidal flow (LeCain 1995 [DIRS 101700], p. 10). The determined permeability values are combined here to determine effective fracture permeabilities for the UZ Model layers. The geometric averaging is one of the most widely used simple upscaling methods (Wen and Gomez-Hernandez 1996 [DIRS 170239], p. xii to xiii). Therefore, geometric means of these fracture permeabilities are considered to reflect upscaling of these permeabilities for use as single values representative for each model layer, and can be a good starting point for calibration. There is a theoretical basis for the independence of permeability from particular test fluids, as long as the test medium can be viewed as a rigid continuum. Thus, fracture permeabilities derived from air-injection tests are considered to be applicable to liquid water flow in fractures.

The data sources available for calculating the fracture permeability values are different for different hydrogeologic units as listed in Table (6-4). For the Tiva Canyon welded hydrogeologic unit $(\mathrm{TCw})$, fracture permeabilities were based on air-injection tests performed in 
boreholes NRG-7a, NRG-6, SD-12, and UZ\#16, as well as in the Upper Tiva Canyon, Bow Ridge fault, and Upper Paintbrush contact alcoves (Alcoves 1, 2 and 3, respectively). For the Paintbrush nonwelded hydrogeologic unit (PTn), the permeability data are from borehole NRG-7a and the Upper Paintbrush contact alcove (Alcove 3). For the Topopah Spring welded hydrogeologic unit (TSw), the permeability data are from boreholes NRG-7a, NRG-6, SD-12, and UZ\#16, as well as from the Single Heater Test and Drift Scale Test areas in Alcove 5. For the Calico Hills nonwelded hydrogeologic unit $(\mathrm{CHn})$, permeability data are available only from a single sampled interval in the borehole UZ\#16. The locations of the boreholes are given in Figure 6-1. No air-injection data are available for the Prow Pass (pp), Bullfrog (bf), and Tram (tr) units. For model layers where no air injection data are available, analogs of other units are used, based on the similarity of the matrix properties, the degree of zeolitic alteration and degree of welding. These fracture permeabilities are used only as prior information and initial estimates for the Calibrated Properties Model (BSC 2004 [DIRS 169857]). 


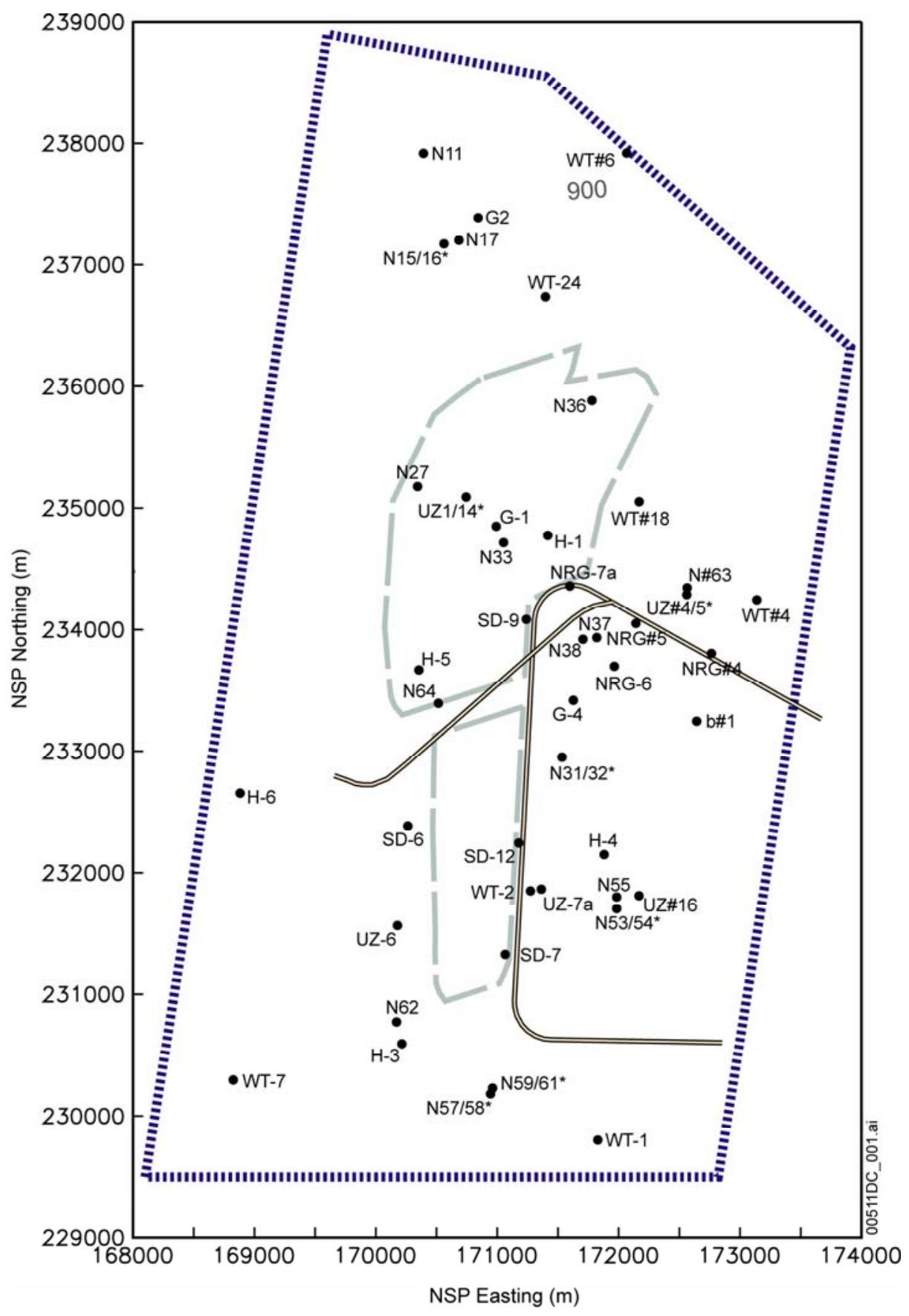

\begin{tabular}{|c|c|c|}
\hline \multicolumn{3}{|l|}{ LEGEND } \\
\hline 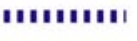 & UZ2002 Model Boundary & Borehole \\
\hline 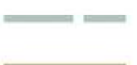 & 2002 Repository Boundary & $\begin{array}{c}\text { Note: * Denotes single location used for } \\
\text { adjacent boreholes. }\end{array}$ \\
\hline
\end{tabular}

Source: Adapted from BSC (2004 [DIRS 169857], Figure 4-1).

Figure 6-1. Schematic Showing Locations of Selected Boreholes 
Table 6-4 lists the geometric means of the fracture permeabilities for the UZ Model layers. The lithostratigraphic units were assigned to the UZ Model layers as listed in Table 6-1. The fracture permeabilities were treated as isotropic, and the data from vertical boreholes, and from the horizontal and inclined boreholes in the ESF alcoves were combined. The scales of these measurements are similar, as discussed later in Section 6.1.1.1.

Table 6-4. Uncalibrated Fracture Permeabilities for the UZ Model Layers

\begin{tabular}{|c|c|c|c|c|c|}
\hline \multirow[t]{2}{*}{$\begin{array}{c}\text { UZ } \\
\text { Model Layer } \\
\end{array}$} & \multicolumn{5}{|c|}{$\begin{array}{c}\text { Fracture } \\
\text { Permeability }\left(\mathrm{m}^{2}\right)\end{array}$} \\
\hline & Basis $^{a}$ & $k_{G}{ }^{b}$ & $\log \left(k_{G}\right)$ & $\sigma_{\log \left(k_{G}\right)^{c}}$ & $\mathrm{~N}^{\mathrm{d}}$ \\
\hline tcw11 & BRFA & $3.0 \mathrm{E}-11$ & -10.52 & 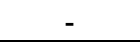 & 2 \\
\hline tcw12 & $\begin{array}{l}\text { UTCA } \\
\text { UPCA } \\
\text { NRG-6 } \\
\text { NRG-7a } \\
\text { SD-12 } \\
\text { UZ\#16 } \\
\end{array}$ & $5.3 \mathrm{E}-12$ & -11.28 & 0.78 & 80 \\
\hline tcw13 & $\begin{array}{l}\text { UPCA } \\
\text { NRG-7a }\end{array}$ & $4.5 \mathrm{E}-12$ & -11.35 & 1.15 & 3 \\
\hline ptn21 & $\begin{array}{l}\text { UPCA } \\
\text { NRG-7a }\end{array}$ & 3.2E-12 & -11.49 & 0.88 & 12 \\
\hline ptn22 & NRG-7a & 3.0E-13 & -12.52 & 0.20 & 4 \\
\hline ptn23 & NRG-7a & 3.0E-13 & -12.52 & 0.20 & 4 \\
\hline ptn24 & NRG-7a & 3.0E-12 & -11.52 & - & 1 \\
\hline ptn25 & NRG-7a & 1.7E-13 & -12.78 & 0.10 & 7 \\
\hline ptn26 & NRG-7a & 2.2E-13 & -12.66 & - & 1 \\
\hline tsw31 & Average TSW & $8.1 \mathrm{E}-13$ & -12.09 & - & - \\
\hline tsw32 & $\begin{array}{l}\text { NRG-6 } \\
\text { NRG-7a } \\
\text { SD-12 } \\
\text { UZ\#16 }\end{array}$ & 7.1E-13 & -12.15 & 0.66 & 31 \\
\hline tsw33 & $\begin{array}{l}\text { NRG-6 } \\
\text { NRG-7a } \\
\text { SD-12 } \\
\text { UZ\#16 }\end{array}$ & $7.8 \mathrm{E}-13$ & -12.11 & 0.61 & 27 \\
\hline tsw34 & $\begin{array}{l}\text { SHT } \\
\text { DST } \\
\text { NRG-6 } \\
\text { NRG-7a } \\
\text { SD-12 } \\
\text { UZ\#16 }\end{array}$ & 3.3E-13 & -12.48 & 0.47 & 180 \\
\hline alternate tsw34 & $\begin{array}{l}\text { SHT } \\
\text { DST } \\
\text { NRG-6 } \\
\text { NRG-7a } \\
\text { SD-12 } \\
\text { UZ\#16 }\end{array}$ & $1.5 \mathrm{E}-13$ & -12.81 & 0.75 & 180 \\
\hline tsw35 & $\begin{array}{l}\text { NRG-7a } \\
\text { UZ\#16 }\end{array}$ & $9.1 \mathrm{E}-13$ & -12.04 & 0.54 & 31 \\
\hline
\end{tabular}


Table 6-4. Uncalibrated Fracture Permeabilities for the UZ Model Layers (Continued)

\begin{tabular}{|c|c|c|c|c|c|}
\hline \multirow[t]{2}{*}{$\begin{array}{c}\text { UZ } \\
\text { Model Layer } \\
\end{array}$} & \multicolumn{5}{|c|}{$\begin{array}{c}\text { Fracture } \\
\text { Permeability }\left(\mathrm{m}^{2}\right)\end{array}$} \\
\hline & Basis $^{a}$ & $\mathbf{k}_{G}{ }^{b}$ & $\log \left(k_{G}\right)$ & $\sigma_{\log \left(k_{G}\right)^{c}}$ & $\mathrm{~N}^{\mathrm{d}}$ \\
\hline $\begin{array}{l}\text { tsw36 through } \\
\text { tsw37 }\end{array}$ & $\begin{array}{l}\text { SD-12 } \\
\text { UZ\#16 }\end{array}$ & 1.3E-12 & -11.87 & 0.28 & 19 \\
\hline tsw38 & $\begin{array}{l}\text { Average } \\
\text { TSw }\end{array}$ & $8.1 \mathrm{E}-13$ & -12.09 & - & - \\
\hline tsw39 & $\begin{array}{l}\text { Average } \\
\text { TSw }\end{array}$ & $8.1 \mathrm{E}-13$ & -12.09 & - & - \\
\hline ch1Ze & ch2Ze & $2.5 \mathrm{E}-14$ & $\begin{array}{l}-13.60 \\
\end{array}$ & - & - \\
\hline ch1VI & ptn26 & $2.2 \mathrm{E}-13$ & -12.66 & - & - \\
\hline $\begin{array}{l}\text { ch2VI through } \\
\text { ch5VI }\end{array}$ & ptn26 & $2.2 \mathrm{E}-13$ & -12.66 & - & - \\
\hline $\begin{array}{l}\text { ch2Ze through } \\
\text { ch5Ze }\end{array}$ & UZ\#16 & $2.5 \mathrm{E}-14$ & -13.60 & - & 1 \\
\hline ch6 & ch2Ze & $2.5 \mathrm{E}-14$ & -13.60 & - & - \\
\hline $\mathrm{pp} 4$ & ch2Ze & $2.5 \mathrm{E}-14$ & -13.60 & - & - \\
\hline pp3 & ptn26 & $2.2 \mathrm{E}-13$ & -12.66 & - & - \\
\hline pp2 & ptn26 & $2.2 \mathrm{E}-13$ & -12.66 & - & - \\
\hline pp1 & ch2Ze & $2.5 \mathrm{E}-14$ & -13.60 & - & - \\
\hline bf3 & ptn26 & $2.2 \mathrm{E}-13$ & -12.66 & - & - \\
\hline bf2 & ch2Ze & $2.5 \mathrm{E}-14$ & -13.60 & - & - \\
\hline tr3 & ptn26 & $2.2 \mathrm{E}-13$ & -12.66 & - & - \\
\hline tr2 & ch2Ze & $2.5 \mathrm{E}-14$ & -13.60 & - & - \\
\hline
\end{tabular}

Output DTN: LB0205REVUZPRP.001.

Source: DTNs: GS960908312232.013 [DIRS 105574]; GS970183122410.001

[DIRS 105580]; LB970600123142.001 [DIRS 105589];

LB980120123142.004 [DIRS 105590]; LB980120123142.005

[DIRS 114134]; LB960500834244.001 [DIRS 105587].

${ }^{a}$ Identifies the corresponding air-injection borehole(s) and/or alcove(s) or analog to another model layer(s). UTCA-Upper Tiva Canyon Alcove, BRFA-Bow Ridge fault Alcove, UPCAUpper Paintbrush Contact Alcove, and NRG-6, NRG-7a, SD-12, and UZ\#16 are vertical boreholes. (This column is presented for information only and is not from the cited DTN.)

${ }^{b}$ Geometric mean

c Standard deviation

${ }^{d}$ Number of sampled intervals

"-" indicates that no data are available

DST=Drift Scale Test; SHT=Single Heater Test

The mean fracture permeabilities range from $2.5 \times 10^{-14} \mathrm{~m}^{2}$ to $3.0 \times 10^{-11} \mathrm{~m}^{2}$. The Tiva Canyon welded unit $(\mathrm{TCw})$ has the highest fracture permeabilities. Topopah Spring welded unit (TSw) fracture permeabilities are, in general, higher than those for the nonwelded Paintbrush (PTn) and Calico Hills $(\mathrm{CHn})$ units. Two fracture permeabilities are shown for the Topopah Spring middle nonlithophysal unit (tsw34). These represent two different approaches for weighting the available air-injection data. For tsw34, there were 143 sampled intervals in the Alcove 5 heater test areas compared to 37 sampled intervals in the four vertical borehole injection tests. For the first case, the data from Alcove 5 were weighted with those from the vertical borehole tests $\left(\mathrm{k}=0.8 \mathrm{k}_{\mathrm{G} \text {,vertical boreholes }}+0.2 \mathrm{k}_{\mathrm{G} \text {,Alcove } 5}\right)$, considering that the boreholes are distributed over a much larger area (i.e., sparser sampling) than that the Alcove covers (i.e., denser sampling). In the alternate tsw34 case, each sampled interval was weighted equally. 
The uncertainty and variability of fracture permeabilities for the UZ Model layers are reflected by the standard deviations reported in Table 6-4. These standard deviations result in 95 percent confidence intervals covering three orders of magnitude, even for the units that have a large number of sampled intervals. The data indicate that fracture permeabilities are highly variable.

\subsubsection{Scaling Issues}

Scaling issue arises when the fracture permeability is measured at a scale different from the one used in numerical simulations. Wen and Gomez-Hernandez (1996 [DIRS 170239]) reviewed the techniques for upscaling of block hydraulic conductivities range from the simple averaging of the heterogenous values within the block to sophisticated inversions, after obtaining the solution of the flow equation at the measurement scale. Renard and de Marsily (1997 [DIRS 170240]) provided another review on the scaling issue but focused on the equivalent permeability for uniform, single-phase, steady-state flow. For most numerical simulations of real world problems such as the UZ, the permeability (or conductivity) is actually defined on the scale of grid blocks. That the block permeability (or block conductivity) is not an instrinsic characteristic of the medium but subject to the flow conditions is well known (Renard and de Marsily 1997 [DIRS 170240], p. 255; Wen and Gomez-Hernandez 1996 [DIRS 170239], p. xxvii). For the fractured porous rock (i.e., the tuffs in Yucca Mountain), the situations are more complicated than heterogeneous porous media. Therefore, when using the permeability values, especially fracture permeability values, developed in this report, special attention is needed at the scale at which the permeability values have been measured and averaged. In most cases, a proper inversion modeling or manual calibration is recommended to obviate the problems of scale change (Renard and de Marsily 1997 [DIRS 170240], p. 253). The following paragraph is a summary of measuring scales and averaging method used in developing the fracture permeability values for each UZ Model layer.

The permeabilities measured in the vertical boreholes and alcoves were combined to determine the fracture permeability for each UZ Model layer. The straddle packer test interval lengths were approximately $4 \mathrm{~m}$ for vertical boreholes, 1 to $3 \mathrm{~m}$ for Alcoves 1,2 , and 3, and 5 to $12 \mathrm{~m}$ in the Single Heater Test (SHT) and DST areas (Alcove 5). These data were considered to be on the same relative scale and representative of the fracture permeability on the scale of the UZ Model, using geometric means. Additional air-permeability data on a scale of one-foot intervals are also available from air-injection testing in niches in the ESF in the Topopah Spring middle nonlithophysal unit (tsw34). The air-injection data from the niche studies are not used here for determining mean fracture permeabilities for the model layers, since these data are on a smaller scale and may not be representative of larger-scale effective permeability. Figure 6-2 compares the geometric means and range of data (mean \pm standard deviation) for the model layer tsw34 corresponding to Tptpmn (Table 6-1) (Wang 2003 [DIRS 161654], SN-LBNL-SCI-215-V1, p. 101). The data shown for the niche studies are inferred from pre-excavation air-injection testing. The ranges of the data overlap, but the geometric means for the measurements from the niche studies are generally lower than the other values. 


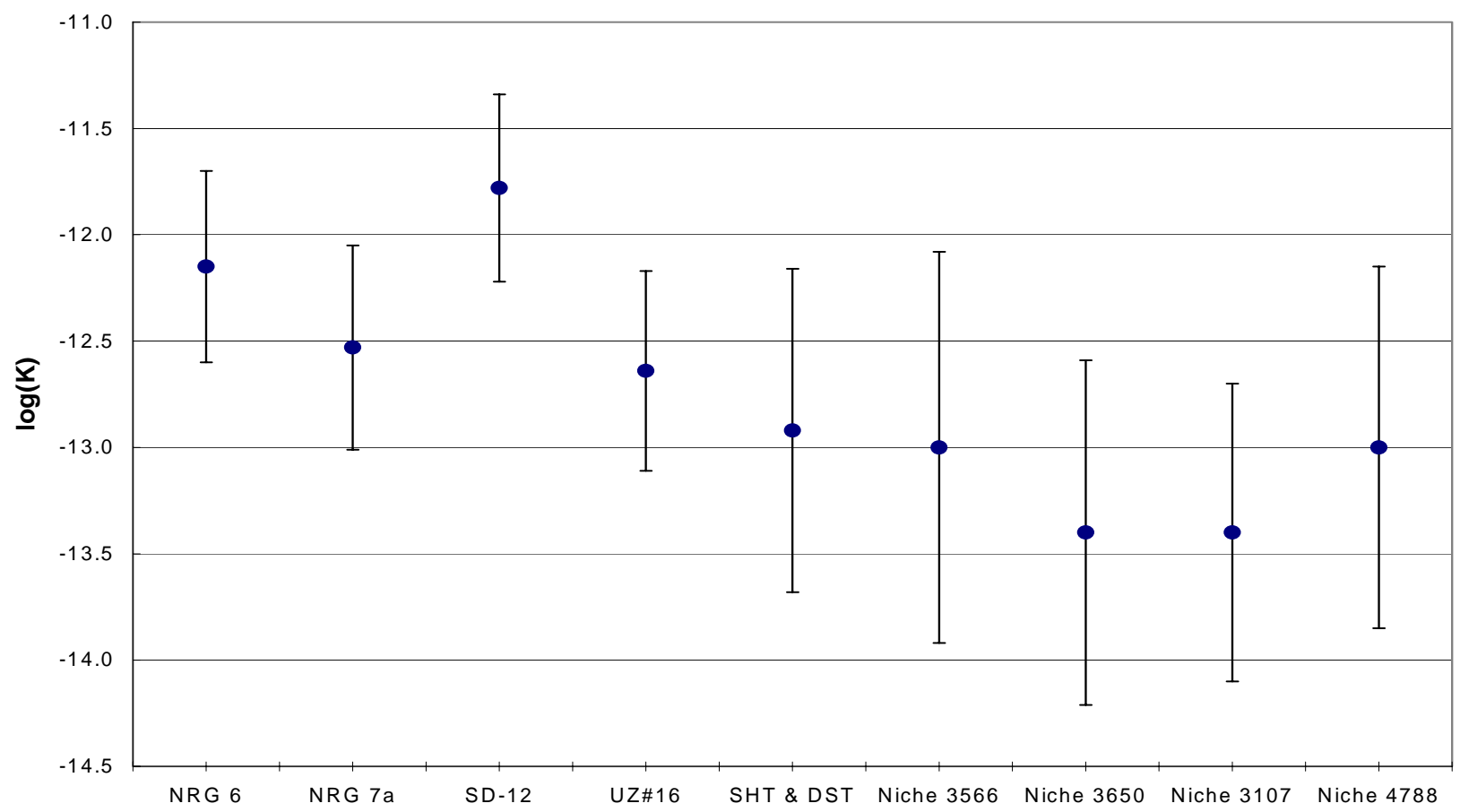

Source: DTNs: GS960908312232.013 [DIRS 105574], LB960500834244.001 [DIRS 105587], LB970600123142.001 [DIRS 105589], LB980120123142.004 [DIRS 105590], LB980120123142.005 [DIRS 114134], LB990901233124.004 [DIRS 123273] are shown by Wang (2003 [DIRS 161654], SN-LBNL-SCI-215-V1, p. 101) and in spreadsheet drift.xls, in Appendix A.

NOTE: Permeabilities were inferred from air-injection data. The filled circle indicates geometric mean, and range is \pm one standard deviation. For details of calculations, see Appendix A, p. A-24.

Figure 6-2. Fracture Permeabilities for Topopah Spring Middle Nonlithophysal Unit

\subsubsection{Fracture Frequency, Intensity, Interface Area, Aperture, and van Genuchten Parameters}

Fracture frequency, interface area, and the van Genuchten $m$ are obtained from qualified fracture property data (DTN: LB990501233129.001 [DIRS 106787]) developed from field data. These include detailed line survey (DLS) fracture data (collected from the ESF North and South Ramps, Main Drift, and ECRB Cross-Drift, providing spatially varying frequency, length, and fracture dips and strikes) and fracture frequency data from boreholes.

For completeness, mathematical equations used for developing these properties in DTN: LB990501233129.001 [DIRS 106787] are also described here.

The mean fracture frequency is calculated as the inverse of the mean spacing obtained from the DLS in the ESF and ECRB Cross-Drift. The mean spacing is calculated by:

$$
\bar{s}=\frac{1}{n f-1} \sum_{2}^{n f}\left(D_{i}-D_{i-1}\right)
$$


where $\left(D_{i}-D_{i-1}\right)$ is the spacing between two adjacent fractures whereas $D_{i}$ and $D_{i-1}$ are defined as the distances from the north portal entrance of ESF to the ith and (i-1)th fractures, respectively, and $n f$ is the number of fractures. This is the apparent spacing. It is not the normal distance between the fracture planes and is therefore a rough estimate of the true spacing. These values were not corrected for any possible bias in orientation in the DLS because of lacking fracture orientation information. The mean fracture frequency is given by the inverse of the mean apparent spacing:

$$
\bar{f}=\frac{1}{\bar{s}}
$$

Note that the DLS excludes small fractures that are considered not to connect the conductive fracture networks in the large scale (e.g., site scale).

The borehole data are first processed to normalize for core recovery and corrected for bias in orientation. To correct for orientation bias in data from vertical boreholes, dip distributions are used as follows (modified from Lin et al. 1993 [DIRS 116797], p. 24, Eq. 3-1):

$$
f_{c b}=\frac{\sum_{i} f_{i, 0-19^{\circ} d i p}}{\cos \left(10^{\circ}\right)}+\frac{\sum_{i} f_{i, 20-39^{\circ} d i p}}{\cos \left(30^{\circ}\right)}+\frac{\sum_{i} f_{i, 40-59^{\circ} d i p}}{\cos \left(50^{\circ}\right)}+\frac{\sum_{i} f_{i, 60-90^{\circ} d i p}}{\cos \left(75^{\circ}\right)}
$$

where $f_{c b}$ is the borehole fracture frequency corrected for orientation bias and $f_{i}$ is the fracture frequency corresponding to the range of dip distribution. Because the borehole data include small fractures that are considred not to be connected to the conductive fracture networks in the large scale (e.g., site scale), the borehole fracture frequency values calculated above are scaled to represent larger length fractures on the scale of those characterized in the ESF. A simple correction ratio is used in calculating the final average fracture frequency for each model layer, based on comparisons of ESF data with corresponding vertical boreholes for that model layer:

$$
\begin{aligned}
& \bar{f}=f_{\text {corrected }}=f_{c b} R \\
& R=\left(\frac{f_{E S F}}{f_{\text {borehole }}}\right)_{\text {average }}
\end{aligned}
$$

Two correction factors $R$ were calculated, one for welded units using data for the Topopah Spring middle nonlithophysal hydrogeologic unit (tsw34) and one for nonwelded units using data for the Pah Canyon Tuff in the Paintbrush hydrogeologic unit (ptn25). These two units were selected because they are good representatives of the welded or nonwelded units at the site, respectively, and both ESF and borehole data were available for these two units. 
The fracture intensity is calculated by dividing the trace length of the fracture by the area

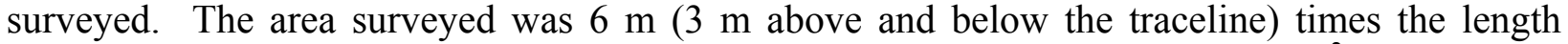
along the tunnel considered for that interval. The average fracture intensity $I\left(\mathrm{~m} / \mathrm{m}^{2}\right)$ is given by:

$$
I=\frac{\sum_{i=1}^{n f} t_{i}}{\text { area }}=\frac{\sum_{i=1}^{n f} t_{i}}{(6 \mathrm{~m})(\text { interval length in meters })}
$$

where $t_{i}$ is trace length in meters for fracture $i$.

Because the survey did not provide the information of the fractures in the third dimension (perpendicular to the drift wall), the fracture interface area is calculated by idealizing the fractures having a disk-like shape with a radii of one-half the trace length of the fracture. The volume for the survey interval is estimated by multiplying the interval length surveyed by the square of the geometric mean of surveyed fracture trace length. The average fracture interface area per volume $A_{f m}\left(\mathrm{~m}^{2} / \mathrm{m}^{3}\right)$ is given by:

$$
A_{f m}=\frac{\sum_{i=1}^{n f} \pi r_{i}^{2}}{\text { volume }}=\frac{\sum_{i=1}^{n f} \pi r_{i}^{2}}{\left(\text { interval length)(geometric mean of trace lengths) }{ }^{2}\right.}
$$

where $r$ is the radius of fracture $i$, or one-half the trace length of fracture $i$.

Fracture apertures are calculated by the cubic law with the fractures fully connected. The fracture aperture $b$ is then given by (Bear et al. 1993 [DIRS 116773], p. 15):

$$
b=\left(\frac{12 k}{\bar{f}}\right)^{1 / 3}
$$

where $k$ is the fracture permeability. The fracture aperture determined in this way is an effective hydraulic aperture (i.e., an aperture consistent with a given permeability observing the cubic law), not a physical aperture. Note that the above equation is modified from Equation 1.2.28 of Bear et al. (1993 [DIRS 116773], p. 15). The $k$ here refers to bulk fracture permeability (i.e., the permeability of the fracture continuum) rather than permeability in a single discrete fracture as defined by Bear et al. (1993 [DIRS 116773], p. 15).

Fitted parameters are required to utilize the van Genuchten equation relating the effective saturation $S_{e}$ and capillary pressure $P_{c}$ [derived from Equations 2, 22, and 24 of "A Closed-Form Equation for Predicting the Hydraulic Conductivity of Unsaturated Soils" (van Genuchten 1980 [DIRS 100610], pp. 892 to 895)]:

$$
P_{c}=\frac{1}{\alpha}\left(S_{e}^{-1 / m}-1\right)^{1 / n}
$$


where $\alpha, m$, and $n=\frac{1}{1-m}$ are the van Genuchten parameters. The effective saturation is defined by:

$$
S_{e}=\frac{S-S_{r}}{S_{s}-S_{r}}
$$

where $S$ is total water saturation, $S_{s}$ is satiated saturation, and $S_{r}$ is residual saturation.

A simplified form of the Young-Laplace equation is assumed to directly calculate the van Genuchten fracture $\alpha\left(\alpha_{f}\right)$ from $b$. Note that the subscript $f$ here and thereafter refers to fractures. The resulting relationship is:

$$
\alpha_{f}=\frac{b}{2 \tau_{\sigma} \cos \theta}
$$

where $\tau_{\sigma}$ is the surface tension of pure water at $25^{\circ} \mathrm{C}(0.072 \mathrm{~N} / \mathrm{m})$ (Lide 2002 [DIRS 160832], p. 6-3) and $\theta$ is the contact angle. Essentially, Equation 6-9 states that van Genuchten $\alpha$ can be estimated as the inverse of the air-entry value, which is often used in the soil science literature (Wang and Narasimhan 1993 [DIRS 106793], p. 374). The contact angle $\theta$ is set to zero (Wang and Narasimhan 1993 [DIRS 106793], p. 329), since the rock is expected to be hydrophilic, and no other specific data are available.

Fracture aperture is calculated from the data of fracture frequency and permeability using Equation 6-7 and the van Genuchten alpha $\left(\alpha_{f}\right)$ is then calculated based on the fracture aperture data using Equation 6-9. The estimated mean apertures are approximately 100 to $400 \mu \mathrm{m}$ except for model layer tcw11, which had a relatively high fracture permeability, resulting in a higher estimated fracture aperture. The fracture van Genuchten alpha parameters $\left(\alpha_{f}\right)$ are on the order of $10^{-3} \mathrm{~Pa}^{-1}$. Large uncertainties exist in these values for the Calico Hills formation and lower units because little or no fracture permeability and fracture frequency data are available.

The aperture-size distribution calculated using Equation 6-7 is further used to calculate the data set of capillary pressure vesus saturation using the Pruess and Tsang's method (Pruess and Tsang 1990 [DIRS 170866], Equation (6) for capillary pressure, and Equation (13) for saturation). The van Genuchten fracture parameter $\left(m_{f}\right)$ is then determined by fitting Equation 6-8a to the data set of capillary pressure vesus saturation above. An $m_{f}$ value of 0.633 , determined from the above method, is given in DTN: LB990501233129.001 [DIRS 106787]. Note that an alternative method to estimate $m_{f}$ is not available in the literature.

The developed fracture properties are given in Table 6-5. 
Table 6-5. Fracture Properties for UZ Model Layers

\begin{tabular}{|c|c|c|c|c|c|c|c|c|c|c|c|c|c|}
\hline \multirow[t]{2}{*}{$\begin{array}{c}\text { UZ } \\
\text { Model Layer }\end{array}$} & \multicolumn{4}{|c|}{ Permeability $\left(\mathrm{m}^{2}\right)$} & \multicolumn{3}{|c|}{ Frequency $\left(m^{-1}\right)$} & \multicolumn{3}{|c|}{$\begin{array}{l}\text { Van Genuchten } \\
\text { Parameter }\end{array}$} & \multicolumn{2}{|c|}{ Porosity } & \multirow[t]{2}{*}{ Afm } \\
\hline & $\mathbf{k}_{\mathrm{G}}$ & $\log \left(k_{G}\right)$ & std & $\mathbf{N}$ & Mean & std & $\mathbf{N}$ & $\alpha\left(\mathrm{Pa}^{-1}\right)$ & $\log (\alpha)$ & m (-) & Mean (-) & Std (-) & \\
\hline tcw11 & 3.0E-11 & -10.52 & - & 2 & 0.92 & 0.94 & 76 & $5.0 \mathrm{E}-3$ & -2.30 & 0.633 & 2.4E-2 & - & 1.56 \\
\hline tcw12 & 5.3E-12 & -11.28 & 0.78 & 80 & 1.91 & 2.09 & 1241 & $2.2 \mathrm{E}-3$ & -2.66 & 0.633 & 1.7E-2 & - & 13.39 \\
\hline tcw13 & $4.5 \mathrm{E}-12$ & -11.35 & 1.15 & 3 & 2.79 & 1.43 & 60 & $1.9 \mathrm{E}-3$ & -2.73 & 0.633 & 1.3E-2 & - & 3.77 \\
\hline ptn21 & $3.2 \mathrm{E}-12$ & -11.49 & 0.88 & 12 & 0.67 & 0.92 & 76 & $2.7 \mathrm{E}-3$ & -2.57 & 0.633 & $9.2 \mathrm{E}-3$ & - & 1.00 \\
\hline ptn22 & 3.0E-13 & -12.52 & 0.20 & 4 & 0.46 & - & - & $1.4 \mathrm{E}-3$ & -2.86 & 0.633 & 1.0E-2 & - & 1.41 \\
\hline ptn23 & 3.0E-13 & -12.52 & 0.20 & 4 & 0.57 & - & 63 & $1.2 \mathrm{E}-3$ & -2.91 & 0.633 & 2.1E-3 & - & 1.75 \\
\hline ptn24 & 3.0E-12 & -11.52 & - & 1 & 0.46 & 0.45 & 18 & $3.0 \mathrm{E}-3$ & -2.53 & 0.633 & 1.0E-2 & - & 0.34 \\
\hline ptn25 & 1.7E-13 & -12.78 & 0.10 & 7 & 0.52 & 0.6 & 72 & $1.1 \mathrm{E}-3$ & -2.96 & 0.633 & $5.5 \mathrm{E}-3$ & - & 1.09 \\
\hline ptn26 & $2.2 \mathrm{E}-13$ & -12.66 & - & 1 & 0.97 & 0.84 & 114 & $9.6 \mathrm{E}-4$ & -3.02 & 0.633 & $3.1 \mathrm{E}-3$ & - & 3.56 \\
\hline tsw31 & 8.1E-13 & -12.09 & - & - & 2.17 & 2.37 & 140 & $1.1 \mathrm{E}-3$ & -2.96 & 0.633 & $5.0 \mathrm{E}-3$ & - & 3.86 \\
\hline tsw32 & 7.1E-13 & -12.15 & 0.66 & 31 & 1.12 & 1.09 & 842 & $1.4 \mathrm{E}-3$ & -2.86 & 0.633 & $8.3 \mathrm{E}-3$ & - & 3.21 \\
\hline tsw33 & $7.8 \mathrm{E}-13$ & -12.11 & 0.61 & 27 & 0.81 & 1.03 & 1329 & $1.6 \mathrm{E}-3$ & -2.80 & 0.633 & $5.8 \mathrm{E}-3$ & - & 4.44 \\
\hline tsw34 & 3.3E-13 & -12.48 & 0.47 & 180 & 4.32 & 3.42 & 10646 & 6.7E-4 & -3.18 & 0.633 & $8.5 \mathrm{E}-3$ & $2.50 \mathrm{E}-03$ & 13.54 \\
\hline $\begin{array}{l}\text { Alternate } \\
\text { tsw34 }\end{array}$ & $1.5 \mathrm{E}-13$ & -12.81 & 0.75 & 180 & & & & & & & & & \\
\hline tsw35 & 9.1E-13 & -12.04 & 0.54 & 31 & 3.16 & - & 595 & $1.0 \mathrm{E}-3$ & -2.99 & 0.633 & $9.6 \mathrm{E}-3$ & - & 9.68 \\
\hline $\begin{array}{l}\operatorname{tsw} 36 \\
\operatorname{tsw} 37\end{array}$ & 1.3E-12 & -11.87 & 0.28 & 19 & 4.02 & - & 526 & $1.1 \mathrm{E}-3$ & -2.96 & 0.633 & $1.3 \mathrm{E}-2$ & - & 12.31 \\
\hline tsw38 & 8.1E-13 & -12.09 & - & - & 4.36 & - & 37 & 8.9E-4 & -3.05 & 0.633 & 1.1E-2 & - & 13.34 \\
\hline tsw39 & 8.1E-13 & -12.09 & - & - & 0.96 & - & 46 & $1.5 \mathrm{E}-3$ & -2.82 & 0.633 & 4.3E-3 & - & 2.95 \\
\hline ch1Ze & $2.5 \mathrm{E}-14$ & -13.60 & - & - & 0.04 & - & 3 & 1.4E-3 & -2.86 & 0.633 & 1.6E-4 & - & 0.11 \\
\hline ch1VI & $2.2 \mathrm{E}-13$ & -12.66 & - & - & 0.10 & - & 11 & 2.1E-3 & -2.69 & 0.633 & $6.1 \mathrm{E}-4$ & - & 0.30 \\
\hline $\begin{array}{l}\text { ch2VI through } \\
\text { ch5VI }\end{array}$ & $2.2 \mathrm{E}-13$ & -12.66 & - & - & 0.14 & - & 25 & $1.9 \mathrm{E}-3$ & -2.73 & 0.633 & 7.7E-4 & - & 0.43 \\
\hline $\begin{array}{l}\text { ch2Ze } \\
\text { through } \\
\text { ch5Ze }\end{array}$ & $2.5 \mathrm{E}-14$ & -13.60 & - & 1 & 0.14 & - & 25 & 8.9E-4 & -3.05 & 0.633 & $3.7 \mathrm{E}-4$ & - & 0.43 \\
\hline ch6 & 2.5E-14 & -13.60 & - & - & 0.04 & - & - & 1.4E-3 & -2.86 & 0.633 & 1.6E-4 & - & 0.11 \\
\hline pp4 & $2.5 \mathrm{E}-14$ & -13.60 & - & - & 0.14 & - & - & $8.9 \mathrm{E}-4$ & -3.05 & 0.633 & 3.7E-4 & - & 0.43 \\
\hline pp3 & $2.2 \mathrm{E}-13$ & -12.66 & - & - & 0.20 & - & - & 1.6E-3 & -2.78 & 0.633 & $9.7 \mathrm{E}-4$ & - & 0.61 \\
\hline pp2 & 2.2E-13 & -12.66 & - & - & 0.20 & - & - & 1.6E-3 & -2.78 & 0.633 & $9.7 \mathrm{E}-4$ & - & 0.61 \\
\hline pp1 & $2.5 \mathrm{E}-14$ & -13.60 & - & - & 0.14 & - & - & 8.9E-4 & -3.05 & 0.633 & 3.7E-4 & - & 0.43 \\
\hline bf3 & $2.2 \mathrm{E}-13$ & -12.66 & - & - & 0.20 & - & - & 1.6E-3 & -2.78 & 0.633 & $9.7 \mathrm{E}-4$ & - & 0.61 \\
\hline bf2 & 2.5E-14 & -13.60 & - & - & 0.14 & - & - & 8.9E-4 & -3.05 & 0.633 & 3.7E-4 & - & 0.43 \\
\hline tr3 & $2.2 \mathrm{E}-13$ & -12.66 & - & - & 0.20 & - & - & 1.6E-3 & -2.78 & 0.633 & $9.7 \mathrm{E}-4$ & - & 0.61 \\
\hline tr2 & $2.5 \mathrm{E}-14$ & -13.60 & - & - & 0.14 & - & - & 8.9E-4 & -3.05 & 0.633 & 3.7E-4 & - & 0.43 \\
\hline
\end{tabular}

Output DTN: LB0205REVUZPRP.001.

$\mathrm{k}_{\mathrm{G}} \quad=$ permeability (geometric mean).

std = standard deviation.

$\mathrm{N}=$ number of samples.

$\alpha=$ fitting parameters for the van Genuchten water potential relationship.

$\mathrm{m}=$ fitting parameters for the van Genuchten water potential relationship.

Afm = fracture-matrix interface area $\left(\mathrm{m}^{2} / \mathrm{m}^{3}\right)$.

"-" indicates that no data are available or dimensionless (in headings). 


\subsubsection{Fracture Porosity}

\subsubsection{General Strategy}

Fracture porosity is herein defined as the effective porosity of fractures in which fluid flow and solute transport take place. In this study, a combination of porosity data derived from gas tracer tests in the ESF, and porosity estimates, based on the geometry of fracture networks, are used to develop representative fracture porosities for the UZ Model layers. The calculation of the fracture porosity is documented in this section and also in the scientific notebook (Wang 2003 [DIRS 161654], SN-LBNL-SCI-215-V1, pp. 43 to 53).

Gas tracer tests were performed in the ESF to obtain estimates of the effective fracture porosity for the Topopah Spring middle nonlithophysal welded tuff, corresponding to the tsw34 model layer (DTN: LB980912332245.002 [DIRS 105593]). Since gas tracer travel times through the fractured rocks are directly related to the storage of the corresponding fracture networks, analyses of tracer breakthrough data can provide reliable estimates of fracture porosity for the model layer tsw34. The porosity of tsw34 can also be estimated based on the fracture geometry observed in the ESF or boreholes using alternative approaches described later.

The alternative approaches use 1-D borehole data or 2-D mapping data to calculate the fracture porosities. The 1-D and 2-D porosities were calculated from the 1-D borehole data and the 2-D mapping data, respectively. A 2-D porosity for a model layer can be estimated using the aperture and the total fracture length per unit area (fracture intensity). The fracture intensity is based on tracer lengths given by the DLS in the ESF and the area enclosing the traces (see Equation 6-5). The equation used to calculate the 2-D porosity is:

$$
\phi_{2-D}=b I
$$

where $I$ is the fracture intensity $\left(\mathrm{m} / \mathrm{m}^{2}\right)$ (DTN: LB990501233129.001 [DIRS 106787]). When no intensity data are available (in cases where the unit does not intersect any portion of the ESF or ECRB Cross-Drift) (BSC 2001 [DIRS 159725], Section 6.1.3), the 1-D porosity can be estimated as follow:

$$
\phi_{1-D}=b \bar{f}
$$

Note that a large degree of uncertainty exists in the estimates based on Equations 6-10 and 6-11 for the following reasons. First, the estimated apertures are hydraulic apertures and may be very different from the average geometric apertures, since they are estimated based on air-permeability data. Second, Equations 6-10 and 6-11 only consider 2-D or 1-D geometric features, while actual fracture networks are three-dimensional. Therefore, direct estimates from these equations may not be reliable. However, it is reasonable to consider that these estimates provide reliable relative ratios of the fracture porosity for different stratigraphic units. Based on these considerations, a fracture porosity is determined by using the corresponding estimate from these equations to determine a ratio of fracture porosity between units. Because porosity, based on analyses of the gas tracer tests, is available for the tsw34 only, this value was used with these ratios to estimate fracture porosity for the other units: 


$$
\phi_{\text {model layer } \mathrm{x}}=\phi_{t s w 34} \frac{\phi_{2-\mathrm{D}, \text { model layer x }}}{\phi_{2-\mathrm{D}, \mathrm{t} \text { sw } 34}} \text { or } \quad \phi_{\text {model layer x }}=\phi_{t s w 34} \frac{\phi_{1-\mathrm{D}, \text { model layer x }}}{\phi_{1-\mathrm{D}, \mathrm{t} \text { sw } 34}}
$$

where $\phi_{t s w 34}$ is fracture porosity for tsw34, estimated from the gas tracer data, and $\phi_{2-D}$ and $\phi_{1-D}$ refer to values calculated using Equations 6-10 and 6-11, respectively. The developed fracture porosity values for the UZ Model layers are given in Table 6-5. These values are on the order of 1 percent.

Note that the overall strategy is essentially a combination of the two general approaches available for estimating fracture porosities in the literature. The first approach is based on field tracer transport data. Researchers outside the Yucca Mountain Project have also used similar approaches. For example, inverse modeling was used to analyze a radially convergent flow tracer test in a fractured chalk formation, resulting in a calibrated fracture porosity of 0.3 percent (National Research Council 1996 [DIRS 139151], pp. 292 to 293). The second general approach is based on the geometry of a fracture network. This approach assumes the fractures under consideration are connected and requires that fracture apertures can be exactly determined. Although a large degree of uncertainty exists in fracture porosity values estimated from this approach (for several reasons), this approach has often been used when field tracer test data are not available. For example, in their review of numerical approaches for modeling multiphase flow in fractured petroleum reservoirs, Kazemi and Gilman (1993 [DIRS 147209], pp. 270 to 271,312 to 313) discuss the determination of fracture porosity, based on fracture geometry data. Considering that gas-tracer-test data are only available for one model layer (tsw34), and a large degree of uncertainty exists when the second approach is used, both approaches provide significantly better estimates for fracture porosity in units through the UZ. A combination of the above two approaches makes the best use of the relevant data.

\subsubsection{Fracture Porosity from Gas Tracer Testing Data}

The estimated fracture porosities (DTN: LB980912332245.002 [DIRS 105593]) were developed based on several simplifications (Figure 6-3): Flow and transport are two-dimensional; dispersion, gas compressibility and matrix diffusion are ignored; and the testing medium is homogeneous. The estimations were made using:

$$
\phi_{f}^{*}=\frac{Q t_{0.5}}{\pi r_{L}{ }^{2} L}
$$

where $\phi_{f}^{*}$ is the estimated fracture porosity, $Q$ is the volumetric withdrawal rate $\left(\mathrm{Q}_{\text {withdrawal }}\right.$ in Figure 6-3), $t_{0.5}$ is the mean travel time of tracer, $r_{L}$ is the distance between the tracer injection and withdrawal zones, and $L$ is the length of injection and withdrawal zone. 


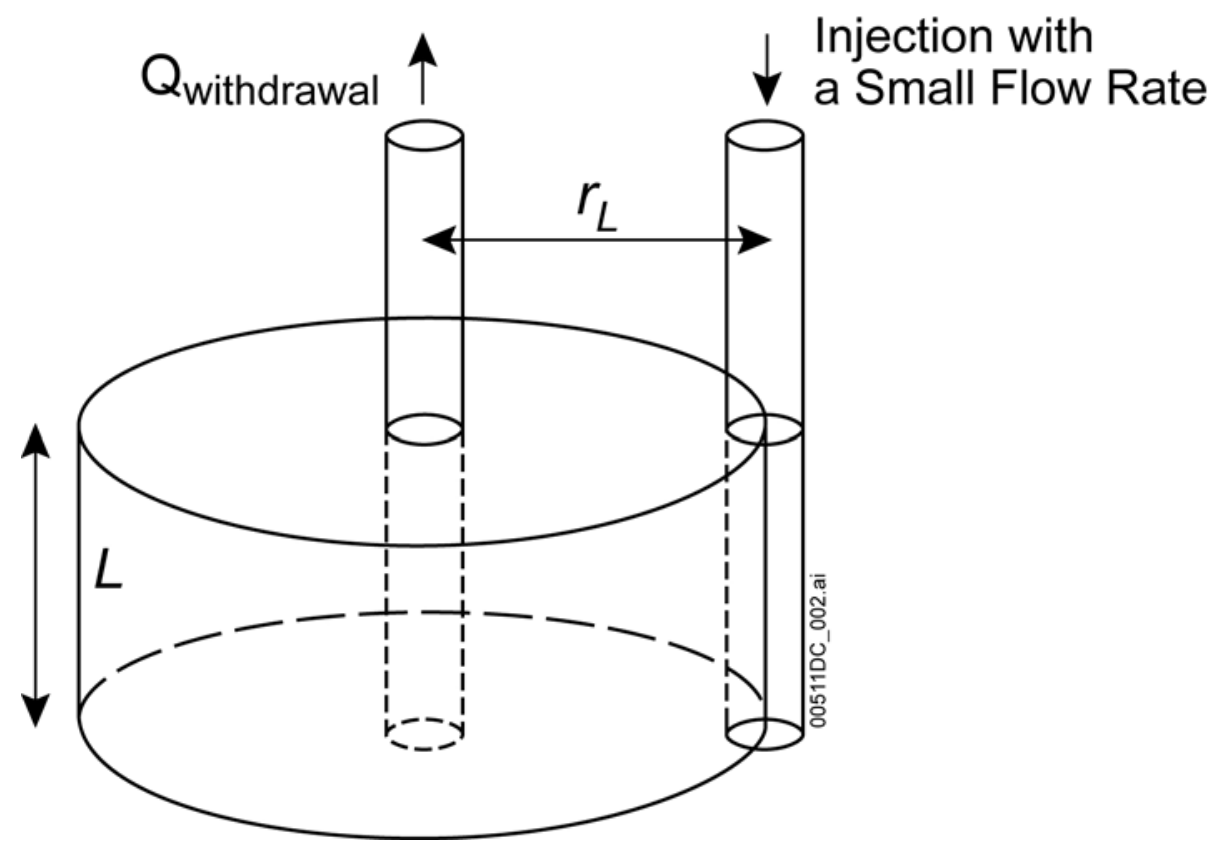

Figure 6-3. A Conceptual Model for Estimating Fracture Porosity Using Gas-Tracer Testing Data

The average fracture porosity, estimated from Equation 6-13 using gas-tracer data collected from the DST block and Niche 3107 , is $1.02 \times 10^{-2}$ (DTN: LB980912332245.002 [DIRS 105593]).

\subsubsection{Effects of Several Factors on Fracture-Porosity Estimation, Based on Gas-Tracer Testing Data}

The estimation of fracture porosity based on Equation 6-13 does not consider the effects of several factors: gas compressibility, heterogeneity, anisotropy, cavities, dispersion, and matrix diffusion. The potential effects of these factors on fracture-porosity estimates are discussed below.

Gas compressibility does not have a significant effect on porosity estimation, because gas-pressure disturbances introduced by the gas-tracer tests are small (relative pressure changes are on the order of several percent), as inferred from Appendix A by Freifeld (2001 [DIRS 161806]).

Heterogeneity within the measurement scale was ignored in estimating fracture porosity, based on Equation 6-13. Therefore, the fracture porosity obtained from a gas-tracer test is an effective porosity of the fracture network within the measurement scale (on the order of several meters). Heterogeneity above the measurement scale is captured by standard deviation of the estimates.

Effects of anisotropy are essentially captured in porosity estimation because different configurations (orientations of the source-sink alignments) were used in gas tracer tests performed in the Drift Scale Test block and Niche 3107. 
Not enough data exist to evaluate the effect of cavities on porosity estimation in detail. However, appropriateness of the estimates can be partially demonstrated by comparing them with those from the other sites without cavities, which will be discussed later on. A discussion of cavity porosities and their estimates for geological units corresponding to the repository horizon is given in Thermal Conductivity of the Potential Repository Horizon Model Report (BSC 2004 [DIRS 169854], p. 81, Table 7-10).

While the dispersion process is not expected to significantly affect the average tracer travel time used to calculate fracture porosity (Equation 6-13), Moench (1989 [DIRS 101146], Figure 2) implies that considering dispersion may result in larger porosity estimates than those determined from Equation 6-13 (Wang 2003 [DIRS 161654], SN-LBNL-SCI-215-V1, p. 53). Therefore, ignoring dispersion may partially compensate for the effects of cavities.

The determination of fracture porosity depends on the tracer travel times. Diffusion of tracer into the matrix delays the breakthrough and causes overestimation of fracture porosity. The effects of matrix diffusion on fracture porosity estimation can be quantified by an analytical solution. Based on mass balance, radial tracer transport in a system (with matrix diffusion) like that shown in Figure 6-3 can be described by the following differential equation (Wang 2003 [DIRS 161654], SN-LBNL-SCI-215-V1, pp. 44 to 45):

$$
\frac{\partial c}{\partial t}+\frac{q_{f w}}{\phi_{f}} \frac{\partial c}{\partial r_{s}}=\left.\frac{A_{f m} \phi_{m} S_{m g} D_{m}}{\phi_{f}} \frac{\partial c_{m}}{\partial x}\right|_{x=0}
$$

with:

$$
\begin{gathered}
q_{f w}=\frac{Q}{2 \pi r_{w} L} \\
r_{S}=\frac{1}{2} \frac{r_{L}^{2}-r^{2}}{r_{w}}
\end{gathered}
$$

and:

$$
D_{m}=D_{0} \tau
$$

where $c$ is the tracer concentration in fractures at a location with a distance $r$ from the withdrawal borehole and at time $t, r_{w}$ is the radius of withdrawal borehole, $\phi_{f}$ is fracture porosity (considering matrix diffusion), $A_{f m}$ is the fracture-matrix interface area per unit volume of bulk rock, $\phi_{m}$ is the matrix porosity, $S_{m g}$ is the gas saturation in the matrix, $D_{0}$ is the molecular-diffusion coefficient for gas in air, $\tau$ is the tortuosity factor, $c_{m}$ is the tracer concentration in the matrix, and $x$ is the distance from the fracture-matrix interface.

Equation 6-14 can be transformed, by defining the lumped parameters (i.e., $A^{0}$ and $T^{0}$ ) as Equations 6-18 and 6-19, into the same mathematic form as Equation 4 of Starr et al. (1985 
[DIRS 101479]), so that the solution to Equation 6-14 can be obtained from it. Under conditions of continuous injection with concentration $c_{0}$, Starr et al. (1985 [DIRS 101479]) derived the solution to their Equation 4 as follows:

$$
\begin{gathered}
\frac{c}{c_{0}}=0 \quad T^{0}<0 \\
\frac{c}{c_{0}}=\operatorname{erfc}\left(\frac{A^{0}}{T^{0}}\right) T^{0}>0
\end{gathered}
$$

where $A^{0}$ and $T^{0}$ are functions of the relevant transport parameters (Starr et al. 1985 [DIRS 101479], p. 1044). The corresponding relations between transport parameters here and those of Starr et al. (1985 [DIRS 101479]) can be easily obtained by comparing Equation 6-14 with their Equation 4. Based on these relations and using $r_{s w}=1 / 2\left(r_{L}^{2}-r_{w}^{2}\right) / r_{w} \cong 1 / 2 r_{L}^{2} / r_{w}$ for $r_{w}$ $<<r_{L}$, expressions for $A^{0}$ and $T^{0}$ at the withdrawal borehole $\left(r=r_{w}\right)$ can be obtained from the corresponding expressions of Starr et al. (1985 [DIRS 101479], p. 1044) and Wang (2003 [DIRS 161654], SN-LBNL-SCI-215-V1, pp. 46 to 47):

$$
\begin{gathered}
A^{0}=\frac{A_{f m} \phi_{m} S_{m g} D_{m}^{1 / 2}\left(\pi L r_{L}^{2}\right)}{2 Q} \\
T^{0}=\left(t-\frac{\phi_{f} r_{L}^{2} \pi L}{Q}\right)^{1 / 2}
\end{gathered}
$$

Note that under continuous (step function) tracer-injection conditions, average tracer travel time $t_{0.5}$ is the time corresponding to 50 percent of the relative tracer concentration in the observed breakthrough curve:

$$
\frac{c\left(t_{0.5}\right)}{c_{0}}=\operatorname{erfc}\left[\frac{A^{0}}{T^{0}\left(t_{0.5}\right)}\right]=0.5
$$

Combining Equations 6-13 with 6-20 through 6-22 yields (i.e., derive $\phi_{f}$ from the relationship, $A^{0} / T^{0}=\beta$ at $\left.\mathrm{t}=\mathrm{t}_{0.5}\right)$ :

$$
\frac{\phi_{f}}{\phi_{f} *}=1-\frac{t_{0.5}}{\phi_{f} *} D_{m}\left[\frac{A_{f m} \phi_{m} S_{m g}}{2 \beta}\right]^{2}
$$

where $\beta$ is a constant $(0.48)$ defined by $\operatorname{erfc}(\beta)=0.5$ and determined from Physical and Chemical Hydrogeology (Domenico and Schwartz 1990 [DIRS 100569], p. 637). The $\phi_{f}$ and $\phi_{f}^{*}$ are identical if the matrix diffusion does not exist $\left(D_{m}=0\right)$, as shown in Equation 6-23. This equation can be used to correct the porosity estimates from Equation 6-13 to consider the effects 
of matrix diffusion. Values for $A_{f m}$ and $\phi_{m}$ (for tsw34) are available from DTN: LB990501233129.001 [DIRS 106787]. The fracture porosity, $\phi_{f}^{*}$, is calculated using Equation 6-13 from DTN: LB980912332245.002 [DIRS 105593]. The average $t_{0.5}$ is $210 \mathrm{~min}$ and average $\phi_{f}^{*}$ is 1.02E-2 (Wang 2003 [DIRS 161654], SN-LBNL-SCI-215-V1, pp. 48 to 49). $S_{m g}(0.1)$ is calculated from the average matrix water saturation within tsw34 (DTN: MO0109HYMXPROP.001 [DIRS 155989]). The value for $D_{m}$ is calculated from Equation 6-17. $D_{0}\left(2.65 \mathrm{E}-5 \mathrm{~m}^{2} / \mathrm{s}\right)$ is determined from the TOUGH User's Guide (Pruess 1987 [DIRS 100684], pp. 5 to 6):

$$
D_{0}=\frac{D_{v a}^{0}}{P}\left(\frac{T+273.15}{273.15}\right)^{\theta}
$$

with the diffusion coefficient in the air, $D_{v a}{ }^{0}=2.3 \mathrm{E}-5 \mathrm{~m}^{2} / \mathrm{s}$ and $\theta=1.80$ for a temperature $(T)$ of $20^{\circ} \mathrm{C}$ and an air pressure $(P)$ of 1 bar. The tortuosity for the gas tracer is estimated from the wellknown relation of Millington and Quirk (1961 [DIRS 139143]):

$$
\tau=\frac{\theta_{g}{ }^{7 / 3}}{\varphi_{m}{ }^{2}}
$$

where $\theta_{g}=\phi_{m} S_{m g}$ is the volumetric gas content in the matrix. Substituting the determined parameter values (including the average $t_{0.5}$ and $\phi_{f}{ }^{*}$ values) into the right hand of Equation 6-23 yields:

$$
\frac{\phi_{f}}{\phi_{f} *}=0.83
$$

This factor is used to consider the effects of matrix diffusion (on average) by multiplying the porosity estimates in DTN: LB980912332245.002 [DIRS 105593] by the factor value of 0.83 . The resultant average fracture porosity for tsw34 is 0.0085 , and the corresponding standard deviation is 2.5E-3. This porosity value is used in Equation 6-12 for determining fracture porosities in other UZ Model layers. The final fracture-porosity estimates are given in Table 6-5. Note that uncertainty exists in the estimated porosity value (Equation 6-26). However, it is difficult to quantify this uncertainty for the given data because site-specific parameter values for calculating this ratio are not available for a tracer test. Nevertheless, as shown in Section 6.1.3.4, the fracture porosity values estimated using Equation 6-26 are reasonable compared with values determined from other sources in the UZ and from other sites. 


\subsubsection{Comparisons with Fracture Porosities Estimated from Other Sources}

To demonstrate the reasonableness of the fracture porosity estimates (given in Table 6-5), these estimates were compared with those determined from other sources in the UZ and from other sites (as fracture analogues).

- Fracture porosities were also estimated from water content-data calculated from water travel times observed from water-release tests in the Tptpmn (tsw34) of the UZ (DTNs: LB980901233124.003 [DIRS 105592]; LB0110LIQR0015.001 [DIRS 156907]). The mean value of the estimates is $\phi_{f}=0.018$ and the standard deviation is 0.014 .

- Seepage Calibration Model and Seepage Testing Data (BSC 2004 [DIRS 171764], Section 6.6.3.3) reports fracture porosity estimates ( 0.7 percent) obtained by inversion of the seepage data collected in the Tptpmn unit. The mean and standard deviation are 0.011 and 0.008 , respectively.

- Fracture porosity was estimated from gas pressure data collected from Apache Leap Research Site (Neuman et al. 2001 [DIRS 160849], p. 320). The estimated mean and standard deviation are 0.014 and 0.0017 , respectively.

- Fracture porosity for a fractured chalk formation, estimated using inversion modeling of a tracer test, was 0.003 (National Research Council 1996 [DIRS 139151], p. 293).

- Fracture porosities estimated from gas tracer tests in the northern Ghost Dance fault in the UZ range were from 0.001 to 0.07 (LeCain et al. 2000 [DIRS 144612], Table 18).

- Estimates based on water travel times observed from water-release tests in Tptpll (tsw35) were 0.013 and 0.067 . The smaller one of these porosity values is believed to mainly result from the fracture network rather than cavities (BSC 2004 [DIRS 170004], Section 6.11.3.1). This value is close to the current estimate for Tptpll (0.0096).

- The calibrated fracture porosity, based on the Alcove 1 infiltration test data, was about 0.028 (Liu et al. 2003 [DIRS 162470], Table 1). The test site is located in the upper portion of the $\mathrm{TCw}$ unit. The calibrated value was close to the current estimate for tcw11 (0.024) (Table 6-5).

These fracture porosity values (obtained using different methodologies, based on different types of data and/or from different sites) are consistent with the current estimates (given in Table 6-5) that are on the order of 1 percent, indicating the reasonableness of these estimates. 


\subsection{MATRIX PROPERTIES}

Matrix properties include matrix permeability and van Genuchten (1980 [DIRS 100610]) parameters used to describe water retention and relative permeability relations. They were determined from laboratory measurements made on core samples from the UZ. Some boreholes from which core samples came are shallow, variously penetrating the TCw, PTn, and top portions of the TSw. Some deep boreholes from which core samples have been collected and analyzed for the entire depth are NRG-6, NRG-7a, SD-7, SD-9, SD-12, UZ-7a, UZ-14, and UZ\#16. Six of these penetrate into the Calico Hills Formation, five penetrate into the Prow Pass Tuff, and one, SD-7, penetrates the Bullfrog and Tram Tuffs. Core samples have also been collected from portions of two other deep boreholes: SD-6 and WT\#24. The associated DTNs and their use can be found in the description of the relevant Excel files in Appendix A of this report.

Sample collection and laboratory measurement methodologies, as well as estimates of uncertainty, are described by Flint (1998 [DIRS 100033], pp. 11 to 19) and Rousseau et al. (1999 [DIRS 102097], pp. 125 to 153). Core samples are grouped and analyzed according to the hydrogeologic units characterized by Flint (1998 [DIRS 100033], pp. 19 to 46) and detailed in a Scientific Notebook (Wang 2003 [DIRS 161654], SN-LBNL-SCI-003-V2, pp. 57 to 83). Table 6-1 shows these hydrogeologic units in relation to the lithostratigraphy of GFM2000 and the UZ Model layers.

The calculation of matrix properties is described in a scientific notebook (Wang 2003 [DIRS 161654], SN-LBNL-SCI-003-V2, pp. 57 to 83). Calculated matrix properties are given in Table 6-6. The Excel files used to perform these calculations are listed and described in Appendix A. The matrix porosity and permeability values are calculated with hydroprops fin.xls (Appendix A). The unsaturated hydraulic properties are calculated with $M R C_{-} Q_{-} T C w_{-}$fin.xls, $M R C \_Q \_P T n \_f i n . x l s, M R C \_Q \_T S w \_$fin.xls, MRC_Q_CHCF_fin.xls, vG_Summary_fin.xls, and PV2 deep borehole data.xls (Appendix A). 
Table 6-6. Matrix Properties Developed from Core Data

\begin{tabular}{|c|c|c|c|c|c|c|c|c|c|c|c|c|c|c|c|c|c|c|}
\hline HGU & $\phi$ & $\sigma$ & $\mathbf{N}$ & SE & $\begin{array}{c}\text { Upscaled } \\
k \\
{\left[\mathrm{~m}^{2}\right]} \\
\end{array}$ & $\begin{array}{c}\text { Upscaled } \\
\log (\mathbf{k}) \\
{\left[\log \left(\mathrm{m}^{2}\right)\right]}\end{array}$ & $\sigma_{\log (k)}$ & $\mathbf{N}$ & Nd & $S E_{\log (k)}$ & $\begin{array}{c}1 / \alpha \\
{[\mathrm{Pa}]}\end{array}$ & $\begin{array}{l}\log (1 / \alpha) \\
{[\log (P a)]}\end{array}$ & $S E_{\log (1 / a)}$ & m & SE & $\mathrm{S}_{\mathrm{r}}$ & $\eta$ & SE \\
\hline CCR \& CUC & 0.241 & 0.073 & 124 & 0.007 & 4.7E-15 & -14.33 & 0.47 & 3 & 0 & 0.27 & $8.27 \mathrm{E}+4$ & 4.918 & 0.279 & 0.388 & 0.085 & 0.02 & 3.47 & 17.88 \\
\hline $\mathrm{CW}$ & 0.088 & 0.032 & 694 & 0.001 & $6.4 \mathrm{E}-20$ & 9.20 & 2.74 & 15 & 25 & 0.43 & $5.46 \mathrm{E}+5$ & 5.737 & 178 & 0.280 & 0.045 & 0.20 & 12.29 & 19.35 \\
\hline CMW & 0.200 & 0.055 & 96 & 0.006 & $1.8 \mathrm{E}-16$ & -15.74 & 2.38 & 5 & 1 & 0.97 & $2.50 \mathrm{E}+5$ & 5.398 & 88 & 0.259 & 0.042 & 0.31 & 6.08 & 0.00 \\
\hline CNW & 0.387 & 0.069 & 104 & 0.007 & 4.0E-14 & -13.40 & 2.05 & 10 & 0 & 0.65 & $2.03 E+4$ & 08 & 199 & 0.245 & 0.032 & 0.24 & -2.58 & 0.33 \\
\hline BT4 & 0.428 & 0.100 & 58 & 0.013 & 4.1E-13 & -12.39 & 1.41 & 11 & 0 & 0.43 & $4.55 E+3$ & 3.658 & 0.174 & 0.219 & 0.019 & 0.13 & -0.26 & 1.17 \\
\hline TPY & 0.233 & 0.057 & 39 & 0.009 & $1.3 \mathrm{E}-15$ & -14.90 & 0.64 & 2 & 0 & 0.46 & $7.63 E+4$ & 883 & 379 & 0.247 & 0.064 & 0.07 & 3.46 & 6.73 \\
\hline BT3 & 0.413 & 0.082 & 73 & 0.010 & 1.3E-13 & -12.87 & 1.09 & 11 & 1 & 0.31 & $8.90 E+3$ & 50 & 088 & 0.182 & 0.008 & 0.14 & -0.56 & 0.49 \\
\hline TPP & 0.498 & 0.041 & 159 & 0.003 & 1.1E-13 & -12.96 & 0.39 & 11 & 0 & 0.12 & $2.12 \mathrm{E}+4$ & 4.325 & 0.104 & 0.300 & 0.023 & 0.06 & 0.26 & 0.42 \\
\hline BT2 & 0.490 & 0.095 & 176 & 0.007 & 6.7E-13 & -12.17 & 1.12 & 21 & 0 & 0.24 & $1.74 \mathrm{E}+4$ & 4.239 & 0.170 & 0.126 & 0.013 & 0.05 & -2.64 & 0.67 \\
\hline TC & 0.054 & 0.036 & 75 & 0.004 & 4.4E-17 & 36 & 3.02 & 6 & 5 & 0.91 & $2.71 \mathrm{E}+5$ & 32 & 310 & 0.218 & 0.054 & 0.21 & 6.14 & 7.21 \\
\hline TR & 0.157 & 0.030 & 449 & 0.001 & $3.2 \mathrm{E}-16$ & -15.50 & 0.94 & 46 & 1 & 0.14 & $9.43 \mathrm{E}+4$ & 4.974 & 0.116 & 0.290 & 0.025 & 0.07 & 5.00 & 17.49 \\
\hline TUL & 0.155 & 0.030 & 438 & 0.001 & $2.8 \mathrm{E}-17$ & -16.56 & 1.61 & 37 & 12 & 0.23 & $1.75 E+5$ & 5.244 & 0.111 & 0.283 & 0.024 & 0.12 & 7.06 & 17.98 \\
\hline TMN & 0.111 & 0.020 & 277 & 0.001 & 4.5E-19 & -18.34 & 0.97 & 74 & 35 & 0.09 & $1.40 \mathrm{E}+6$ & 6.147 & 0.108 & 0.317 & 0.042 & 0.19 & 10.90 & 19.28 \\
\hline TLL & 0.131 & 0.031 & 502 & 0.001 & 3.7E-17 & -16.44 & 1.65 & 51 & 24 & 0.19 & $6.01 \mathrm{E}+4$ & 79 & 0.521 & 0.216 & 0.061 & 0.12 & 6.27 & 17.23 \\
\hline TM2 \& & 0.103 & 0.025 & 298 & 001 & 2 & -19.63 & 3.67 & 21 & 42 & 46 & $3.40 \mathrm{E}+6$ & 6.532 & 97 & 442 & 0.073 & 0.20 & 14.48 & 1.25 \\
\hline PV3 & 0.043 & 0.040 & 125 & 0.004 & $9 \mathrm{E}-18$ & 17.0 & 1.57 & 16 & 2 & .37 & $1.00 \mathrm{E}+6$ & 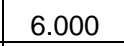 & 78 & .286 & 0.065 & 0.42 & .04 & 8.53 \\
\hline PV2a & 0.275 & 0.096 & 13 & 0.027 & a & 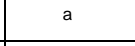 & a & a & a & a & $2.17 \mathrm{E}+5$ & 5.336 & 156 & 0.059 & 0.007 & 0.36 & 5.03 & 15.63 \\
\hline PV2v & 0.229 & 0.132 & 40 & 0.021 & 4.3E-13 & -12.37 & 1.38 & 16 & 0 & 0.34 & $1.94 \mathrm{E}+4$ & 4.287 & 0.042 & 0.293 & 0.011 & 0.13 & -0.19 & 0.23 \\
\hline BT1a & 0.285 & 0.051 & 46 & 0.008 & 3.5E-17 & -16.45 & 2.74 & 9 & 1 & 0.87 & $4.72 \mathrm{E}+6$ & 6.674 & 0.183 & 0.349 & 0.073 & 0.38 & 7.39 & 18.61 \\
\hline BT1v & 0.331 & 0.091 & 76 & 0.010 & $2.1 \mathrm{E}-13$ & -12.67 & 1.11 & 35 & 0 & 0.19 & $1.35 \mathrm{E}+4$ & 4.131 & 0.049 & 0.240 & 0.008 & 0.06 & -2.07 & 0.23 \\
\hline CHV & 0.346 & 0.049 & 130 & 0.004 & 1.6E-12 & 1101 & 1.62 & 46 & 0 & 0.24 & $3.39 E+3$ & 3530 & 0.094 & 0.158 & 0.008 & 0.06 & -3.80 & 0.23 \\
\hline $\mathrm{CH}_{2}$ & 22 & 0.048 & 520 & 0.002 & 0 & (2) & 0.91 & 99 & 17 & 10 & $4.45 E+5$ & 5.649 & 94 & 57 & 0.022 & 0.26 & 30 & 8.10 \\
\hline BTa & 0.271 & 0.046 & 73 & 0.005 & $2 E-19$ & 18.0 & 2.05 & 9 & 8 & 0.50 & $6.42 \mathrm{E}+6$ & 6.808 & 43 & 0.499 & 0.036 & 0.36 & 11.87 & 21.01 \\
\hline BTV & b & b & $\mathrm{b}$ & b & b & b & b & $\mathrm{b}$ & b & b & $5.04 \mathrm{E}+4$ & 4.703 & 0.207 & 0.147 & 0.020 & h & -0.87 & 14.77 \\
\hline PP4 & 0.321 & 0.047 & 52 & 0.006 & $1.5 \mathrm{E}-16$ & 5.81 & 2.74 & 6 & 2 & 0.97 & $5.00 E+5$ & 5.699 & 0.401 & 0.474 & 0.224 & 0.29 & 7.13 & 19.55 \\
\hline PP3 & 0.318 & 0.032 & 168 & 0.002 & $6.4 \mathrm{E}-15$ & 20 & 0.75 & 51 & 0 & 0.11 & $1.32 \mathrm{E}+5$ & 20 & 0.084 & 0.407 & 0.031 & 0.08 & 3.37 & 18.01 \\
\hline PP2 & 0.221 & 0.058 & 127 & 0.005 & $5.4 \mathrm{E}-17$ & 27 & 1.18 & 34 & 3 & 19 & $6.22 \mathrm{E}+5$ & 4 & 147 & 309 & 0.041 & 0.10 & .69 & 8.09 \\
\hline PP1 & 0.297 & 0.043 & 280 & 0.003 & 8.1E-17 & -16.09 & 1.52 & 27 & 1 & 0.29 & $1.13 E+5$ & 5.052 & 234 & 0.272 & 0.036 & 0.30 & 6.05 & 7.63 \\
\hline BF3/TR3 & 0.175 & 0.104 & 126 & 0.009 & $1.1 \mathrm{E}-15$ & -14.95 & 1.64 & 7 & 1 & 0.58 & $8.94 \mathrm{E}+4$ & 4.951 & 931 & 0.193 & 0.117 & 0.11 & 3.11 & 16.20 \\
\hline BF2 & 0.234 & 0.049 & 40 & 0.008 & $c_{1}$ & $c_{1}$ & c & c & c & $c$ & $8.46 \mathrm{E}+6$ & 6.927 & 0.032 & 0.617 & 0.070 & 0.21 & 8.86 & 21.17 \\
\hline
\end{tabular}

Output DTN: LB0207REVUZPRP.002.

${ }^{a}$ BT1a was used as an analog for permeability because only one permeability data point is available for PV2a.

${ }^{b}$ BT1v was used as an analog for porosity, residual saturation, and permeability because only one sample is available for BTV.

${ }^{c}$ PP1 was used as an analog for permeability because only one measurable permeability data point is available for BF2.

$\mathrm{k}$ is permeability.

$\sigma \quad$ is standard deviation.

$n \quad$ is number of samples.

$\phi \quad$ is porosity.

$\mathrm{Nd}$ is number of samples with undetectable permeability measurements.

$\alpha \quad$ is fitting parameters for the van Genuchten water potential relationship.

$m$ is fitting parameters for the van Genuchten water potential relationship.

SE is standard error.

$\mathrm{S}_{\mathrm{r}} \quad$ is residual liquid saturation.

$\eta \quad$ is defined in Equation 6-34. Relation between HGU and UZ model layers is given in Table 6-2.

$\mathrm{HGU}=$ hydrogeologic units. 


\subsubsection{Matrix Permeability}

Matrix permeability was measured on core samples from several boreholes (including SD-6 and WT\#24) at Yucca Mountain. Measurements are available for layers from the CUC down to the BF2 (Table 6-6). Two different permeameters were used to measure permeability, with the detection limit of the first higher than the second. Most of the samples were tested using the first permeameter; the second was used to test some new samples and retest some old samples originally tested using the first permeameter, including some with permeabilities too low to measure (nondetect results). When the same sample was tested on both permeameters, the permeability measured on the one with the lower detection limit was used since it was expected to result in a more reliable measurement.

The measured data are presented in terms of saturated hydraulic conductivity $(\mathrm{m} / \mathrm{s}), K$, which is converted to permeability $\left(\mathrm{m}^{2}\right), k$, by the following relationship:

$$
k=\frac{K \mu_{w}}{g \rho_{w}}
$$

where $\mu_{w}$ is the viscosity of water $\left(0.001 \mathrm{~N} \mathrm{~s} / \mathrm{m}^{2}\right), g$ is the acceleration of gravity $\left(9.81 \mathrm{~m} / \mathrm{s}^{2}\right)$, and $\rho_{w}$ is the density of water $\left(998 \mathrm{~kg} / \mathrm{m}^{3}\right)$. These parameter values correspond to a temperature of $25^{\circ} \mathrm{C}$ (a typical room temperature at which the hydraulic conductivities were measured) (Lide 2002 [DIRS 160832], p. 6-3).

Permeability is considered to be a lognormally-distributed quantity (Gelhar 1993 [DIRS 101388], p. 2). Therefore, the geometric mean was used to represent the average permeability of each model layer. The standard deviation of the log-transformed permeabilities, $\log (k)$, is used as the basis for uncertainty, which is detailed below. Where there are no nondetect measurements in the data set for a layer, the calculation of the average and standard deviation of the data is simple. When nondetect measurements are present, they must be taken into account, because they may represent important information about the extent of the lognormal distribution below the detection limit. They are taken into account as follows:

- Data points, including nondetects, are ranked and assigned a percentile.

- The data points are fitted to a lognormal distribution, based on their percentile ranking. The fitting parameters are $k_{g}$, the geometric mean of the permeability data, and $\sigma_{\log (k)}$, the standard deviation of the log-transformed permeability data.

The geometric mean permeabilities calculated above represent the average behavior of the core-scale samples. For a given model layer, this averaged permeability can be very different from the effective matrix permeability used to represent large-scale water flow and solute transport due to scale effects (e.g., Paleologos et al. 1996 [DIRS 105736], Figure 4, p. 1337). While many upscaling methods are available in the literature, one method for highly 
heterogeneous porous media is described by the following expression (Paleologos et al. 1996 [DIRS 105736], p. 1336):

$$
k_{e}=k_{g} \exp \left[\sigma_{\ln (k)}^{2}(1 / 2-D)\right]
$$

where $k_{e}$ is the effective permeability, $k_{g}$ is the geometric mean of small (core) scale permeability, $\sigma_{\ln (k)}{ }^{2}$ is the variance of the natural $\log$-transformed permeability, and $D$ is a function of spatial dimensions (e.g., 2-D and 3-D) and the correlation scale of $\ln (k)$. Note that the geometric mean permeability is not the same as the effective permeability in a general case. For a 3-D isotropic problem, $D=1 / 3$ when the characteristic size of a flow domain under consideration (say, a model layer) is much larger than the correlation length (Paleologos et al. 1996 [DIRS 105736], p. 1336). For a site-scale model layer, these conditions are approximately satisfied. In this case, Equation 6-28 can be rewritten as:

$$
\log \left(k_{e}\right)=\log \left(k_{g}\right)+0.38 \sigma_{\log (k)}^{2}
$$

where $\sigma_{\log (k)}{ }^{2}$ is the variance of the log-transformed permeability.

In these layers, the amount of upscaling predicted by Equation 6-28 is as large as five orders of magnitude. An upper limit of 1.5 orders-of-magnitude upscaling is imposed on layers CUL and CW, CMW, CNW, TC, TM2 and TM1, and BT1a and PP4 (Assumption 2, Section 5). For other layers, the amount of upscaling predicted by Equation 6-28 is less than 1.5 orders of magnitude. Use of this limiting scheme is based mainly on the following consideration: Equation 6-28 was developed for a porous medium (single continuum) and can only be considered as an approximation for a dual-continuum system. For example, the existence of fractures, which may act as a capillary barrier, can increase tortuosity of liquid water flow in the matrix and therefore reduce the effective permeability compared to the case without fractures. This situation is not considered in Equation 6-28.

\subsubsection{Porosity}

Matrix porosity was also measured on core samples from the UZ. Porosity was determined after drying samples in a $105^{\circ} \mathrm{C}$ oven for at least 48 hours to obtain a standard dry weight (Flint 1998 [DIRS 100033], p. 17). Porosity is considered a normally distributed quantity, so the arithmetic mean of core measurements and standard deviation were used to characterize the porosity for a model layer.

\subsubsection{Matrix van Genuchten Parameters}

The relationships described by van Genuchten (1980 [DIRS 100610], pp. 892 to 893) were used to characterize unsaturated flow in the matrix of Yucca Mountain. Use of the water-potentialversus-saturation relationship allows the prediction of the relative permeability relationship. The predicted relative permeability is compared with permeability data where available.

The van Genuchten parameters are $S_{s}$ (satiated saturation), $S_{r}$ (residual saturation), $\alpha$, and $m$. Satiated saturation is set to be 1.0 because residual gas saturation in the UZ is negligible. Residual saturation is calculated based on two porosity measurements as described below. With 
satiated and residual saturation fixed, $\alpha$ and $m$ are adjusted to fit water potential and saturation data.

\subsubsection{Residual Saturation}

Residual saturation was determined from relative humidity $(\mathrm{RH})$ porosity and total porosity. $\mathrm{RH}$ porosity was measured after drying a sample for 48 hours in a $60^{\circ} \mathrm{C}$ and 65 percent relative humidity oven. This process is designed to remove water from the pores that contributes to flow, leaving only bound water and water in the smallest pores (Flint 1998 [DIRS 100033], p. 17). Layer average values for RH porosity are calculated in the same manner as total porosity (see Section 6.2.2). The layer average values of RH porosity are subtracted from the layer average values of total porosity to provide an estimate of residual water content (i.e., the amount of water left in the pores and bound to the minerals after relative permeability (or hydraulic conductivity) has been reduced to zero). Residual saturation was calculated by dividing the residual water content by total porosity.

\subsubsection{Matrix $\alpha$ and $m$}

Desaturation data (water potential and saturation) from a number of samples (at least one for each layer) were measured while a core sample was drying. DTNs associated with these data and their uses are given in descriptions of Excel files MRC_Q_TCw_fin.xls, $M R C \_Q \_P T n \_f i n . x l s, M R C \_Q \_T s w \_$fin.xls, and $M R C \_Q \_C H C F \_$fin.xls (Appendix A of this report). These data were used to calculate the $\alpha$ and $m$ parameters for each layer by fitting to Equation 6-8. The best-fit parameters were obtained by minimizing the sum of the squared saturation residuals:

$$
\sum_{i=1}^{n} r_{i}^{2}=\sum_{i=1}^{n}\left(S_{i}-S\left(\Psi_{i}\right)\right)^{2}
$$

where $r_{i}$ is a saturation residual, $\mathrm{n}$ is the number of saturation and water potential data pairs for a layer, $S_{i}$ is a saturation data point, and $S\left(\Psi_{i}\right)$ is the saturation predicted by the van Genuchten relationship for water potential, $\Psi_{i}$.

The uncertainty or standard error of $\alpha$ and $m$ is given by the diagonal terms of the covariance matrix:

$$
\boldsymbol{C}=s_{0}^{2}\left(\boldsymbol{J}^{\boldsymbol{T}} \boldsymbol{J}\right)^{-1}
$$

where $\boldsymbol{C}$ is the covariance matrix, $s_{0}{ }^{2}$ is the error variance, $\boldsymbol{J}$ is the Jacobian matrix, and $\boldsymbol{J}^{\boldsymbol{T}}$ denotes the transpose of the matrix $\boldsymbol{J}$. It should be noted that standard error, $S E$, can be related to the standard deviation, $\sigma$, which is given for other properties, by:

$$
S E=\sigma / \sqrt{N}
$$

where $\mathrm{N}$ is the number of samples. 


\subsubsection{Matrix Relative Permeability}

DTNs associated with data (used for calculating relative permeability) and their uses are given in descriptions of Excel files $M R C \_Q \_T C w \_$fin.xls, MRC_Q_PTn_fin.xls, MRC_Q_Tsw_fin.xls, $M R C \_Q \_C H C F \_$fin.xls, and $V G \_$Summary_fin.xls (Appendix A of this report). According to van Genuchten (1980 [DIRS 100610], p. 893), relative permeability $\left(k_{r}\right)$ can be related to effective water saturation $\left(S_{e}\right)$ as:

$$
k_{r}=S_{e}^{1 / 2}\left\{\left[1-\left(1-S_{e}^{1 / m}\right)\right]^{m}\right\}^{2}
$$

However, recent studies indicate that a more general expression for relative permeability is (Schaap and Leij 2000 [DIRS 160841], pp. 843 to 844):

$$
k_{r}=S_{e}^{\eta}\left\{\left[1-\left(1-S_{e}^{1 / m}\right)\right]^{m}\right\}^{2}
$$

where $\eta$ is an empirical constant. Many studies show that $\eta$ is not 0.5 , as assumed by the standard van Genuchten (1980 [DIRS 100610]), but varies over quite a large range (Schaap and Leij 2000 [DIRS 160841], pp. 843 to 844). This is consistent with the matrix relative permeability data collected from the UZ.

To determine an $\eta$ estimate for a UZ model layer, the following equation was used to fit the unsaturated conductivity $(K)$ data collected within the model layer:

$$
\frac{K\left(S_{e}\right)}{K\left(S_{0}\right)}=\frac{S_{e}{ }^{\eta}\left\{\left[1-\left(1-S_{e}{ }^{1 / m}\right)\right]^{m}\right\}^{2}}{S_{0}{ }^{\eta}\left\{\left[1-\left(1-S_{0}\right)^{1 / m}\right]^{m}\right\}^{2}}
$$

$K\left(S_{0}\right)$ is the conductivity at a saturation $S_{0}$, which is selected to be close to one. Equation 6-35 is derived by writing Equation 6-34 for a general value of $S_{e}$ and for $S_{e}=S_{0}$. The fitted $\eta$ values are reported in Table 6-6 for different model layers (Wang 2003 [DIRS 161654], SN-LBNL-SCI-003-V2, pp. 63 to 83). They range from -2.64 to 14.48 , which are consistent with those cited by Schaap and Leij (2000 [DIRS 160841], p. 844). Note that directly fitted $\eta$ values are available only for hydrogeologic units CMW, CNW, BT4, BT3, TPP, BT2, PV2v, BT1v, and CHV where unsaturated hydraulic conductivity data are collected (Table 6-6). For other units, the following empirical relation is used to estimate the $\eta$ values:

$$
\eta=A m-B \log (k)+C
$$

and the corresponding standard errors are estimated by:

$$
S E_{\eta}=S E_{A} m-S E_{B} \log (k)+S E_{C}
$$

where $k$ is absolute permeability and $A(8.14), B(1.99)$, and $C(-28.24)$ are empirical parameters determined by fitting Equation 6-36 to $\eta$ values for hydrogeologic units CMW, CNW, BT4, BT3, TPP, BT2, PV2v, BT1v and CHV where unsaturated hydraulic conductivity data are 
collected (Wang 2003 [DIRS 161654], SN-LBNL-SCI-003-V2, pp. 63 to 83). $S E_{A}, S E_{B}$, and $S E_{C}$ are the standard errors for $A, B$, and $C$, respectively, and determined from the curve fitting (Wang 2003 [DIRS 161654], SN-LBNL-SCI-003-V2, p. 82). Values calculated from Equations 6-36 and 6-37 are reported in Table 6-6.

A comparison between the currently obtained results based on Equation 6-34 and the van Genuchten relative permeability-saturation relation, Equation 6-33 can be easily made with:

$$
\frac{k_{r}\left(S_{e}\right)}{k_{r, V G}\left(S_{e}\right)}=S_{e}{ }^{\eta-0.5}
$$

where subscript "VG" refers to relative permeability obtained from the van Genuchten relation, Equation 6-33. Equation 6-38 is derived from Equations 6-33 and 6-34. Since estimated $\eta$ values were very different from 0.5 for many model layers (Table 6-6), relative permeabilities predicted with standard van Genuchten relation, Equation 6-33, have considerable errors, especially for low saturations. The errors become insignificant for saturations close to one, which is the case for welded units under ambient conditions. Also, note that a large degree of uncertainty in estimated $\eta$ values exists because of data limitations. Therefore, the standard van Genuchten relation is still used in flow and transport modeling studies of the UZ.

\subsection{FAULT PROPERTIES}

The UZ Model represents faults as having four layers defined by the major HGUs: TCw, PTn, TSw, and $\mathrm{CHn} / \mathrm{CFu}$. The constituent sublayers of these HGUs are shown in Table 6-1. Fault, fracture, and thermal properties are calculated for these four layers. Each HGU has been assumed to be approximately uniform within faults, because data to characterize faults are very limited. Matrix hydraulic properties in faults, however, are assigned the same values as those of the corresponding HGUs.

Direct measurements of fault-specific properties were limited to air-injection tests performed in Alcoves 2, 6, and 7, which are also called the Bow Ridge fault alcove, the North Ghost Dance fault access drift, and the South Ghost Dance fault access drift, respectively. Analysis of crosshole tests run in the Bow Ridge fault alcove (LeCain 1998 [DIRS 100052], pp. 21 to 22) and the North Ghost Dance fault access drift (DTN: GS990883122410.002 [DIRS 135230]; LeCain et al. 2000 [DIRS 144612]) gave the best estimates of fracture permeability in the TCw and TSw fault layers, respectively.

Other fault properties were calculated as averages of nonfault layers. Some layers are much thicker than others, and thus the properties of those layers should be weighted more heavily when calculating the fault properties. Properties were weighted by their respective average layer thickness. Porosity was arithmetically averaged because its differences between model layers within each HGU are not significant: 


$$
p_{a}=\frac{\sum_{i=1}^{n} p_{i} L_{i}}{\sum_{i=1}^{n} L_{i}}
$$

where $p_{a}$ is the weighted arithmetic average property (porosity), $n$ is the number of layers being averaged, $p_{i}$ is the property for layer $i$, and $L_{i}$ is the thickness of layer $i$. The fracture-matrix interface areas are also calculated using Equation 6-39. Because permeability is generally lognormally distributed (Gelhar 1993 [DIRS 101388], p. 2), a harmonic averaging method (Equation 6-38) is used to calculate the average permeability for each HGU:

$$
p_{h}=\frac{\sum_{i=1}^{n} L_{i}}{\sum_{i=1}^{n} \frac{L_{i}}{p_{i}}}
$$

where $p_{h}$ is the weighted harmonic average property (permeability). Layer thickness is estimated as the average (arithmetic) layer thickness over the GFM2000 model (DTN: MO0012MWDGFM02.002 [DIRS 153777]) area. Another consideration for using Equation 6-40 is that it is exact when the flow direction is perpendicular to interfaces between model layers. This is approximately the case for the UZ, because the flow direction is mainly vertical.

In principle, a more rigorous way to estimate the fault (fracture) properties is to correlate them with geologic information specific to each fault being modeled and to individual locations within each fault, such as amount of fault offset, width of the disturbed zone, and presence of contacts with significant property changes. This alternative approach, however, requires developing relationships between hydraulic properties and geologic information that cannot be reliably estimated with available data pertaining to fault properties.

Fracture permeability for the $\mathrm{TCw}$ and $\mathrm{TSw}$ fault layers was derived from by the crosshole air-injection tests described above. Permeability for the PTn and $\mathrm{CHn} / \mathrm{CFu}$ fault layers was calculated by scaling the weighted average bulk-rock fracture permeability. As with the fault matrix permeability, equivalent fracture permeability was calculated for all four fault layers using the weighted harmonic mean of permeabilities for the corresponding nonfault model layers. The average (geometric mean) ratio of the measured permeability to the calculated equivalent permeability for layers TCw and TSw was calculated (Ahlers 2000 [DIRS 155853], pp. 124 to 125). This factor multiplies the calculated equivalent permeability of the PTn and $\mathrm{CHn} / \mathrm{CFu}$ layers to scale them upward. This process is equivalent to the process used to scale bulk-rock matrix $\alpha$, which is explained in Section 6.2.

Fracture spacing for each major HGU, equal to the inverse of fracture frequency, was calculated using the weighted arithmetic mean. Again, it can be shown that the weighted arithmetic mean of $1 / p_{i}$ is equal to the harmonic mean of $p_{i}$, so the weighted harmonic mean of frequency is used to calculate the equivalent frequency for the faults. 
Fault fracture aperture was calculated as in Section 6.1.2 (using Equation 6-7), based on the cubic law and the fault permeabilities and frequencies.

Fault fracture porosity was determined by scaling the weighted arithmetic mean of bulk-rock fracture porosity, with the scaling factor, the ratio of the above fault fracture aperture to mean bulk-rock fracture aperture. The mean bulk-rock fracture aperture was calculated as the weighted arithmetic average of fracture aperture.

The fracture van Genuchten $m\left(m_{f}\right)$ is taken as 0.633 as for other fractures (see Section 6.1). The fracture van Genuchten $\alpha\left(\alpha_{f}\right)$ is calculated based on the fracture aperture, using Equation 6-9 as documented in Section 6.1.2.

The fracture-to-matrix connection area for the faults was approximated as the weighted arithmetic mean of the bulk-rock fracture-to-matrix connection area. The rationale for the development of fault properties is documented in a Scientific Notebook (Ahlers 2000 [DIRS 155853], pp. 117 to 127,145 to 146). Table 6-7 presents the calculated fault fracture properties.

Table 6-7. Calculated Fault Fracture Properties

\begin{tabular}{|l|c|c|c|c|c|c|c|}
\hline Major Unit & Fault Layer & $\begin{array}{c}\text { Permeability } \\
\left(\mathbf{m}^{\mathbf{2}}\right)\end{array}$ & $\begin{array}{c}\text { Porosity } \\
(-\mathbf{)}\end{array}$ & $\begin{array}{c}\text { Frequency } \\
\left(\mathbf{m}^{-1}\right)\end{array}$ & $\boldsymbol{\alpha}_{\mathbf{f}}\left(\mathbf{P a}^{-1}\right)$ & $\mathbf{m}_{\mathbf{f}}(\mathbf{-})$ & $\begin{array}{c}\text { Interface area } \\
\left(\mathbf{m}^{\mathbf{2}} / \mathbf{m}^{\mathbf{3}}\right)\end{array}$ \\
\hline TCW & tcwf & $2.7 \mathrm{E}-11$ & $2.9 \mathrm{E}-2$ & 1.9 & $3.8 \mathrm{E}-3$ & 0.633 & 12.9 \\
\hline PTn & ptnf & $3.1 \mathrm{E}-12$ & $1.1 \mathrm{E}-2$ & 0.54 & $2.8 \mathrm{E}-3$ & 0.633 & 1.3 \\
\hline TSW & tswf & $1.5 \mathrm{E}-11$ & $2.5 \mathrm{E}-2$ & 1.7 & $3.2 \mathrm{E}-3$ & 0.633 & 8.7 \\
\hline CHn/CFu & chnf & $3.7 \mathrm{E}-13$ & $1.0 \mathrm{E}-3$ & 0.13 & $2.3 \mathrm{E}-3$ & 0.633 & 0.46 \\
\hline
\end{tabular}

Output DTN: LB0207REVUZPRP.001.

$\mathrm{CFu}=$ Crater Flat undifferentiated hydrogeologic unit; $\mathrm{CHn}=$ Calico Hills nonwelded hydrogeologic unit; PTn=Paintbrush nonwelded hydrogeologic unit; TCw=Tiva Canyon welded hydrogeologic unit;

TSw=Topopah Spring welded hydrogeologic unit

\subsection{UNCERTAINTIES, ALTERNATIVE APPROACHES, AND OTHER ISSUES}

Uncertainties of most of these properties are reported using the corresponding standard deviations or standard errors (e.g., Tables 6-4 to 6-6) while some properties are subject to additional uncertainties due to lack of measured data in certain rock units. Alternative values from different sources have been used to verify the estimated properties (Section 6.1.3.4), and alternative approaches have been used to provide alternative parameter set (Section 6.2.4). As indicated in Section 1, these properties are uncalibrated and intended to serve only as initial estimates for the Calibrated Properties Model (BSC 2004 [DIRS 169857]). 


\section{CONCLUSIONS}

\subsection{SUMMARY}

Methodologies have been described for providing representative estimates of fracture and matrix properties for UZ Model layers, based on the relevant data. The fracture and matrix properties developed here were submitted to the TDMS under Output DTNs: LB0205REVUZPRP.001 and LB0207REVUZPRP.002, respectively. The supporting data files for developing the fracture properties were submitted to the TEMS under Output DTN: LB0408REVUZPRP.001. Fault properties developed here were submitted to the TDMS under Output DTN: LB0207REVUZPRP.001. Estimated properties are documented in this report for use as prior information for the inversion processes within a model report, Calibrated Properties Model (BSC 2004 [DIRS 169857]). The resultant fracture geometry properties are important inputs for the development of the UZ Model grids. The independent determination of fracture properties, based on ESF seepage test results, confirms the appropriateness of the estimated fracture properties and the procedures used for the estimation.

Like many field-scale problems, data availability and limitations in approaches for upscaling flow parameters directly from small-scale measurements are major sources of uncertainties in the estimated hydraulic properties. It is particularly true for the unsaturated fractured rocks, due to the complexity of the flow processes involved. To reduce the uncertainties, model calibrations are generally needed. Therefore, it should be emphasized that flow parameter estimates reported herein are only developed as inputs into model calibrations, and should not be directly used for modeling UZ flow and transport processes without careful evaluation.

Output DTNs from this report are LB0205REVUZPRP.001, LB0207REVUZPRP.001, LB0207REVUZPRP.002, and LB0408REVUZPRP.001. Calibration is discussed in a separate model report describing the Calibrated Properties Model (BSC 2004 [DIRS 169857].

\subsection{HOW THE APPLICABLE ACCEPTANCE CRITERIA ARE ADDRESSED}

The following information describes how this analysis addresses the hydrologic aspects of the following acceptance criteria in the Yucca Mountain Review Plan (NRC 2003 [DIRS 163274], Section 2.2.1.3.6.3). As stated in Section 4.2, only those acceptance criteria that are applicable to this report are discussed. In most cases, the applicable acceptance criteria are not addressed solely by this report; rather, the acceptance criteria are fully addressed when this report is considered in conjunction with other analysis and model reports that describe flow in the unsaturated zone. Where a subcriterion includes several components, only some of those components may be addressed. How these components are addressed is summarized below.

\section{Acceptance Criteria from Section 2.2.1.3.6.3, Flow Paths in the Unsaturated Zone}

Acceptance Criterion 1: System Description and Model Integration Are Adequate.

Subcriterion (1): Important physical phenomena (i.e., the special flow patterns caused by existing of fractures and faults) relating to UZ flow are incorporated by the generation of fracture properties (Section 6.1), matrix properties (Section 6.2), and fault properties (Section 6.3) provided in this report. This information feeds into the calibrated properties model that provides the input for process models and TSPA simulations. 
Subcriterion (2): The data synthesized in Sections 6.1, 6.2, and 6.3 of this report adequately describe properties of the UZ that affect flow in the fractures and matrix of the unsaturated zone. Fracture properties are based upon air-injection tests, gas tracer tests, borehole data, and a survey of fracture data (Section 6.1). Matrix properties are based upon laboratory measurements on core samples (Section 6.2). Fracture permeability for faults are based on air-injection tests and other fracture properties are based on averages of properties of the corresponding non-fault layer (Section 6.3). These values are averaged for each hydrologic unit (for the major HGUs in the case of the faults). These properties are uncalibrated and serve only as initial estimates in the calibrated properties model that provides the input for the process model and TSPA simulations. The inverse modeling helps to ensure that the calibrated values for each hydrologic unit are appropriate for the UZ model.

Subcriterion (3): Technical bases and data (e.g., separation of fracture-flow and matrix flow) employed in this analysis are appropriate and consistently applied in developing related abstractions. In particular, information about fracture and matrix properties from this analysis feeds into the calibrated properties model that provides the input for TSPA simulations.

Subcriterion (7): As shown in Section 6, Table 6-1, the hydrologic units used in this report for calculating the average parameters (in this case, parameters related to spatial discretizations in the UZ) are consistent with those used in the site-scale flow model.

Subcriterion (9): This report was developed in accordance with the Quality Assurance Requirements and Description (QARD) (DOE 2004 [DIRS 171539]), which commits to NUREG-1297 (Altman et al. 1988 [DIRS 103597]) and NUREG-1298 (Altman et al. 1988 [DIRS 103750]). Moreover, compliance with the DOE procedures, which are designed to ensure compliance with the QARD (DOE 2004 [DIRS 171539]), is verified by audits by QA and other oversight activities. Accordingly, the guidance in NUREG-1297 (Altman et al. 1988 [DIRS 103597]) and NUREG-1298 (Altman et al. 1988 [DIRS 103750]) has been followed as appropriate.

\section{Acceptance Criterion 2: Data Are Sufficient for Model Justification.}

Subcriterion (1): Sections 6.1 through 6.3 of this report provide adequate descriptions of the scientific basis and the methodologies (e.g., air-injection tests and gas-tracer tests) for appropriate synthesis of measured data into hydrological parameters.

Subcriterion (2): The quality of the data used in this report is assured by the QA program (Section 2). Approved QA procedures identified in the TWP (BSC 2004 [DIRS 169654], Section 4) have been used to conduct and document the activities described in this analysis report.

\section{Acceptance Criterion 3: Data Uncertainty is Characterized and Propagated Through the Model Abstraction.}

Subcriterion (6): Uncertainties of most of the hydrologic properties are reported using the corresponding standard deviations or standard errors (e.g., Tables 6-4 to 6-6). Alternative values from seven different sources were used to verify the estimated fracture porosities (Section 6.1.3.4). 


\section{INPUTS AND REFERENCES}

\subsection{DOCUMENTS CITED}

Ahlers, R. 2000. Unsaturated Zone Modeling \& Synthesis. Scientific Notebook

155853

YMP-LBNL-GSB-1.1.2. ACC: MOL.20000726.0157.

Altman, W.D.; Donnelly, J.P.; and Kennedy, J.E. 1988. Peer Review for High-Level

103597

Nuclear Waste Repositories: Generic Technical Position. NUREG-1297.

Washington, D.C.: U.S. Nuclear Regulatory Commission. TIC: 200651.

Altman, W.D.; Donnelly, J.P.; and Kennedy, J.E. 1988. Qualification of Existing

103750

Data for High-Level Nuclear Waste Repositories: Generic Technical Position.

NUREG-1298. Washington, D.C.: U.S. Nuclear Regulatory Commission.

TIC: 200652.

Bear, J.; Tsang, C.F.; and de Marsily, G., eds. 1993. . Flows and Contaminant

116773

Transport in Fractured Rock. San Diego, California: Academic Press.

TIC: 235461.

BSC (Bechtel SAIC Company) 2001. Analysis of Hydrologic Properties Data. ANL-NBS-HS-000002 REV 00 ICN 01. Las Vegas, Nevada: Bechtel SAIC Company. ACC: MOL.20020429.0296.

BSC 2003. Analysis of Hydrologic Properties Data. MDL-NBS-HS-000014 REV

161773 00. Las Vegas, Nevada: Bechtel SAIC Company. ACC: DOC.20030908.0001.

BSC 2004. Calibrated Properties Model. MDL-NBS-HS-000003, Rev. 02. Las 169857 Vegas, Nevada: Bechtel SAIC Company.

BSC 2004. Conceptual Model and Numerical Approaches for Unsaturated Zone

170035 Flow and Transport. MDL-NBS-HS-000005 REV 01. Las Vegas, Nevada: Bechtel SAIC Company.

BSC 2004. Development of Numerical Grids for UZ Flow and Transport Modeling. ANL-NBS-HS-000015, Rev. 02. Las Vegas, Nevada: Bechtel SAIC Company.

BSC 2004. Geologic Framework Model (GFM2000). MDL-NBS-GS-000002 REV 02. Las Vegas, Nevada: Bechtel SAIC Company. ACC: MOL.20040827.0008.

BSC 2004. In Situ Field Testing of Processes. ANL-NBS-HS-000005, Rev. 03. Las Vegas, Nevada: Bechtel SAIC Company.

BSC 2004. Q-List. 000-30R-MGR0-00500-000-000 REV 00. Las Vegas, Nevada: Bechtel SAIC Company. ACC: ENG.20040721.0007. 
BSC 2004. Seepage Calibration Model and Seepage Testing Data. MDL-NBS-HS- 171764 000004 REV 03. Las Vegas, Nevada: Bechtel SAIC Company.

ACC: DOC.20040922.0003.

BSC 2004. Technical Work Plan for: Unsaturated Zone Flow Analysis and Model

169654

Report Integration. TWP-MGR-HS-000001 REV 00. Las Vegas, Nevada: Bechtel SAIC Company. ACC: DOC.20040701.0005.

BSC 2004. Thermal Conductivity of the Potential Repository Horizon. MDL-NBSGS-000005, Rev. 01. Las Vegas, Nevada: Bechtel SAIC Company.

Canori, G.F. and Leitner, M.M. 2003. Project Requirements Document.

166275

TER-MGR-MD-000001 REV 02. Las Vegas, Nevada: Bechtel SAIC Company.

ACC: DOC.20031222.0006.

CRWMS (Civilian Radioactive Waste Management System) M\&O (Management \& 102679 Operating Contractor) 1998. Geology of the Exploratory Studies Facility Topopah Spring Loop. BAB000000-01717-0200-00002 REV 01. Las Vegas, Nevada:

CRWMS M\&O. ACC: MOL.19980415.0283.

DOE (U.S. Department of Energy) 2004. Quality Assurance Requirements and Description. DOE/RW-0333P, Rev. 16. Washington, D.C.: U.S. Department of Energy, Office of Civilian Radioactive Waste Management.

ACC: DOC.20040907.0002.

Domenico, P.A. and Schwartz, F.W. 1990. Physical and Chemical Hydrogeology.

100569 New York, New York: John Wiley \& Sons. TIC: 234782.

Flint, L.E. 1998. Characterization of Hydrogeologic Units Using Matrix Properties, 100033 Yucca Mountain, Nevada. Water-Resources Investigations Report 97-4243. Denver, Colorado: U.S. Geological Survey. ACC: MOL.19980429.0512.

Freifeld, B.M. 2001. Estimation of Fracture Porosity in an Unsaturated Fractured Welded Tuff Using Gas Tracer Testing. Ph.D. thesis. Berkeley, California: University of California, Berkeley, Department of Civil and Environmental Engineering. TIC: 253904.

Gelhar, L.W. 1993. Stochastic Subsurface Hydrology. Englewood Cliffs, New Jersey: Prentice-Hall. TIC: 240652.

Hvorslev, M.J. 1951. Time Lags and Soil Permeability in Ground-Water Observations. AEWES Bulletin 36. Vicksburg, Mississippi: U.S. Army Corps of Engineers, Waterways Experiment Station. TIC: 238956. 
Kazemi, H. and Gilman, J.R. 1993. "Multiphase Flow in Fractured Petroleum

Reservoirs."' Chapter 6 of Flow and Contaminant Transport in Fractured Rock. Bear, J.; Tsang, C-F.; and de Marsily, G., eds. San Diego, California: Academic Press. TIC: 235461.

LeCain, G.D. 1995. Pneumatic Testing in 45-Degree-Inclined Boreholes in Ash-

101700

Flow Tuff Near Superior, Arizona. Water-Resources Investigations Report 95-4073.

Denver, Colorado: U.S. Geological Survey. ACC: MOL.19960715.0083.

LeCain, G.D. 1998. Results from Air-Injection and Tracer Testing in the Upper Tiva

100052

Canyon, Bow Ridge Fault, and Upper Paintbrush Contact Alcoves of the Exploratory

Studies Facility, August 1994 through July 1996, Yucca Mountain, Nevada.

Water-Resources Investigations Report 98-4058. Denver, Colorado:

U.S. Geological Survey. ACC: MOL.19980625.0344.

LeCain, G.D.; Anna, L.O.; and Fahy, M.F. 2000. Results from Geothermal Logging,

144612 Air and Core-Water Chemistry Sampling, Air-Injection Testing, and Tracer Testing in the Northern Ghost Dance Fault, Yucca Mountain, Nevada, November 1996 to August 1998. Water-Resources Investigations Report 99-4210. Denver, Colorado: U.S. Geological Survey. TIC: 247708.

Lide, D.R., ed. 2002. CRC Handbook of Chemistry and Physics. 83rd Edition. Boca Raton, Florida: CRC Press. TIC: 253582.

Lin, M.; Hardy, M.P.; and Bauer, S.J. 1993. Fracture Analysis and Rock Quality Designation Estimation for the Yucca Mountain Site Characterization Project. SAND92-0449. Albuquerque, New Mexico: Sandia National Laboratories. ACC: NNA.19921204.0012.

Liu, H-H.; Haukwa, C.B.; Ahlers, C.F.; Bodvarsson, G.S.; Flint, A.L.; and Guertal, W.B. 2003. "Modeling Flow and Transport in Unsaturated Fractured Rock: An Evaluation of the Continuum Approach." Journal of Contaminant Hydrology, 62-63, 173-188. New York, New York: Elsevier. TIC: 254205.

Millington, R.J. and Quirk, J.M. 1961. "Permeability of Porous Solids." 139143 Transactions of the Faraday Society, 57, (7), 1200-1207. Toronto, Canada: Royal Society of Chemistry. TIC: 246707.

Moench, A.F. 1989. "Convergent Radial Dispersion: A Laplace Transform Solution for Aquifer Tracer Testing." "Water Resources Research, 25, (3), 439-447. Washington, D.C.: American Geophysical Union. TIC: 238283.

Montazer, P. and Wilson, W.E. 1984. Conceptual Hydrologic Model of Flow in the Unsaturated Zone, Yucca Mountain, Nevada. Water-Resources Investigations Report 84-4345. Lakewood, Colorado: U.S. Geological Survey.

ACC: NNA.19890327.0051. 
National Research Council. 1996. Rock Fractures and Fluid Flow, Contemporary

Understanding and Applications. Washington, D.C.: National Academy Press.

TIC: 235913.

Neuman, S.P.; Illman, W.A.; Vesselinov, V.V.; Thompson, D.L.; Chen, G.; and

160849 Guzman, A. 2001. "Lessons from Field Studies at the Apache Leap Research Site in Arizona." Chapter 10 of Conceptual Models of Flow and Transport in the Fractured Vadose Zone. Washington, D.C.: National Academy Press. TIC: 252777.

NRC (U.S. Nuclear Regulatory Commission) 2003. Yucca Mountain Review Plan, Final Report. NUREG-1804, Rev. 2. Washington, D.C.: U.S. Nuclear Regulatory Commission, Office of Nuclear Material Safety and Safeguards. TIC: 254568.

Paleologos, E.K.; Neuman, S.P.; and Tartakovsky, D. 1996. "Effective Hydraulic Conductivity of Bounded, Strongly Heterogeneous Porous Media."' Water Resources Research, 32, (5), 1333-1341. Washington, D.C.: American Geophysical Union. TIC: 245760.

Pruess, K. 1987. TOUGH User's Guide. NUREG/CR-4645. Washington, D.C.: 100684 U.S. Nuclear Regulatory Commission. TIC: 217275.

Pruess, K. and Tsang, Y.W. 1990. “On Two-Phase Relative Permeability and 170866 Capillary Pressure of Rough-Walled Rock Fractures."' Water Resources Research, 26, (9), 1915-1926. Washington, D.C.: American Geophysical Union.

TIC: 224853.

Renard, Ph. and de Marsily, G. 1997. "Calculating Equivalent Permeability: A 170240 Review."' Advances in Water Resources, 20, (5-6), 253-278. New York, New York: Elsevier. TIC: 256209.

Rousseau, J.P.; Kwicklis, E.M.; and Gillies, D.C., eds. 1999. Hydrogeology of the 102097 Unsaturated Zone, North Ramp Area of the Exploratory Studies Facility, Yucca Mountain, Nevada. Water-Resources Investigations Report 98-4050. Denver, Colorado: U.S. Geological Survey. ACC: MOL.19990419.0335.

Schaap, M.G. and Leij, F.J. 2000. "Improved Prediction of Unsaturated Hydraulic Conductivity with the Mualem-van Genuchten Model."' Soil Science Society of America Journal, 64, (3), 843-851. Madison, Wisconsin: Soil Science Society of America. TIC: 253607.

Starr, R.C.; Gillham, R.W.; and Sudicky, E.A. 1985. "Experimental Investigation of 101479 Solute Transport in Stratified Porous Media, 2. The Reactive Case." Water Resources Research, 21, (7), 1043-1050. Washington, D.C.: American Geophysical Union. TIC: 222358. 
van Genuchten, M.T. 1980. "A Closed-Form Equation for Predicting the Hydraulic

100610 Conductivity of Unsaturated Soils."' Soil Science Society of America Journal, 44,

(5), 892-898. Madison, Wisconsin: Soil Science Society of America. TIC: 217327.

Wang, J.S. 2003. "Scientific Notebooks Referenced in Model Report U0090,

161654 Analysis of Hydrologic Properties Data, MDL-NBS-HS-000014 REV 00” Interoffice correspondence from J.S. Wang (BSC) to File, February 28, 2003, with attachments. ACC: MOL.20030306.0535.

Wang, J.S.Y. and Narasimhan, T.N. 1993. "Unsaturated Flow in Fractured Porous Media."' Chapter 7 of Flow and Contaminant Transport in Fractured Rock. Bear, J.; Tsang, C-F.; and de Marsily, G., eds. San Diego, California: Academic Press. TIC: 235461 .

Wen, X-H. and Gómez-Hernández, J.J. 1996. "Upscaling Hydraulic Conductivities 170239 in Heterogeneous Media: An Overview."' Journal of Hydrology, 183, (1-2), ix-xxxii. New York, New York: Elsevier. TIC: 256208.

Wu, Y-S.; Pan, L.; Zhang, W.; and Bodvarsson, G.S. 2002. "Characterization of Flow and Transport Processes within the Unsaturated Zone of Yucca Mountain, Nevada, Under Current and Future Climates."' Journal of Contaminant Hydrology, 54, (3-4), 215-247. New York, New York: Elsevier. TIC: 253316.

Zhou, Q.; Liu, H-H.; Bodvarsson, G.S.; and Oldenburg, C.M. 2003. "Flow and Transport in Unsaturated Fractured Rock: Effects of Multiscale Heterogeneity of Hydrogeologic Properties."' Journal of Contaminant Hydrology, 60, (1-2), 1-30. New York, New York: Elsevier. TIC: 253978.

\subsection{CODES, STANDARDS, REGULATIONS, AND PROCEDURES}

15660510 CFR 63. Energy: Disposal of High-Level Radioactive Wastes in a Geologic Repository at Yucca Mountain, Nevada.

AP-2.22Q, Rev. 1, ICN 1. Classification Analyses and Maintenance of the Q-List. Washington, D.C.: U.S. Department of Energy, Office of Civilian Radioactive Waste Management.

ACC: DOC.20040714.0002.

AP-3.15Q, Rev. 4, ICN 5. Managing Technical Product Inputs. Washington, D.C.: U.S. Department of Energy, Office of Civilian Radioactive Waste Management.

ACC: DOC.20040812.0004.

LP-SI.11Q-BSC, Rev. 0, ICN0. Software Management. Washington, D.C.: U.S. Department of Energy, Office of Civilian Radioactive Waste Management. ACC:DOC.20040225.0007.

AP-SIII.9Q, REV.1, ICN 7. Scientific Analyses. Washington, D.C.: U.S. Department of Energy, Office of Civilian Radioactive Waste Management. ACC: DOC.20040920.0001. 


\subsection{SOURCE DATA, LISTED BY DATA TRACKING NUMBER}

GS000608314211.003. Stratigraphic Contact for 26 Yucca Mountain Boreholes.

161658

Submittal date: 04/09/2001.

GS010608312242.001. Unsaturated Hydraulic Conductivity and Matric Potential in

160822

Busted Butte Volcanic Tuff Cores. Submittal date: 08/07/2001.

GS940208314211.007. Table of Contacts in Borehole USW UZ-N35.

155533

Submittal date: 02/10/1994.

GS940208314211.008. Table of Contacts in Boreholes USW UZ-N57, UZ-N58,

145581

UZ-N59, and UZ-N61. Submittal date: 02/10/1994.

GS940308314211.018. Table of Contacts for the Tiva Canyon Tuff in Borehole USW UZ-N36. Submittal date: 03/28/1994.

GS950108314211.008. Lithostratigraphic Data for Paintbrush Group Bedded Tuff Units TPBT3 and TPBT4 in Boreholes USW UZ-N11, USW UZ-14, USW NRG7/7A, USW SD-9, USW UZ-N37, USW NRG-6, UE-25 NRG\#2B, USW UZ-N31, USW UZ-N32, USW SD-12, UE-25 UZ\#16, USW UZ-N54, USW UZ-N53.

Submittal date: 01/20/1995.

GS950108314211.009. Stratigraphic Descriptions and Data for the Yucca Mountain

152556 Tuff in Boreholes NRG\#2B, NRG-7/7A, SD-9, UZ-14, UZ\#16, UZ-N11, UZ-N33, UZ-N34, UZ-N53, UZ-N54, UZ-N55. Submittal date: 01/27/1995.

GS950608312231.008. Moisture Retention Data from Boreholes USW UZ-N27 and UE-25 UZ\#16. Submittal date: 06/06/1995.

GS950708314211.028. Stratigraphic Descriptions of the Pah Canyon Tuff in Boreholes UE-25 NRG \#2B, UE-25 NRG\#4, USW NRG-6, USW NRG-7/7A, USW SD-9, USW SD-12, USW UZ-14, USW UZ-N31, USW UZ-N32, AND USW UZ-N37. Submittal date: 07/20/1995.

GS960708314224.008. Provisional Results: Geotechnical Data for Station $30+00$ to Station 35 + 00, Main Drift of the ESF. Submittal date: 08/05/1996.

GS960708314224.010. Provisional Results: Geotechnical Data for Station 40+00 to Station 45+00, Main Drift of the ESF. Submittal date: 08/05/1996.

GS960808312231.003. Moisture Retention Data for Samples from Boreholes 147590 USW SD-7, USW SD-9, USW SD-12 and UE-25 UZ\#16. Submittal date: 08/30/1996.

GS960808314224.011. Provisional Results: Geotechnical Data for Station 35+00 to 106029 Station 40+00, Main Drift of the ESF. Submittal date: 08/29/1996. 
GS960908312232.013. Air-Injection Testing in Vertical Boreholes in Welded and

105574

Non-Welded Tuff, Yucca Mountain, Nevada. Submittal date: 09/26/1996.

GS960908314224.014. Provisional Results - ESF Main Drift, Station 50+00 to

106033

Station 55+00. Submittal date: 09/09/1996.

GS960908314224.018. Provisional Results: Geotechnical Data for Alcove 5

106067

(DWFA), Main Drift of the ESF. Submittal date: 09/09/1996.

GS960908314224.020. Analysis Report: Geology of the North Ramp - Stations 4+00

106059

to 28+00 and Data: Detailed Line Survey and Full-Periphery Geotechnical Map -

Alcoves 3 (UPCA) and 4 (LPCA), and Comparative Geologic Cross Section -

Stations 0+60 to 28+00. Submittal date: 09/09/1996.

GS970183122410.001. Results from Air-Injection and Tracer Testing in the Upper

105580

Tiva Canyon, Bow Ridge Fault, and Upper Paintbrush Contact Alcoves of the

Exploratory Studies Facility, August 1994 through July 1996, Yucca Mountain,

Nevada. Submittal date: 02/03/1997.

GS970308314222.001. Fracture Data from Natural Outcrops of the Calico Hills

106075

Formation and the Topopah Spring Tuff at 10 Locations in the Vicinity of Prow Pass, at the Head of Yucca Wash, North of Yucca MTN, and 2 Locations at the NE End of Busted Butte, SE of Yucca MTN. Submittal date: 03/26/1997.

GS970808314224.008. Provisional Results: Geotechnical Data for Station 65+00 to Station 70+00, South Ramp of the ESF. Submittal date: 08/18/1997.

GS970808314224.010. Provisional Results: Geotechnical Data for Station 70+00 to Station 75+00, South Ramp of the ESF. Submittal date: 08/25/1997.

GS970808314224.012. Provisional Results: Geotechnical Data for Station $75+00$ to Station 78+77, South Ramp of the ESF. Submittal date: 08/25/1997.

GS970808314224.014. Provisional Results: Geotechnical Data for Alcove 6 and 106069 Alcove 6 Drill Alcove, Main Drift of the ESF. Submittal date: 08/25/1997.

GS971008312231.006. Physical Properties and Saturated Hydraulic Conductivity of 107184 Cores from Surface Samples from the ESF Main Drift 29+00 M to 57+00 M. Submittal date: 10/06/1997.

GS971108314224.020. Revision 1 of Detailed Line Survey Data, Station 0+60 to 105561 Station 4+00, North Ramp Starter Tunnel, Exploratory Studies Facility.

Submittal date: 12/03/1997.

GS971108314224.021. Revision 1 of Detailed Line Survey Data, Station 4+00 to 106007 Station 8+00, North Ramp, Exploratory Studies Facility. Submittal date: 12/03/1997. 
GS971108314224.022. Revision 1 of Detailed Line Survey Data, Station 8+00 to

106009

Station 10+00, North Ramp, Exploratory Studies Facility.

Submittal date: 12/03/1997.

GS971108314224.023. Revision 1 of Detailed Line Survey Data, Station $10+00$ to

106010

Station $18+00$, North Ramp, Exploratory Studies Facility.

Submittal date: $12 / 03 / 1997$.

GS971108314224.024. Revision 1 of Detailed Line Survey Data, Station $18+00$ to

106023

Station 26+00, North Ramp, Exploratory Studies Facility.

Submittal date: $12 / 03 / 1997$.

GS971108314224.025. Revision 1 of Detailed Line Survey Data, Station 26+00 to

106025

Station 30+00, North Ramp and Main Drift, Exploratory Studies Facility.

Submittal date: 12/03/1997.

GS971108314224.026. Revision 1 of Detailed Line Survey Data, Station 45+00 to

106032

Station 50+00, Main Drift, Exploratory Studies Facility. Submittal date: 12/03/1997.

GS971108314224.028. Revision 1 of Detailed Line Survey Data, Station 55+00 to

106047

Station 60+00, Main Drift and South Ramp, Exploratory Studies Facility.

Submittal date: $12 / 03 / 1997$.

GS980308312242.005. Physical Properties of Lexan-Sealed Borehole Samples from the PTN Exposure in the ESF North Ramp (ESF Station 7+27 M to ESF Station 10+70 M). Submittal date: 03/11/1998.

GS980408312242.008. Unsaturated Hydraulic Properties of Borehole Samples from 107161 the PTN Exposure in the ESF North Ramp (ESF Station 7+27 M to ESF Station 10+70 M) Measured Using a Centrifuge. Submittal date: 04/17/1998.

GS980708312242.010. Physical Properties of Borehole Core Samples, and Water 106752 Potential Measurements Using the Filter Paper Technique, for Borehole Samples from USW WT-24. Submittal date: 07/27/1998.

GS980708312242.011. Physical Properties and Hydraulic Conductivity

107150

Measurements of Lexan-Sealed Samples from USW WT-24.

Submittal date: 07/30/1998.

GS980808312242.012. Unsaturated Hydraulic Properties of Lexan-Sealed Samples From USW WT-24, Measured Using a Centrifuge. Submittal date: 08/05/1998.

149375

GS980808312242.014. Physical Properties of Borehole Core Samples and Water 106748 Potential Measurements Using the Filter Paper Technique for Borehole Samples from USW SD-6. Submittal date: 08/11/1998. 
GS980908312242.037. Water Retention Data of Lexan-Sealed Borehole Samples

107180 and Surface Samples from ESF North Ramp Moisture Study.

Submittal date: 09/23/1998.

GS980908312242.038. Physical Properties and Saturated Hydraulic Conductivity

107154

Measurements of Lexan-Sealed Samples from USW SD-6.

Submittal date: 09/22/1998.

GS980908312242.039. Unsaturated Water Retention Data for Lexan-Sealed

145272

Samples from USW SD-6 Measured Using a Centrifuge. Submittal date: 09/22/1998.

GS980908312242.040. Physical Properties and Saturated Hydraulic Conductivity

107169

Measurements of Core Plugs from Lexan-Sealed Samples from Boreholes in the ESF

North Ramp. Submittal date: 09/24/1998.

GS980908312242.041. Physical Properties and Saturated Hydraulic Conductivity

Measurements of Core Plugs from Boreholes USW SD-7, USW SD-9, USW SD-12, USW UZ-14, and UE-25 UZ\#16. Submittal date: 09/24/1998.

GS981108314224.005. Locations of Lithostratigraphic Contacts in the ECRB Cross Drift. Submittal date: 11/30/1998.

GS990308312242.007. Laboratory and Centrifuge Measurements of Physical and Hydraulic Properties of Core Samples from Busted Butte Boreholes UZTT-BB-INJ1, UZTT-BB-INJ-3, UZTT-BB-INJ-4, UZTT-BB-INJ-6, UZTT-BB-COL-5 and UZTT-BB-COL-8. Submittal date: 03/22/1999.

GS990408314224.001. Detailed Line Survey Data for Stations 00+00.89 to

108396

14+95.18, ECRB Cross Drift. Submittal date: 09/09/1999.

GS990408314224.002. Detailed Line Survey Data for Stations $15+00.85$ to 26+63.85, ECRB Cross Drift. Submittal date: 09/09/1999.

105625

GS990708312242.008. Physical and Hydraulic Properties of Core Samples from

109822

Busted Butte Boreholes. Submittal date: 07/01/1999.

GS990883122410.002. Qualified Data in "Results from Geothermal Logging, Air 135230 and Core-Water Chemistry Sampling, Air-Injection Testing and Tracer Testing in the Northern Ghost Dance Fault, November, 1996 - August, 1998”.

Submittal date: 08/16/1999.

LA0207SL831372.001. Lithostratigraphic Classification of Hydrologic-Property 160824 Core-Sampling Depths, Busted Butte Phase 2 Test Block.

Submittal date: 07/16/2002.

LAJF831222AQ98.014. Chloride, Bromide, and Sulfate Analyses of Salts Leached from ESF-NR-Moiststdy Drillcore. Submittal date: 09/09/1998.

160825 
LB0110LIQR0015.001. Developed Data for Liquid Release/Seepage Tests and Systematic Testing. Submittal date: 11/12/2001.

LB960500834244.001. Hydrological Characterization of the Single Heater Test Area 105587 in ESF. Submittal date: 08/23/1996.

LB970600123142.001. Ambient Characterization of the ESF Drift Scale Test Area

105589 by Field Air Permeability Measurements. Submittal date: 06/13/1997.

LB980120123142.004. Air Injections in Boreholes 57 through 61, 74 through 78, 185 and 186 in the Drift Scale Test Area. Submittal date: 01/20/1998.

LB980120123142.005. Hydrological Characterization by Air Injections Tests in

114134 Boreholes in Heated Drift in DST. Submittal date: 01/20/1998.

LB980901233124.003. Liquid Release and Tracer Tests in Niches 3566, 3650, 3107, and 4788 in the ESF. Submittal date: 09/14/1998.

LB980912332245.002. Gas Tracer Data from Niche 3107 of the ESF. Submittal date: 09/30/1998.

105593

LB990501233129.001. Fracture Properties for the UZ Model Grids and Uncalibrated 106787 Fracture and Matrix Properties for the UZ Model Layers for AMR U0090, "Analysis of Hydrologic Properties Data". Submittal date: 08/25/1999.

LB990901233124.004. Air Permeability Cross-Hole Connectivity in Alcove 6, Alcove 4, and Niche 4 of the ESF for AMR U0015, "In Situ Testing of Field Processes". Submittal date: 11/01/1999.

MO0012MWDGFM02.002. Geologic Framework Model (GFM2000).

153777

Submittal date: $12 / 18 / 2000$.

MO0109HYMXPROP.001. Matrix Hydrologic Properties Data.

155989

Submittal date: 09/17/2001.

MO0407SEPFEPLA.000. LA FEP List. Submittal date: 07/20/2004.

170760

TM000000SD12RS.012. USW SD-12 Composite Borehole Log (0.0'-1435.3') and 105627 Weight Logs (1,438.8-2,151.7'). Submittal date: 09/08/1995.

TM000000UZ7ARS.001. USW UZ-7A Shift Drilling Summaries, Lithologic Logs, 160826 Structural Logs, Weight Logs, and Composite Borehole Log from 0.0' to 770.0'. Submittal date: 09/05/1995. 


\subsection{OUTPUT DATA, LISTED BY DATA TRACKING NUMBER}

LB0205REVUZPRP.001. Fracture Properties for UZ Model Layers Developed from Field Data. Submittal date: 05/14/2002.

LB0207REVUZPRP.001. Revised UZ Fault Zone Fracture Properties. Submittal date: 07/03/2002.

LB0207REVUZPRP.002. Matrix Properties for UZ Model Layers Developed from Field and Laboratory Data. Submittal date: 07/15/2002.

LB0408REVUXPRP.001. Pre-Processing - Fracture Properties for UZ Model Layers Developed from Field Data. Submittal date: 08/26/2004.

\subsection{SOFTWARE CODES}

N/A 


\section{INTENTIONALLY LEFT BLANK}


APPENDIX A

DESCRIPTION OF EXCEL FILES USED 
This appendix describes Excel files used for developing uncalibrated hydraulic properties. The data mentioned in this appendix were downloaded directly from TDMS unless otherwise noted. The Excel files were also submitted to TDMS. The relationships between the output DTNs of this report and the Excel files described in Appendix A are as follows:

LB0207REVUZPRP.002 (matrix properties): hydroprops_fin.xls, MRC_Q_TCw_fin.xls, MRC_Q_PTn_fin.xls MRC_Q_TSW_FIN.XLS, $M R C Q C H C F$ FIN.XLS, and $v G \_$Summary_fin.xls

LB0408REVUZPRP.001 (fracture properties): lecan97.xls, UTCA_BRFA.xls, drift.xls, airk.xls, and Fpor.xls

\section{hydroprops_fin.xls (Output DTN: LB0207REVUZPRP.002)}

This file was used to develop matrix properties for UZ model layers.

Worksheet 'borehole data'

- Import DTN: MO0109HYMXPROP.001 [DIRS 155989]

- Import DTN: GS980708312242.010 [DIRS 106752] (WT-24 physical properties, corresponding to data files with names staring with "zz-sep" in the same DTN), and GS980808312242.014 [DIRS 106748] (SD-6 physical properties, corresponding to data files with names staring with "zz-sep" in the same DTN) into same columns used in MO0109HYMXPROP.001 [DIRS 155989]

- Import DTNs: GS980708312242.011 [DIRS 107150] (WT-24 high pressure permeameter conductivity), GS980908312242.038 [DIRS 107154] (SD-6 high pressure permeameter conductivity), and GS980908312242.041 [DIRS 107158] (SD-7, SD-9, SD-12, UZ-14, and UZ\#16 high pressure permeameter conductivity) into columns AA to AD

- Added column D, depth in $\mathrm{ft}$, converted from column $\mathrm{F}$

- Added column J, residual water content (RWC), with conditional formatting to highlight residual water content $\geq 5$ percent

- Calculated saturation, in column N, for WT-24 and SD-6

- Added GFM lithostratigraphy from DTN: MO0012MWDGFM02.002 [DIRS 153777] file contacts00md.dat to columns $\mathrm{S} \& \mathrm{~T}$. Where contacts00md.dat did not have borehole, note in column U indicates source of lithostratigraphy (DTNs also listed in rows 5389-5398:

GS950108314211.009 [DIRS 152556], GS940208314211.007 [DIRS 155533], GS940308314211.018 [DIRS 145589], GS950108314211.008 [DIRS 152558], GS950708314211.028 [DIRS 160827], GS940208314211.008 [DIRS 145581], TM000000UZ7ARS.001 [DIRS 160826]) 
Hydrostratigraphy (hydrogeologic unit - HGU) is determined in column V (based on rules of Flint (1998 [DIRS 100033], pp. 21-32); groupings indicated below are for UZ Model layers:

- $1 \& 2=\mathrm{CCR} \& \mathrm{CUC} \approx \mathrm{Tpcrn} \& \mathrm{Tpcrl}$, lower contact (1.c.) of CCR where porosity $(\phi)$ $>9$ percent, 1.c. of CUC where $\phi<20$ percent. Units are combined because greater property resolution is not needed at upper margin of UZ Model

- $3 \& 4=$ CUL \& CW $\approx$ Tpcpul \& Tpcpmn \& Tpcpll \& Tpcpln, 1.c. of CUL at lithostratigraphic contact (1.c. of Tpcpul of identified in columns P \& Q, but contact is unimportant for UZ Model hydrostratigraphy), l.c. of CW where $\phi>15$ percent. Units are combined because greater property resolution is not needed at upper margin of UZ Model

- $5=\mathrm{CMW} \approx$ base of Tpcpln \& Tpcpv3 \& Tpcpv2, 1.c. where $\phi>28$ percent

- $6=\mathrm{CNW} \approx$ base of Tpcpv2 \& Tpcpv1, 1.c. at lithostratigraphic contact (1.c. of Tpcpv1)

- $7=$ BT4 $\approx$ Tpbt4 \& top of Tpy, 1.c. where $\phi>30$ percent or at 1.c. of Tpy whichever is stratigraphically higher

- $8=$ TPY $\approx$ moderately welded interior of Tpy, 1.c. where $\phi<30$ percent

- $9=$ BT3 $\approx$ base of Tpy \& Tpbt3, 1.c. at lithostratigraphic contact (1.c. of Tpbt3) (note: if Tpbt4 is not present and Tpy $\phi>30$ percent then all Tpy is included in BT3)

- $10=\mathrm{TPP}=\mathrm{Tpp}$

- $11=\mathrm{BT} 2 \approx$ Tpbt2 \& Tptrv3 \& Tptrv2, 1.c. at lithostratigraphic contact (1.c. of Tptrv2)

- $12=\mathrm{TC} \approx \mathrm{Tptrv} 1 \&$ top of Tptrn, 1.c. where $\phi>9$ percent

- $13=\mathrm{TR} \approx \mathrm{T}$ trn, 1.c. at lithostratigraphic contact (1.c. of Tptrn)

- $14=\mathrm{TUL}=\mathrm{Tptrl} \&$ Tptpul

- $15=\mathrm{TMN}=\mathrm{Tptpmn}$

- $16=$ TLL $=$ Tptpll

- $17 \& 18=$ TM2 \& TM1 = Tptpln

- $19=$ PV3 $=$ Tptpv3

- $20=$ PV2a $=$ altered Tptpv2 (altered vitric rocks defined where residual water content $\geq 5$ percent)

- $20.1=$ PV2v $=$ vitric Tptpv2 
- $21=\mathrm{BT} 1 \mathrm{a}=$ altered Tptpv $1 \&$ Tpbt 1

- $21.1=\mathrm{BT} 1 \mathrm{v}=$ vitric Tptpv1 \& Tpbt1

- $22=\mathrm{CHV}=$ vitric $\mathrm{Tac}$

- $23=\mathrm{CHZ}=$ altered (zeolitic) Tac

- $24=\mathrm{BTa}=$ altered Tacbt

- $24.1=\mathrm{BTv}=$ vitric Tacbt

- $25=$ PP4 $=$ Tcpuv

- $26=\mathrm{PP} 3=\mathrm{Tcpuc}$

- $27=\mathrm{PP} 2 \approx \mathrm{T}$ cprn \& Tcplc, 1.c. where residual water content $\geq 5$ percent

- $28=\mathrm{PP} 1 \approx$ Tcplv \& Tcpbt $\&$ Tcbuv, 1.c. where residual water content $<5$ percent

- $29=\mathrm{BF} 3 \approx \mathrm{Tcbuc} \&$ Tcbrn \& Tcblc, 1.c. at lithostratigraphic contact (1.c. of Tcblc)

- $30=\mathrm{BF} 2=$ Tcblv $\&$ Tcbbt $\&$ Tctuv

- $31=\mathrm{TR} 3=\mathrm{Tctuc}$

Differences between HGU picks from DTN: MO0109HYMXPROP.001 [DIRS 155989] are indicated by non-zero values and highlighting in column W. Note that DTN: GS000608314211.003 [DIRS 161658] is listed in the work sheet "borehole data" as corroborating information. HGU picks from this corroboration information are the same as those from DTN: MO0109HYMXPROP.001 [DIRS 155989] except for a sample in Line 132. For that sample, the location identified from DTN: MO0109HYMXPROP.001 [DIRS 155989] is "CCR" while that identified from DTN: GS000608314211.003 [DIRS 161658] is "CUC". However, as indicated above, both "CCR" and "CUC" belong to the same UZ model layer "tcw11." As a result, this difference will not have any effects on estimated UZ-model-layer-averaged rock properties.

Worksheet 'hydroprops'

- Worksheet 'borehole data' is copied and renamed 'hydroprops'

- Columns D, E, F, H, K, M, O-R, U, and W from 'borehole data' are deleted

- Columns G, I, H, K, L, J, and N from 'hydroprops' are copied to columns D to J, respectively

- Saturation values greater than one in column $\mathrm{J}$ are changed to one 
- The logarithm of hydraulic conductivity measurement are collected in column U. Where two hydraulic conductivity measurements were made on the same sample the high pressure permeameter measurement from column $\mathrm{Q}$ is chosen

- Values are copied from column $\mathrm{U}$ to column $\mathrm{V}$

- Rows 62 to 5387 are sorted by column M (HGU)

Worksheet '007 Ks'

- Import DTN: GS990308312242.007 [DIRS 107185] (Busted Butte lab measurements of hydrologic properties)

- The logarithm of hydraulic conductivity is calculated in column J

Worksheet '007 n'

- Import DTN: GS990308312242.007 [DIRS 107185] (Busted Butte lab measurements of physical properties)

Worksheet '98.008 Ks'

- Import DTN: GS990708312242.008 [DIRS 109822] (Busted Butte lab measurements of hydrologic properties)

- The logarithm of hydraulic conductivity is calculated in column G.

Worksheet '98.008 n'

- Import DTN: GS990708312242.008 [DIRS 109822] (Busted Butte lab measurements of physical properties)

Worksheet '006 Ks'

- Import DTN: GS971008312231.006 [DIRS 107184] (ESF surface sample lab measurements of saturated hydraulic conductivity)

Worksheet 'Ksat w ND'

- All columns except F, G, and V from 'hydroprops' are copied to 'Ksat w ND'

- Rows from 62 to 5387 without conductivity values are deleted

- Rows in HGUs without non-detect conductivity measurements (noted as "nf" or "NF") are deleted

- Hydraulic conductivity, SPC \# (i.e., standard Ids for samples), and sample \# are copied from '006 Ks' to HGU \#15 columns O, Q, and R, respectively 
- Rows within each HGU (or group of HGUs as defined above) are sorted by ascending conductivity with non-detects first

- The conductivity for each remaining HGU is ranked in column T

- The rank is converted to a percentile in column U, where percentile equals rank divided by (total number of measurements plus one)

- The NORMSINV function is applied to the percentile in column V. This gives (the value minus the expected value) divided by the standard deviation for that percentile in a normal distribution, which is analogous to plotting the log conductivity values on probability paper

- The intercept and slope of the line fitted through the NORMSINV values (x-axis) and the log conductivity values (y-axis) give the expected value and the standard deviation, respectively, of the log conductivity data and account for the unknown values of the non-detect measurements, which are assumed to be less than the lowest conductivity measured

\section{Worksheet 'Summary'}

Matrix properties for each UZ Model layer are shown. Columns and rows are labeled.

For relative humidity porosity $(\phi(\mathrm{RH}))$, porosity $(\phi)$, saturation $(\mathrm{S})$, bulk density ( $\rho$ bulk), and particle density ( $\rho$ particle), the arithmetic mean, standard deviation, number of samples, and standard error are given. Standard error is standard deviation divided by the square root of number of samples. Minimum and maximum values of saturation are also given. Note: data from only one sample are available for the BTv; these data are consistent with the BT1v, so the BT1v will be used as an analog for the BTv.

Residual saturation $\left(\mathrm{S}_{\mathrm{r}}\right)$, here equal to porosity minus relative humidity porosity, is given in column O. Note: again, BT1v should be used as an analog for the BTv.

For log conductivity, the arithmetic mean, standard deviation, number of samples with a measured conductivity, standard error (the standard deviation divided by the square root of the number of samples with a measured conductivity), and number of non-detect measurements are given in columns $\mathrm{X}$ to $\mathrm{AB}$. Where there are non-detect measurements, these values are shown in red italics. Note: again BT1v should be used as an analog for the BTv.

The mean and standard deviation of the log conductivity data for layers with non-detect measurements (the intercept and slope of the data in worksheet 'Ksat w ND') are shown in columns $\mathrm{AD}$ and $\mathrm{AE}$. The standard error is calculated in column AF as the standard deviation divided by the square root of the total number of conductivity measurements including non-detects.

Log conductivity is converted to log permeability in column AI, where permeability equals conductivity times water viscosity divided by water density and gravity. Permeability is shown 
in column $\mathrm{AH}$. Upscaled log permeability is calculated in column AL, where permeability is upscaled by the factor of 0.38 times the variance. Upscaled permeability is shown in column AK. Note: again BT1v should be used as an analog for the BTv; additionally, BT1a should be used as an analog for the PV2a, and PP1 should be used as an analog for the BF2.

\section{MRC_Q_TCw_fin.xls (Output DTN: LB0207REVUZPRP.002)}

This file was used to develop matrix properties for UZ model layers.

Worksheet '037 wc'

- Import DTN: GS980908312242.037 [DIRS 107180] (ESF North Ramp moisture study borehole sample water retention water content data)

Worksheet '037 wp'

- Import DTN: GS980908312242.037 [DIRS 107180] (ESF North Ramp moisture study borehole sample water retention water potential data)

Worksheet '008 wp \& wc(g per g)'

- Import DTN: GS980408312242.008 [DIRS 107161] (ESF North Ramp moisture study borehole sample water retention data)

Worksheet '040 Ks'

- Import DTN: GS980908312242.040 [DIRS 107169] (ESF North Ramp moisture study borehole sample saturated hydraulic conductivity data)

Worksheet '040 por +'

- Import DTN: GS980908312242.040 [DIRS 107169] (ESF North Ramp moisture study borehole sample physical properties data)

Worksheet '005 bd'

- Import DTN: GS980308312242.005 [DIRS 107165] (ESF North Ramp moisture study borehole sample bulk density data)

Worksheet '005 105n'

- Import DTN: GS980308312242.005 [DIRS 107165] (ESF North Ramp moisture study borehole sample oven dried porosity data)

Worksheet '005 RHn'

- Import DTN: GS980308312242.005 [DIRS 107165] (ESF North Ramp moisture study borehole sample relative humidity oven porosity data) 


\section{Worksheet '008 Kr'}

- Import DTN: GS980408312242.008 [DIRS 107161] (ESF North Ramp moisture study borehole sample relative permeability data)

- Calculate saturation in column $\mathrm{H}$ from water content (column $\mathrm{G}$ ) by assuming the maximum water content for each sample is equal to a saturation of one

- Calculate saturation in column I from water content (column G) by assuming the maximum water content for each sample as measured for the water potential data (worksheet ' $008 w p \& w c(g$ per $g$ )' column $\mathrm{G}$ ) is equal to a saturation of one

- Calculate saturation in column $\mathrm{J}$ from water content (column $\mathrm{G}$ ) by assuming water content equal to the porosity (from either worksheet '040 por +' column G rows 39 to 49 or worksheet '005 $105 n$ ' column B) represents a saturation of one

- Calculate relative permeability in column $\mathrm{K}$ from conductivity (column B) by assuming the maximum conductivity for each sample is equal to a relative permeability of one

- Calculate relative permeability in column L from conductivity (column B) by assuming the saturated conductivity (from worksheet ' $040 \mathrm{Ks}$ ' column B) is equal to a relative permeability of one

Worksheet '039 wc'

- Import DTN: GS980908312242.039 [DIRS 145272] (USW SD-6 water retention water content data)

- Use data from hydroprops.xls worksheet 'borehole data' to make HGU assignments for each sample (column G)

Worksheet '039 wp'

- Import DTN: GS980908312242.039 [DIRS 145272] (USW SD-6 water retention water potential data)

- Use data from hydroprops.xls worksheet 'borehole data' to make HGU assignments for each sample (column G)

Worksheet 'in-situ'

- Copy average, minimum, and maximum in-situ saturation from hydroprops.xls worksheet summary to columns B, C, and D, respectively for HGUs in column A 
- Copy average in-situ water potential from DATAfix_satsum.xls (Wang 2003 [DIRS 161654], SN-LBNL-SCI-003-V2, p. 65; Ahlers 2000 [DIRS 155853], pp. 93 to 94) worksheet 'summary' to column E for HGUs in column A. Note that the averaged data are used for demonstration and not used for calculations. Therefore, they do not have any effect on the determined matrix property

- Dummy values for plotting in column F

Worksheet 'CUC'

1. Import DTN: MO0109HYMXPROP.001 [DIRS 155989] (water retention Hydrologic Properties data from File MRCQ, Worksheet-CUCQ)

2. Assignment of samples to HGU is checked against hydroprops.xls worksheet 'borehole data'

3. Saturation (column D) is (re)calculated assuming the highest measured water content for each sample is equivalent to full saturation

4. Data with water potential values less than approximately 1.4 bars (note: for plotting reasons, water potential is expressed here as a positive number rather than the conventional negative number) that were acquired with a chilled-mirror psychrometer (data from other than borehole USW SD-6 or moisture study boreholes in the ESF North Ramp) are moved to the bottom of columns A to E and are excluded from further use

5. Water content is plotted versus water potential with chilled-mirror psychrometer data shown in open diamond symbols. Each sample is shown in a different color

6. van Genuchten parameters satiated saturation, residual saturation, alpha, $n$, and $m$ are labeled and are at the top of columns $\mathrm{G}$ and $\mathrm{H}$ (note: satiated saturation fixed equal to one; residual saturation is fixed to the value calculated in hydroprops fin.xls 'Summary'; m=1-(1/n))

7. Saturation, $S$, is predicted in column $\mathrm{G}$ based on the measured water potential and the van Genuchten parameters using the following expression, $S=S_{r}+\left(S_{s}-S_{r}\right)\left[1+\left(\alpha P_{c}\right)^{n}\right]^{-m}$

where $S_{r}$ is residual saturation, $S_{s}$ is satiated saturation, $P_{c}$ is water potential, and $\alpha, n$, and $m$ are van Genuchten parameters

8. The squared error (difference) between the predicted saturation and the measured saturation is calculated in column $\mathrm{H}$ and summed in cell $\mathrm{H} 29$

9. The solver function of Excel is used to estimate values for $\alpha$ and $n$ by minimizing the sum of the squared error (cell H29). Note: all optional solver settings are default; where necessary the following constraints are added:

$\alpha \geq 0 \quad n \geq 1$ 
10. Saturation is calculated in column $\mathrm{J}$ based on the van Genuchten water retention function, the estimated parameters, and a range of water potential values in column I. The results are plotted as a red line

11. The Jacobian matrix is calculated numerically in columns $L$ to $M$ using the perturbed parameter values given in cells M26:M28

$J_{i j}=\frac{\partial z_{i}}{\partial p_{j}}$

is an element of the Jacobian matrix where $z_{i}$ is the $i^{\text {th }}$ predicted value (of saturation for this problem), and $p_{j}$ is the $j^{\text {th }}$ parameter. Note because $n$ and $m$ are dependent, Jacobian elements for parameter $n$ are not evaluated

12. The parameter covariance matrix, evaluated in cells P32:Q33, is $\mathbf{C}_{p p}=s_{0}{ }^{2}\left(\mathbf{J}^{T} \mathbf{J}\right)^{-1}$

where $s_{0}{ }^{2}$ is the sum of the squared error divided by the degree of freedom (\# of data points - \# of parameters) and $\mathbf{J}$ is the Jacobian matrix

13. The uncertainty (analogous to the standard error calculated for other hydrologic parameters in hydroprops.xls worksheet 'Summary') of the estimated parameters is calculated in cells P36:P37 as the square root of the diagonal elements of $\mathbf{C}_{p p}$

14. The 95 percent error band (two standard errors) on the fitted van Genuchten curve are calculated in columns $\mathrm{R}$ and $\mathrm{S}$ and plotted as gray lines

\section{Worksheet 'CUL \& $C W$ '}

1. Import DTN: MO0109HYMXPROP.001 [DIRS 155989] (water retention Hydrologic Properties data from File MRCQ, Worksheet-CULQ and Worksheet CWQ). Note that USW UZ-Na7 data are from SEP Table s01144_003 and the UZ-25 and UZ\#16 data from SEP Table s01144_004

1a. Appropriate data from worksheets '039 $w c$ ' and '039 $w p$ ' are added to columns B, $\mathrm{C}$, and $\mathrm{E}$

2. Same as step 2 above

2a. Sample N27 61.9r is not within either the CUL or CW and is removed

3. Same as step 3 above

4. Same as step 4 above

4a. Data with water potential values of 0.0 bars that were acquired with a centrifuge (data from borehole USW SD-6 or moisture study boreholes in the ESF North Ramp) are moved to the bottom of columns A to E and are excluded from further use 
5. Same as step 5 above

5a. Centrifuge data are shown as filled circles. Each centrifuge sample is shown in a different color that is not necessarily different from the colors used for the chilledmirror psychrometer data

6. Same as step 6 above

7. Same as step 7 above

8. Same as step 8 above

9. Same as step 9 above

10. Same as step 10 above

11. Same as step 11 above

12. Same as step 12 above

13. Same as step 13 above

14. Same as step 14 above

15. Average in situ water potential and saturation data from worksheet 'in-situ' is plotted with \pm 2 bar error bars

Worksheet ' $C M W$ '

1. Import DTN: MO0109HYMXPROP.001 [DIRS 155989] (water retention Hydrologic Properties data from File MRCQ, Worksheet-CMWQ)

1a. Appropriate data from worksheets ' $037 w c$ ' and ' $037 w p$ ' are identified by the lithostratigraphy in DTN: LAJF831222AQ98.014 [DIRS 160825] are added to columns $\mathrm{B}, \mathrm{C}$, and $\mathrm{E}$

1b. Appropriate data from worksheet ' $008 w p \& w c(g$ per $g)$ ' are identified as in step 1a above are added to columns $\mathrm{B}, \mathrm{C}$, and $\mathrm{E}$

1c. Appropriate data from worksheets '039 wc' and '039 $w p$ ' are added to columns B, $\mathrm{C}$, and $\mathrm{E}$

2. Same as step 2 above

3. Same as step 3 above

3a. The saturation for the data from 1a is calculated assuming the highest water content from either worksheet '008 $w p \& w c(g$ per $g$ )' or '008 $\mathrm{Kr}$ ' for that sample represents the water content at full saturation 
4. Same as step 4 above

4a. Same as step $4 \mathrm{a}$ above

5. Same as step 5 above

5a. Same as step 5a above

6. Same as step 6 above

7. Same as step 7 above

8. Same as step 8 above

9. Same as step 9 above

10. Same as step 10 above

10a. Plotting the estimated function shows that the shape of the curve does not match well with the data. The parameters ( $\alpha$ and $n$ ) are adjusted by hand to improve the subjective match between the shape of the curve and the data. This adjustment results in an increase of 0.22 ( 9 percent) in the sum of the squared error

11. Same as step 11 above

12. Same as step 12 above

13. Same as step 13 above

14. Same as step 14 above

15. Same as step 15 above

16. Appropriate unsaturated conductivity data from worksheet ' $008 \mathrm{Kr}$ ' are identified as in step la above, added to columns $\mathrm{V}, \mathrm{W}$, and $\mathrm{X}$, and are plotted as circles connected by a dashed line. As in $3 \mathrm{a}$, the saturation is calculated assuming the highest water content measured for the sample represents full saturation (column $\mathrm{W}$ is linked to either column $\mathrm{H}$ or I in ' $008 \mathrm{Kr}$ ')

17. Relative permeability is $k_{r w}=\left(S_{e}\right)^{\eta}\left[1-\left(1-S_{e}^{1 / m}\right)^{n}\right]^{2}$ where $\eta$ and $\mathrm{m}$ are fitting parameters and $S_{e}=\frac{\left(S-S_{r}\right)}{\left(S_{s}-S_{r}\right)}$ saturation. Use of a match point, $\mathrm{S}_{0}$, that is near, but not at, full saturation is recommended to avoid problems with identification of full saturation and large changes in unsaturated conductivity very near saturation due to macropores. Relative permeability can then be redefined in terms of the conductivity at the match point: 
$\frac{K_{w}\left(S_{e}\right)}{K_{w}\left(S_{e, 0}\right)}=\left(\frac{S_{e}}{S_{e, 0}}\right)^{\eta}\left[\frac{1-\left(1-S_{e}^{1 / m}\right)^{m}}{1-\left(1-S_{e, 0}{ }^{1 / m}\right)^{n}}\right]^{2}$

where $S_{e, 0}$ is the effective saturation at the match point and $\mathrm{K}_{\mathrm{w}}\left(\mathrm{S}_{\mathrm{e}, 0}\right)$ is the conductivity at the match point. A saturation match point, $\mathrm{S}_{\mathrm{e}, 0}$, of 0.95 is used for the CMW. The unsaturated conductivity at the match point, $\mathrm{K}_{\mathrm{w}}\left(\mathrm{S}_{\mathrm{e}, 0}\right)$, is calculated in column $\mathrm{Z}$ for each sample by linear interpolation between the nearest saturation and log conductivity data points

18. The redefined relative permeability, left side of last equation in step 17, is calculated in column $\mathrm{Y}$

19. The relative permeability predicted from the saturation data (column W), as expressed on the right side of the last equation in step 17, is calculated in column AA. Parameters $m$ and $S_{r}$ are the same as for the water retention function

20. The squared error (difference) between the predicted relative permeability and the measured relative permeability is calculated in column $\mathrm{AB}$ and summed in cell $\mathrm{AB} 31$

21. The solver function of Excel is used to estimate $\eta$, cell X29, by minimizing the sum of the squared error (cell X23, which is linked to cell AB31). Note: all optional solver settings are default

22. The Jacobian matrix is calculated numerically in column AC using the perturbed $\eta$ value given in cell AC29. The variance and standard error of $\eta$ are calculated in cells AD34 and AE34, respectively

23. Relative permeability is calculated in column $U$ for a range of saturation values in column $\mathrm{T}$. The results are plotted as an orange line

24. The average, minimum, and maximum in-situ saturation are plotted as a gray circle and error bars 


\section{MRC_Q_PTn_fin.xls (Output DTN: LB0207REVUZPRP.002)}

This file was used to develop matrix properties for UZ model layers.

Worksheets 'in-situ', '037 wc', '037 wp', '008 Kr', '040 por +', '005 bd', '005 105n', '005

RHn', '008 wp \& wc(g per g)', '039wc', '039 wp' are prepared as for MRC_Q_TCw_fin.xls with the exception of relative permeability calculations documented in steps 16 - 23 below which are carried out in worksheet ' $008 \mathrm{Kr}$ '.

Worksheets 'CMW', 'BT4', 'TPY', 'BT3', 'TPP', and 'BT2'

1. Import DTN: MO0109HYMXPROP.001 [DIRS 155989] (water retention Hydrologic Properties data from File MRCQ, Worksheet-CNWQ, Worksheet-BT4Q, WorksheetTPYQ, Worksheet-BT3Q, Worksheet-TPPQ, Worksheet-BT2Q,)

1a. Same as step 1a above except that no data are identified for TPY

1b. Same as step $1 \mathrm{~b}$ above except that no data are identified for TPY

1c. Same as step 1c above except that no data are identified for TPY

2. Same as step 2 above. This results in sample UZ16 171.7r begin reassigned from TPY to BT4 and sample SD9 74.1 being removed from BT3 (it is already assigned correctly to $\mathrm{CNW}$ )

3. Same as step 3 above

3a. Same as step 3 a above

4. Same as step 4 above

4a. Same as step $4 \mathrm{a}$ above

5. Water content is plotted vs. water potential on worksheets 'PTn curves' and 'PTn curves (2)' for HGU groups CNW, BT4, and TPY and BT3, TPP, and BT2, respectively, with chilled-mirror psychrometer data shown in open diamond symbols. Each sample is shown in a different color

5a. Centrifuge data are shown as filled circles. Each centrifuge sample is shown in a different color that is not necessarily different from the colors used for the chilled-mirror psychrometer data. Note: no centrifuge data for TPY exist

6. Same as step 6 above

7. Same as step 7 above

8. Same as step 8 above 
9. Same as step 9 above

10. Same as step 10 above. Results are plotted in worksheets 'PTn curves' and 'PTn curves (2)'

11. Same as step 11 above

12. Same as step 12 above

13. Same as step 13 above

14. Same as step 14 above. Results are plotted in worksheets 'PTn curves' and 'PTn curves (2)'

15. Same as step 15 above. Results are plotted in worksheets 'PTn curves' and 'PTn curves (2)'

16. Appropriate unsaturated conductivity data in worksheet ' $008 \mathrm{Kr}$ ' are identified as in step 1a above and are plotted as circles connected by a dashed line in worksheets 'PTn curves' and 'PTn curves (2)'. As in 3a, the appropriate saturation data are identified and highlighted in either column $\mathrm{H}$ or I in ' $008 \mathrm{Kr}$ ' by assuming that the highest water content measured for the sample represents full saturation

17. Same as step 17 above except that the saturation match points are

$\mathrm{CNW}: \mathrm{S} 0=0.85$

BT4: S0 $=0.65$

BT3: $\mathrm{S} 0=0.95$

TPP: S0 $=0.80$

BT2: $\mathrm{S} 0=0.83$

and no relative permeability data for TPY exist

18. Same as step 18 above except the calculation is carried out in worksheet ' $008 \mathrm{Kr}$ ' in column M.

19. Same as step 19 above except the calculation is carried out in worksheet ' $008 \mathrm{Kr}$ ' in column N

20. In worksheet ' $008 \mathrm{Kr}$ ', the squared error (difference) between the predicted relative permeability and the measured relative permeability is calculated in column $\mathrm{X}$ and summed in cells W18:W22 for each of the HGUs identified in cells V18:V22

21. In worksheet ' $008 \mathrm{Kr}$ ', the solver function of Excel is used to estimate $\eta$, cells Z18:Z22, for each HGU identified in cells V18:V22 by minimizing the sum of the 
squared error for the same HGU, cells W18:W22. Note: all optional solver settings are default

22. In worksheet ' $008 \mathrm{Kr}$ ', the Jacobian matrix is calculated numerically in column Y using the perturbed $\eta$ value given in cells AA18:AA22. The variance and standard error of $\eta$ are calculated in cells AB18:AB22 and AC18:AC22, respectively

23. In worksheet ' $008 \mathrm{Kr}$ ', relative permeability is calculated in columns $\mathrm{Q}: \mathrm{U}$ for a range of saturation values in column $P$. The results are plotted as an orange line in worksheets 'PTn curves' and 'PTn curves (2)'

24. The average, minimum, and maximum in situ saturation are plotted as a gray circle and error bars in worksheets 'PTn curves' and 'PTn curves (2)'

\section{MRC_Q_TSW_FIN.XLS (Output DTN: LB0207REVUZPRP.002)}

This file was used to develop matrix properties for UZ model layers.

Worksheets 'in-situ', '037wc', '037 wp', '008 wp \& wc(g per g)', '039 wc', '039 wp' are prepared as for $M R C \_Q_{-} T C w \_$fin.xls.

Worksheet '007 Swp'

- Import DTN: GS990308312242.007 [DIRS 107185] (Busted Butte water retention data)

- Use data from DTN: LA0207SL831372.001 [DIRS 160824] to make HGU assignments for each sample (column F)

Worksheet '007 Ks'

- Import DTN: GS990308312242.007 [DIRS 107185] (Busted Butte hydraulic conductivity data)

Worksheet '007 S K'

- Import DTN: GS990308312242.007 [DIRS 107185] (Busted Butte relative permeability data)

- Use data from DTN: LA0207SL831372.001 [DIRS 160824] to make HGU assignments for each sample (column F)

- In column $\mathrm{G}$, calculate relative permeability from conductivity in column $\mathrm{E}$ assuming the saturated conductivity in worksheet '007 Ks' column $\mathrm{H}$ represents a relative permeability of one. Note: no saturated conductivity measurement for sample INJ-4$16.8 \mathrm{~B}$ exists, so the highest conductivity measured is assumed to equal a relative permeability of one, and relative permeability is calculated in column $\mathrm{H}$ 
Worksheet '99.008 Swp'

- Import DTN: GS990708312242.008 [DIRS 109822] (Busted Butte water retention data)

- Use data from DTN: LA0207SL831372.001 [DIRS 160824] to make HGU assignments for each sample (column G)

Worksheet '99.008 Ks'

- Import DTN: GS990708312242.008 [DIRS 109822] (Busted Butte hydraulic conductivity data)

Worksheet '99.008 S K'

- Import DTN: GS990708312242.008 [DIRS 109822] (Busted Butte relative permeability data)

- Use data from DTN: LA0207SL831372.001 [DIRS 160824] to make HGU assignments for each sample (column G)

- In column $\mathrm{H}$, calculate relative permeability from conductivity in column E assuming the saturated conductivity in worksheet '007 $K s$ ' column $\mathrm{H}$ represents a relative permeability of one

Worksheet '012 wc'

- Import DTN: GS980808312242.012 [DIRS 149375] (USW WT-24 water retention water content data)

- Use data from hydroprops.xls worksheet 'borehole data' to make HGU assignments for each sample (column G)

Worksheet '012 wp'

- Import DTN: GS980808312242.012 [DIRS 149375] (USW WT-24 water retention water potential data)

- Use data from hydroprops.xls worksheet 'borehole data' to make HGU assignments for each sample (column G)

Worksheet '95.008 wc'

- Import DTN: GS950608312231.008 [DIRS 144662] (USW UZ-N27 and UE-25 UZ\#16 water retention water content data). Note: for the most part, these data are already included under DTN: MO0109HYMXPROP.001 [DIRS 155989], however, some additional data under this DTN exist 
Worksheet '95.008 wp'

- Import DTN: GS950608312231.008 [DIRS 144662] (USW UZ-N27 and UE-25 UZ\#16 water retention water potential data). Note: for the most part, these data are already included under DTN: MO0109HYMXPROP.001 [DIRS 155989], however, some additional data under this DTN exist

Worksheets 'TC', 'TR', 'TUL', 'TMN', 'TLL', 'TM2 \& TM1', 'PV3', 'PV2a', and 'PV2v'

1. Import DTN: MO0109HYMXPROP.001 [DIRS 155989] (water retention Hydrologic Properties data from File MRCQ, Worksheet-TCQ, Worksheet-TRQ, WorksheetTULQ, Worksheet-TMNQ, Worksheet-TLLQ, Worksheet-TM2Q, Worksheet-TM1Q, Worksheet-PV3Q, Worksheet-PV2Q). Note: Data from Worksheet-TM2Q and Worksheet-TM1Q are combined in worksheet 'TM2 \& TM1'

1a. Appropriate data from worksheets ' $037 w c$ ' and ' $037 w p$ ' are identified by the lithostratigraphy in DTNs: LAJF831222AQ98.014 [DIRS 160825] and GS960908314224.020 [DIRS 106059] (columns B, C, and E of worksheets ' $T C$ ' and 'TR'). ESF station of contacts from Table 2 in Geology of the Exploratory Studies Facility Topopah Spring Loop (CRWMS M\&O 1998 [DIRS 102679]) are used to confirm the lithostratigraphy information provided in the above two DTNs

1b. Appropriate data from worksheet ' $008 w p \& w c(g$ per $g)$ ' are identified as in step la above are added to columns B, C, and E of worksheet ' $\mathrm{TC}$ '

1c. Appropriate data from worksheets '039 $w c$ ' and '039 $w p$ ' are added to columns B, $\mathrm{C}$, and $\mathrm{E}$ of worksheets 'TC', 'TR', 'TM2 \& $T M 1$ ', and ' $P V 3$ '

1d. Appropriate data from worksheets '007 $S w p$ ' and '99.008 $S w p$ ' are added to columns B, D, and $\mathrm{E}$ of worksheet ' $P V 2 v$ '

1e. Appropriate data from worksheets ' $012 w c$ ' and ' $012 w p$ ' are added to columns B, $\mathrm{C}$, and $\mathrm{E}$ of worksheet ' $P V 2 a$ '

1f. Appropriate data from worksheets '95.008 $w c$ ' and '95.008 $w p$ ' are added to columns $\mathrm{B}, \mathrm{C}$, and $\mathrm{E}$ of worksheets 'TLL' and ' $P V 3$ '

2. Same as step 2 above

2a. Sample SD9-1440.5r is not within the PV2 and is removed

3. Same as step 3 above except for worksheet ' $P V 2 v$ ' where data are given in terms of saturation rather than water content

4. Same as step 4 above

4a. Same as step $4 \mathrm{a}$ above 
5. Same as step 5 above

5a. Same as step 5a above

6. Same as step 6 above

7. Same as step 7 above

8. Same as step 8 above

9. Same as step 9 above

10. Same as step 10 above

10a. Plotting the estimated function for PV3 shows that the shape of the curve does not match well with the data. The parameters $(\alpha$ and $n)$ are adjusted by hand to improve the subjective match between the shape of the curve and the data. This adjustment results in an increase of 0.14 (16 percent) in the sum of the squared error

11. Same as step 11 above

12. Same as step 12 above

13. Same as step 13 above

14. Same as step 14 above

15. Same as step 15 above

16. In worksheet ' $P V 2 v$ ' only, appropriate unsaturated conductivity data from worksheets '007 $S K$ ' and ' $99.008 S K$ ' are identified as in step 1d above, added to columns $\mathrm{V}, \mathrm{W}$, and $X$, and are plotted as circles connected by a dashed line

17. In worksheet ' $P V 2 v$ ' only, same as step 17 under spreadsheet $M R C \_Q \_T C w$ fin.xls, worksheet ' $C M W$ ', except $\mathrm{Se}, 0=0.9$

18. In worksheet ' $P V 2 v$ ' only, same as step 18 under spreadsheet $M R C \_Q \_T C w \_f i n . x l s$, worksheet ' $C M W$ '

19. In worksheet ' $P V 2 v$ ' only, same as step 19 under spreadsheet $M R C \_Q \_T C w \_$fin.xls, worksheet ' $C M W$ '

20. In worksheet ' $P V 2 v$ ' only, same as step 20 under spreadsheet $M R C \_Q \_T C w$ fin.xls, worksheet ' $C M W$ '

21. In worksheet ' $P V 2 v$ ' only, same as step 21 under spreadsheet $M R C \_Q \_T C w \_f i n . x l s$, worksheet ' $C M W$ ' 
22. In worksheet ' $P V 2 v$ ' only, same as step 22 under spreadsheet $M R C_{-} Q_{-} T C w_{-}$fin.xls, worksheet ' $C M W$ '

23. In worksheet ' $P V 2 v$ ' only, same as step 23 under spreadsheet $M R C \_Q \_T C w \_$in.xls, worksheet ' $C M W$ '

24. In worksheet ' $P V 2 v$ ' only, same as step 24 under spreadsheet $M R C \_Q \_T C w \_$fin.xls, worksheet ' $C M W$ '

\section{MRC_Q_CHCF_FIN.XLS (Output DTN: LB0207REVUZPRP.002)}

This file was used to develop matrix properties for UZ model layers.

Worksheets 'in-situ', '039 wc', '039 wp', '007 $S$ wp', '007 Ks', '007 $S \mathrm{~K}$ ', '99.008 $S$ wp', '99.008 Ks', '99.008 S K', '012 wc', '012 wp', '95.008 wc', and '95.008 wp' are prepared as for MRC_Q_TSw_fin.xls.

Worksheet '001 wc wp'

- Import DTN: GS010608312242.001 [DIRS 160822] (Busted Butte water retention data)

- Use data from DTN: LA0207SL831372.001 [DIRS 160824] to make HGU assignments for each sample (column F)

Worksheet '001 wc K'

- Import DTN: GS010608312242.001 [DIRS 160822] (Busted Butte relative permeability data)

- Use data from DTN: LA0207SL831372.001 [DIRS 160824] to make HGU assignments for each sample (column G)

- In column I, calculate the saturation from water content in column D assuming that the highest water content listed for the same sample in worksheet '001 $w c w p$ ' (if measured) is the water content at full saturation

- In column J, calculate the saturation from water content in column D assuming the highest water content listed for each sample is the water content at full saturation

- In column $\mathrm{K}$, calculate relative permeability from conductivity in column $\mathrm{E}$ assuming the highest conductivity for each sample is the saturated conductivity

Worksheet '96.003 wp wc'

- Import DTN: GS960808312231.003 [DIRS 147590] (USW SD-7, USW SD-9, USW SD-12, and UE-25 UZ\#16 water retention data). Note: for the most part, these data are already included under DTN: MO0109HYMXPROP.001 [DIRS 155989], however, are some additional data under this DTN exists 
Worksheets 'BT1v', 'BT1a', 'CHV', 'CHZ', 'BTv', 'BTa', 'PP4', 'PP3', 'PP2', 'PP1', 'BF3', and 'BF2'

1. Import DTN: MO0109HYMXPROP.001 [DIRS 155989] (water retention Hydrologic Properties data from File MRCQ, Worksheet-BT1aQ, Worksheet-CHZQ, WorksheetBTQ, Worksheet-PP4Q, Worksheet-PP3Q, Worksheet-PP2Q, Worksheet-PP1Q, Worksheet-BF3Q, Worksheet-BF2Q). Note: Data from Worksheet-BTQ are assigned to HGU BTa; no data are identified in this DTN for HGUs BT1v, CHV, and BTv

1a. Appropriate data from worksheets ' $039 w c$ ' and '039 $w p$ ' are added to columns B, $\mathrm{C}$, and $\mathrm{E}$ of worksheets ' $B T 1 v$ ', ' $C H V$ ', 'BTv', 'PP4', 'PP3', and 'BF3'

1b. Appropriate data from worksheet ' $99.008 S \mathrm{wp}$ ' are added to columns B, D, and E of worksheets 'BT1v' and 'CHV'

1c. Appropriate data from worksheet '007 $S w p$ ' are added to columns B, D, and E of worksheet 'BT1v'

1d. Appropriate data from worksheets '001 wc wp' are added to columns B, C, and E of worksheets 'BT1v' and ' $\mathrm{CHV}$ '

1e. Appropriate data from worksheets ' $012 w c$ ' and ' $012 w p$ ' are added to columns B, $\mathrm{C}$, and $\mathrm{E}$ of worksheets 'BTla' and ' $\mathrm{CHZ}$ '

1f. Appropriate data from worksheets '95.008 $w c$ ' and '95.008 $w p$ ' are added to columns $\mathrm{B}, \mathrm{C}$, and $\mathrm{E}$ of worksheets ' $\mathrm{CHZ}$ ', 'PP4', 'PP2', and ' $P P 1$ '

$1 \mathrm{~g}$ Appropriate data from worksheet '96.003 wc wp' are added to columns B, C, and E of worksheet ' $\mathrm{CHV}$ '

2. Same as step 2 above

2a. Sample SD9-1440.5r, which was not within PV2 (see step 2a above) is within the BT1v and is added

3. Same as step 3 above except for data from worksheets '007 $S w p$ ' and '99.008 $S w p$ ' where data are given in terms of saturation rather than water content

3a. The saturation for the data from $1 \mathrm{~d}$ is calculated assuming that the highest water content from either worksheet ' $001 w c w p$ ' or ' $001 w c K$ ' for that sample represents the water content at full saturation

4. Same as step 4 above

4a. Same as step 4a above

5. Same as step 5 above

5a. Same as step 5a above 
6. Same as step 6 above

7. Same as step 7 above

8. Same as step 8 above

9. Same as step 9 above

10. Same as step 10 above

10a. Plotting the estimated function for PP4 shows that the shape of the curve does not match well with the data. The parameters $(\alpha$ and $n)$ are adjusted by hand to improve the subjective match between the shape of the curve and the data. This adjustment results in an increase of 0.951 (65 percent) in the sum of the squared error

11. Same as step 11 above

12. Same as step 12 above

13. Same as step 13 above

14. Same as step 14 above

15. Same as step 15 above

16. In worksheets ' $B T 1 v$ ' and ' $C H V$ ' only, appropriate unsaturated conductivity data from worksheets '99.008 $S K$ ', '007 $S K$ ', and '001 wc $K$ ' are identified as in steps $1 \mathrm{~b}, 1 \mathrm{c}$, and $1 \mathrm{~d}$ above, added to columns $\mathrm{V}, \mathrm{W}$, and $\mathrm{X}$, and are plotted as circles connected by a dashed line

16a. As in step $3 a$ above, the saturation for the data from ' $001 w c K$ ' is calculated assuming that the highest water content from either worksheet '001 $w c w p$ ' or '001 wc $K$ ' for that sample represents the water content at full saturation

17. In worksheets 'BTlv' and ' $C H V$ ' only, same as step 17 above

18. In worksheets ' $B T 1 v$ ' and ' $C H V$ ' only, same as step 18 above

19. In worksheets ' $B T 1 v$ ' and ' $C H V$ ' only, same as step 19 above

20. In worksheets ' $B T 1 v$ ' and ' $C H V$ ' only, same as step 20 above

21. In worksheets 'BT1v' and ' $C H V$ ' only, same as step 21 above

22. In worksheets ' $B T 1 v$ ' and ' $C H V$ ' only, same as step 22 above

23. In worksheets ' $B T 1 v$ ' and ' $C H V$ ' only, same as step 23 above

24. In worksheets ' $B T 1 v$ ' and ' $C H V$ ' only, same as step 24 above 


\section{vG_Summary_fin.xls (Output DTN: LB0207REVUZPRP.002)}

This file was used to develop matrix properties for UZ model layers.

Note: This spreadsheet contains links to hydroprops_fin.xls, MRC_Q_TCw_fin.xls, $M R C \_Q \_P T n \_$fin.xls, MRC_Q_TSw_fin.xls, and $M R C \_Q \_C H C F$ fin.xls; these spreadsheets must be open at the same time this spreadsheet is open.

Worksheet 'vG Summary'

Values shown in columns C, D, E, G, H, and J are linked to the spreadsheets (above) where they are estimated.

Values of $\eta$ and $\sigma_{\eta}$ (columns L and M) for CMW, CNW, BT4, BT3, TPP, BT2, PV2v, BT1v, and $\mathrm{CHV}$ are those estimated by fitting relative permeability data. Other values of $\eta$ and $\sigma_{\eta}$ are estimated as

$$
\eta=A m-B \log (k)+C
$$

and

$\sigma_{\eta}=\left(A+\sigma_{A}\right) m-\left(B+\sigma_{B}\right) \log (k)+\left(C+\sigma_{C}\right)-\eta$

where $m$ is the van Genuchten parameter, $k$ is upscaled permeability, and $A, B$, and $C$ are fitting parameters. Note: the minus sign before $B$ is because $\eta$ is correlated to $\log \left(k^{-1}\right)$. The fitting parameters are estimated in worksheet 'fitted kr'.

\section{Worksheet 'fitted kr'}

For each layer, column A, where $\eta$, column $\mathrm{D}$, has been estimated from relative permeability data, the estimates of upscaled permeability, column B, and the van Genuchten parameter $m$, column $\mathrm{C}$, are given.

The parameter $\eta$ is predicted in column $\mathrm{E}$ using the equation given above and the parameters in cells F1:F3. The squared difference between the two values of $\eta$ is calculated in column $\mathrm{F}$ and summed in cell F4.

The Jacobian matrix (see step 11 under spreadsheet $M R C_{-} Q_{-} T C w_{-}$fin.xls worksheet CUC) is calculated in columns $G$ to I using the perturbed parameter values in cells G1:G3. The covariance matrix (see step 12 under spreadsheet $M R C \_Q_{-} T C w_{-}$fin.xls worksheet CUC) is calculated in cells K5:M7. The standard error (see step 13 under spreadsheet $M R C \_Q$ _ $C w \_$fin.xls worksheet CUC) is calculated in cells $\mathrm{K} 1: \mathrm{K} 3$. The parameter values perturbed by one standard error are given in cells N1:N3.

\section{lecan97.xls (Output DTN: LB0408REVUZPRP.001)}

This file was used for estimating fracture parameters.

In this spreadsheet, only the workbook "New Layers" was used to calculated fracture permeability for UZ model layers that have been documented in the Model Report. Therefore, the documentation is limited to this workbook. 
In this spreadsheet, columns A, B, and C contain data from DTN: GS960908312232.013 [DIRS 105574]. Column D corresponds to log of air permeability calculated from column C. Columns H, I, J contain total number of air k measurements, average of log of air permeability and standard deviation of $\log$ (air permeability) for each geologic unit within a single borehole, respectively. Columns L, M, N contain total number of air k measurements, average of log of air permeability and standard deviation of $\log$ (air permeability) for each geologic unit for the boreholes, respectively.

\section{UTCA_BRFA.xls (Output DTN: LB0408REVUZPRP.001)}

This file was used for estimating fracture parameters.

This spreadsheet contains two notebooks UPCA and UTCA_BRFA. In UPCA, columns A-E contain data from Alcove 3 (DTN: GS970183122410.001 [DIRS 105580]). Column F corresponds to $\log$ of air permeability calculated from column C. Columns H, I and J contain total number of air k measurements, average of $\log$ of air permeability and standard deviation of $\log$ (air permeability) for each geologic unit within a single borehole (labeled as "location"), respectively. Columns $\mathrm{M}, \mathrm{N}$ and $\mathrm{O}$ contain total number of air k measurements, average of log of air permeability and standard deviation of $\log$ (air permeability) for each geologic unit for the boreholes, respectively.

In UTCA_BRFA, columns C-E contain data from Alcove 1 (DTN: GS970183122410.001 [DIRS 105580]). Column F corresponds to log of air permeability calculated from column E. Columns H, I, J, K contain total number of air k measurements, geometric mean of air $\mathrm{k}, \log$ of geometric mean of air permeability and standard deviation of $\log$ (air permeability) for each geologic unit within a single borehole (labeled as "location"), respectively. Columns V, W and X contain total number of air k measurements, average of log of air permeability and standard deviation of $\log$ (air permeability) for each geologic unit for the boreholes, respectively.

\section{drift.xls (Output DTN: LB0408REVUZPRP.001)}

In this spreadsheet, column D contains air permeability data from DTNs: LB970600123142.001 [DIRS 105589], LB980120123142.004 [DIRS 105590], LB980120123142.005 [DIRS 114134], and LB960500834244.001 [DIRS 105587]. Column E corresponds to log of permeability values calculated from column D. Columns $\mathrm{J}$ and $\mathrm{K}$ contain total number of air permeability measurements, geometric mean of $\log$ of air permeability and standard deviation of $\log$ (air permeability), respectively.

\section{airk.xls (Output DTN: LB0408REVUZPRP.001)}

This file was used for estimating fracture parameters.

Since the equations used in the spreadsheet are simple standard functions of MS Excel, the supplementation needed here is a description of the specific cells that contain the input, output and calculation used in the spreadsheet application. A description of the equations is provided. This spreadsheet is linked to lecan97.xls, drift.xls and UTCA_BRFA.xls that discussed above. 
In this spreadsheet, only the workbook "New Layers" was used to calculated fracture permeability for UZ model layers that has been documented in the Model Report. Therefore, the documentation is limited to this workbook. This spreadsheet calculates layer-averaged fracture permeability information based on air $\mathrm{k}$ data contained in lecan97.xls, UTCA_BRFA.xls and drift.xls.

In the workbook "New Layers", columns A, B, C, and D contain model layer name, total number of air k measurements from different sources, mean of $\log$ (air permeability), and the standard deviation of $\log$ (air permeability), respectively.

To demonstrate the calculation procedure, model layer tcw12 is used as an example. In this discussion subscripts 1, 2, 3 refer to data from Lecan97.xls, UTCA (UTCA_BRFA.xls) and UPCA (UTCA_BRFA.xls), respectively.

1. Cell B5 contains the total number of measurements, denoted by $\mathrm{N}$, which was calculated as follows: Cells J4-J6 contain the number of measurements from the three data sources $\left(\mathrm{N}_{1}, \mathrm{~N}_{2}\right.$ and $\left.\mathrm{N}_{3}\right)$, respectively, by linking with the relevant cells in lecan97.xls and UTCA_BRFA.xls). The total number is given in Cell $\mathrm{J} 7$ calculated by

$\mathrm{N}=\mathrm{N}_{1}+\mathrm{N}_{2}+\mathrm{N}_{3}$

The value in Cell $\mathrm{J} 7$ was then assigned to B5

2. Cell $\mathrm{C} 5$ contains the mean of $\log$ (air permeability) $\left(\mathrm{X}_{\mathrm{m}}\right)$ that was calculated as follows: Cells K4-K6 contain the means from the three data sources $\left(\mathrm{X}_{\mathrm{m} 1}, \mathrm{X}_{\mathrm{m} 2}\right.$ and $\left.\mathrm{X}_{\mathrm{m} 3}\right)$, respectively, by linking with the relevant cells in lecan97.xls and UTCA_BRFA.xls. Values in cells P4-P6 are calculated as $\mathrm{N}_{1} \mathrm{X}_{\mathrm{m} 1}, \mathrm{~N}_{2} \mathrm{X}_{\mathrm{m} 2}$, and $\mathrm{N}_{3} \mathrm{X}_{\mathrm{m} 3}$. Cell P7 summates values in the three cells. Then, the mean $X_{m}$ was stored in cell $\mathrm{K} 7$ and calculated by

$\mathrm{X}_{\mathrm{m}}=\left(\mathrm{N}_{1} \mathrm{X}_{\mathrm{m} 1}+\mathrm{N}_{2} \mathrm{X}_{\mathrm{m} 2}+\mathrm{N}_{3} \mathrm{X}_{\mathrm{m} 3}\right) / \mathrm{N}=($ the value in cell $\mathrm{P} 7) /($ the value in cell $\mathrm{J} 4)$

The value in $\mathrm{K} 7$ was assigned to $\mathrm{C} 5$

3. Cell D5 contains standard deviation of $\log ($ air permeability) $(\sigma)$ that was calculated as follows: Cells L4-L6 contain the standard deviation values from the three data sources $\left(\sigma_{1}, \sigma_{2}\right.$ and $\left.\sigma_{3}\right)$, respectively, by linking with the relevant cells in lecan97.xls and UTCA_BRFA.xls. Variances in cells N4-N6 $\left(\sigma_{1}{ }^{2}, \sigma_{2}{ }^{2}\right.$ and $\left.\sigma_{3}{ }^{2}\right)$ were then calculated from cells L4-L6. Cells Q4 was calculated by

$$
\frac{\left(N_{1} X_{1 m}\right)^{2}+\sigma_{1}^{2} N_{1}\left(N_{1}-1\right)}{N_{1}}=\sum_{i=1}^{N_{1}} x_{i}^{2}
$$

where $\mathrm{x}_{\mathrm{i}}$ refers to $\log$ (air permeability) for measurement i. Similar calculations were performed for the other two data sources. Cell Q7 summates values in the three cells 
Q4-Q6. The value in Q7 corresponds to

$$
\sum_{i=1}^{N} x_{i}^{2}
$$

where $\mathrm{N}$ is the total number of measurements from the three data sources. If using the cell names to represent values in them, N7 was calculated as

$$
N 7=\frac{J 7 Q 7-(P 7)^{2}}{J 7(J 7-1)}=\frac{N \sum_{i=1}^{N} x_{i}^{2}-\left(N X_{m}\right)^{2}}{N(N-1)}=\frac{\sum_{i=1}^{N}\left(x_{i}-X_{m}\right)^{2}}{N-1}
$$

By definition, N7 is the overall variance of $\log$ (air permeability) for air $\mathrm{k}$ data from the three data sources. L7 contains the corresponding standard deviation calculated from N7. Its value was assigned to D5.

A similar procedure was used for the model layers that have measurement from different sources. If a model layer only has data from a single source (lecan97.xls, drift.xls, and UTCA_BRFA.xls), the above calculation procedure was not needed. The relevant value can be directly obtained from the data source. Also in the spreadsheet, some standard deviation values were assigned to model layers that only contain one measurement. These values were not used

\section{Fpor.xls (Output DTN: LB0408REVUZPRP.001)}

This file was used for estimating fracture parameters.

'Sheet 1' contains fracture porosity values calculated from other sources (Section 6.1.3.4). The input sources and calculations are explicitly indicated in the workbook.

In 'sheet 2', Column A contains names of UZ model layers and Column $\mathrm{C}$ contains the corresponding aperture values (output DTN: LB0205REVUZPRP.001). Column E contains van Genuchten $\alpha$ calculated using Equation 6-9. Column G contains fracture intensity or frequency values (DTN: LB990501233129.001 [DIRS 106787]). Column I contains fracture porosity values calculated from Equation 6-12. Column $M$ contains $\log (\alpha)$ values. Below Row 32 was used for estimating fracture porosity for tsw34. The input sources and calculations are explicitly indicated in the workbook for this estimation. 


\section{INTENTIONALLY LEFT BLANK}

